\title{
Synthesis Characterization and Antibacterial, Antifungal Activity of N-(Benzyl Carbamoyl or Carbamothioyl)-2-hydroxy Substituted Benzamide and 2-Benzyl Amino-Substituted Benzoxazines
}

\author{
Tyson Belz, Saleh Ihmaid, Jasim Al-Rawi, and Steve Petrovski \\ School of Pharmacy and Applied Science, La Trobe University, P.O. Box 199, Bendigo, UIC 3552, Australia
}

Correspondence should be addressed to Jasim Al-Rawi; j.al-rawi@latrobe.edu.au

Received 17 June 2013; Revised 8 August 2013; Accepted 11 August 2013

Academic Editor: Armando Rossello

Copyright (C) 2013 Tyson Belz et al. This is an open access article distributed under the Creative Commons Attribution License, which permits unrestricted use, distribution, and reproduction in any medium, provided the original work is properly cited.

New N-(benzyl carbamothioyl)-2-hydroxy substituted benzamides 13, 20, and 21 were synthesized using sodium bicarbonate and benzyl amine with 2-thioxo-substituted-1,3-benzoxazines 6, 10a, b, 11c, and 12a-n. The 2-thioxo-substituted-1,3-oxazines 6, 10ab, 11d 12a-n, and 26 were converted to the corresponding 2-methylthio-substituted-1,3-oxazines $\mathbf{1 4 a}-\mathbf{l}$ and 24 which were then converted to 2-benzyl amino-substituted-benzoxazines $\mathbf{1 5 a - i}$ by refluxing with benzylamine. Products $\mathbf{1 5 a}, \mathbf{b}, \mathbf{e}, \mathbf{f}$, and $\mathbf{g}$ were also synthesized by boiling the corresponding $\mathrm{N}$-(benzyl carbamothioyl)-2-hydroxy substituted benzamides $\mathbf{1 3} \mathbf{a}, \mathbf{b}, \mathbf{f}, \mathbf{1}$, and $\mathbf{m}$ in acetic acid. 2-Oxo-substituted-1,3-benzoxazines 22 and 25 were prepared by treating the corresponding 2-methylthio-substituted-1,3oxazines 14 and 24 with dilute $\mathrm{HCl}$. The N-(benzyl carbamoyl)-2-hydroxy substituted benzamide $\mathbf{2 3}$ was synthesized from the reaction of 2-oxo-substituted-1,3-benzoxazine 22 with benzylamine. The new products were characterized using IR, ${ }^{1} \mathrm{H}$, and ${ }^{13} \mathrm{C}$ NMR in addition to microanalysis. Selected compounds were tested in vitro for antibacterial and antifungi activity and the most active compounds were found to be the 4-(substituted-benzylamino)-2-hydroxy benzoic acids 9a and d (M. chlorophenolicum, MIC 50 and $25 \mu \mathrm{gm} \mathrm{L} \mathrm{L}^{-1}$, resp.), N1, N3-bis (benzyl carbamothioyl)-4,6-dihydroxy-substituted phthalamides 20a and 20c (B. subtilis MIC $12.5,50 \mu \mathrm{gm} \mathrm{L}^{-1}$, resp.) and 21 (M. chlorophenolicum, MIC $50 \mu \mathrm{gm} \mathrm{L}^{-1}$ ).

\section{Introduction}

The search for new antibacterial compounds is a challenging task as bacteria are continuously developing resistance to antimicrobial compounds; however, infections due to such bacterial strains are infrequent although potentially fatal [13]. This ongoing problem has resulted in the search for newer, more effective antibacterial compounds [1-3].

Urea, thiourea $3(\mathrm{X}=\mathrm{O}$ or $\mathrm{S})$, and benzo-1,3-oxazine compounds $\mathbf{5}$ and $\mathbf{6}$ (Scheme 1) have been shown to possess antibacterial and antifungal properties [4-11]. The benzyl thiourea analogue 3 has been reported to show activity against Gram-positive bacteria [12].

The N-benzoyl-2-hydroxybenzamides [13] are important pharmacophores for antibacterial activity in which the 2hydroxy group (hydrogen bonding donor) contributes to the activity, the imide linker (preferred) or urea linker retains activity and free $\mathrm{NH}$ is required for high activity.
The Topliss method [14] was used in the optimization of salicylic acid derivatives for potential use as antibacterial agents. The employment and analysis of physicochemical parameters and molecular electronic surfaces which highlight the electronic, lipophilic, and steric features may be useful guidelines in the continuous search for new, more effective 3 -amino-salicylic acid analogs. The synthesis of the urea or thiourea product (3, Scheme 1 ) was previously achieved from the reaction of benzoylisocyanate or benzoylisothiocyanate 1 (X=O or S, resp.) with amines 2 [15-17].

The substitution $\mathrm{R}$ on the aromatic ring could be alkyl, alkoxy, $-\mathrm{OC}=\mathrm{OCH}_{3}$ in positions $2,3,4,5$, and 6 , and the $\mathrm{R}_{1}-\mathrm{N}-\mathrm{R}_{2}$ in product 3 could be aliphatic, aromatic, or cyclic amine substitutions. Limitation associated with this method is that $\mathrm{R}$, the substitution on the aromatic ring, cannot be $-\mathrm{OH}$ or $\mathrm{RN}-$, which is desirable for antimicrobial activity, particularly the hydroxy group [18]. 
Furthermore, the synthesis of 2-amino-substituted-1,3benzoxazine 5 was achieved through the reaction of the corresponding amine 2 with ethyl 2-cyanobenzoate 4 [19-21]. However, again the limitation in this method is that the $\mathrm{R}$ in product 5 cannot be $-\mathrm{OH}$ or $-\mathrm{NH}_{2}$.

The reaction of substituted 2-thio-1,3-benzoxazine-4-one 6 (Scheme 1) with primary and secondary amines showed considerable interest in the literature.

The secondary amine $\mathbf{2}$ (dimethyl, diethyl, and cyclic amines) reaction with 2-thioxo-2,3-substituted 1,3-benzoxazin-4-one 6 gave only 2-amino-substituted-1,3-benzoxazine 5 [19, 20, 22, 23]. Reactions with primary amines lead to the opening of the oxazine ring and produce thiourea type analogues (compound $3 \mathrm{R}=2-\mathrm{OH}$ and $\mathrm{R}_{1} \mathrm{NR}_{2}=-\mathrm{HN}-$ alkyl) while with $\mathrm{NH}_{2} \mathrm{CH}_{2} \mathrm{Ph}$ gave $3 \mathrm{R}=2-\mathrm{OH}$ and $\mathrm{R}_{1} \mathrm{NR}_{2}$ $=\mathrm{NHCH}_{2} \mathrm{Ph}$ mixed with 2-(benzyl amino)-4H-benz $[e]-1,3-$ oxazin-4-one $\left(5 \mathrm{R}=\mathrm{H}\right.$ and $\mathrm{R}_{1} \mathrm{NR}_{2}=-\mathrm{NHCH}_{2} \mathrm{Ph}[19,20]$. The above reaction produced low yields or a mixture of products 13a and 15a (Scheme 2) which was difficult to separate.

In this work, we developed simple general procedures for the synthesize of $\mathrm{N}$-(benzyl carbamothioyl)-2-hydroxybenzamides 13, 20, and 21, N-(benzyl carbamoyl)-2-hydroxysubstituted-benzamides 23, and 2-(benzyl amino)-substituted-1,3-benzoxazin-4-one $\mathbf{1 5}$ and 26. The antibacterial and antifungal activity was evaluated for a number of these products with the intension of producing novel products that can be used to eliminate problematic bacteria in the environmental and medical settings. These compounds could potentially result in novel antibiotic.

\section{Results and Discussion}

\subsection{Chemistry}

2.1.1. Synthesis of Substituted 2-Hydroxy Aromatic Carboxylic Acids. 5-Substituted-4,6-dihydroxybenzene-1,3-dicarboxylic acids 16a-c, and 2,3-dihydroxybenzene-1,4-dicarboxylic acid 17 were prepared by carboxylation of 2-substituted-1,3hydroxy-benzene and 1,2-dihydroxy-benzene, respectively, according to the previously reported method [24]. Compound 7 was selectively acetylated in the presence of $\mathrm{NaOH}$ and acetic anhydride with the reaction maintained at $\mathrm{pH}$ 6-7 in accordance with the reported procedure [25-27] to give the acid 8a an excellent yield (82\%) (Scheme 2).

Allowing compound 7 to react with substituted benzaldehyde gave the corresponding Schiff base $\mathbf{8 b}$-c (Scheme 2) [28-33]. Reduction of Schiff base $\mathbf{8 b}$-c with sodium borohydride gave 4-(substituted-benzylamino)-2-hydroxybenzoic acids $9 \mathbf{a}-\mathbf{c}$ with high yield (73-85\%). The structures of the prepared acids were confirmed using mp, IR, ${ }^{1} \mathrm{H}$, and ${ }^{13}$ CNMR which was in good agreement with the previously reported physical and spectroscopy data [26-28].

2.1.2. Synthesis of Substituted 2-Thio-substituted-benzoxazines. The 2-thio-substituted-1,3-benzoxazines 6, 10, 11, 12 (a R $=8-\mathrm{CH}_{3}, \mathbf{b} \mathrm{R}=8-\mathrm{Ph}, \mathbf{c} \mathrm{R}=6-\mathrm{Br}, \mathbf{d} \mathrm{R}=6-\mathrm{OCH}_{2} \mathrm{CH}_{3}, \mathbf{e}$ $\mathrm{R}=7-\mathrm{OCH}_{2} \mathrm{CH}_{3}$, f $\mathrm{R}=8-\mathrm{OCH}_{2} \mathrm{CH}_{3}, \mathbf{g ~ R}=6-\mathrm{OCH}_{3}, \mathbf{h}$ $\mathrm{R}=7-\mathrm{OCH}_{3}$, i $\mathrm{R}=8-\mathrm{OCH}_{3}, \mathbf{j} \mathrm{R}=6,8-\mathrm{I}, \mathbf{k} \mathrm{R}=7-\mathrm{OH}$,
$1 \mathrm{R}=7-\mathrm{OH},-8-\mathrm{CH}_{3}$, and $\left.\mathbf{m} \mathrm{R}=8-\mathrm{OH}\right), \mathbf{1 8}$, and 19 were synthesized from the reaction of the substituted 2-hydroxy benzoic acid with freshly prepared $\mathrm{Ph}_{3} \mathrm{P}(\mathrm{SCN})_{2}$ (Schemes 2 and 3 ) following the reported conditions [22,34] with some modifications (see Experimental). It is worth noting that the reaction of 4-benzylideneamino-2-hydroxybenzoic acid $\mathbf{8 d}$ formed the corresponding 7-(benzylidene)amino-2-thio-1,3benzoxazines which were hydrolysed during the isolation of the product and gave 7-amino-2-thio-1,3-benzoxazines $\mathbf{1 0 b}$. However, the reaction of 4-amino-2-hydroxybenzoic acid 7 with the freshly prepared $\mathrm{Ph}_{3} \mathrm{P}(\mathrm{SCN})_{2}$ failed to produce the expected product $\mathbf{1 0 b}$ however gave a complex, unidentifiable molecule containing a triphenylphosphene group attached to the oxazine product.

7-(Substituted benzylamino)-2-thioxo-2,3-dihydro- $4 \mathrm{H}$ 1,3-benzoxazin-4-one 11a-c were synthesized from the reaction of 4-(substituted-benzylamino)-2-hydroxybenzoic acids $9 a-c$ with the freshly prepared $\mathrm{Ph}_{3} \mathrm{P}(\mathrm{SCN})_{2}[22,32]$ (Scheme 2). The structures of the new products 11a-c were confirmed using ${ }^{1} \mathrm{H}$, and ${ }^{13} \mathrm{CNMR}$ and microanalysis.

Similarly, the substituted-2-thioxo-1,3-benzoxazin-4-one $\mathbf{6}$ and $\mathbf{1 2 b}-\mathbf{n}$ prepared using a previously reported [22, $23,33]$ method gave products with identical physical and spectroscopic data.

The benz-bis-(1,3-oxazine) $\mathbf{1 8 a - c}$ and 19 were prepared from the reaction of dihydroxy-dicarboxybenzoic acids 16a-c and 17 with the freshly prepared $\mathrm{Ph}_{3} \mathrm{P}(\mathrm{SCN})_{2}[22,32]$ according to the previously reported method [34] for the synthesis of $\mathbf{1 8 c}$ with some modification to improve the yield.

The structures of the new dibenzoxines products 18a.b and 19 were confirmed using ${ }^{1} \mathrm{H}$ and ${ }^{13} \mathrm{CNMR}$ and microanalysis (Scheme 4).

2.1.3. Synthesis of the 2-Methylthio-substituted-1,3-oxazines. 2-Methylthio-substituted-1,3-oxazines 14a-i (a R = H, b R = $8-\mathrm{CH}_{3}, \mathbf{c} \mathrm{R}=8-\mathrm{Ph}, \mathbf{d ~ R}=7-\mathrm{OCH}_{3}$, e $\mathrm{R}=7-\mathrm{OCH}_{2} \mathrm{CH}_{3}$, f R $=7-\mathrm{OH}, \mathbf{g ~ R}=7-\mathrm{OH},-8-\mathrm{CH}_{3}, \mathbf{h ~ R}=\mathrm{AcNH}$, and $\mathrm{I} \mathrm{R}=\mathrm{NH}_{2}$ ) and 24 were prepared by the reaction of $\mathrm{CH}_{3} \mathrm{I}$ in the presence of $\mathrm{NaHCO}_{3}$ with substituted-1,3-oxazines $\mathbf{6}, \mathbf{1 0 a}, \mathbf{b}, \mathbf{1 1}$, and $12\left(\mathbf{a ~ R}=8-\mathrm{CH}_{3}, \mathbf{b} \mathrm{R}=8-\mathrm{Ph}, \mathbf{e} \mathrm{R}=7-\mathrm{OCH}_{2} \mathrm{CH}_{3}, \mathbf{h ~ R}=7-\right.$ $\mathrm{OCH}_{3}, \mathbf{k ~ R}=7-\mathrm{OH}$, and $\mathbf{l} \mathrm{R}=7-\mathrm{OH},-8-\mathrm{CH}_{3}$ ) according to the previously reported procedure [35]. Physical properties, IR, ${ }^{1} \mathrm{H} \mathrm{NMR}$, and ${ }^{13} \mathrm{C}$ NMR, collected for products $14 \mathbf{a}-\mathrm{I}$ were found to be identical to the reported data [35]. The structures of new product, $\mathbf{1 4} \mathbf{h}, \mathbf{i}$, and $\mathbf{2 4}$ were confirmed with analysis of the IR, ${ }^{1} \mathrm{H}$, and ${ }^{13} \mathrm{C}$ NMR data.

Compounds 14a-i and 24 were used in the synthesis of compounds 15a-I and 26 with no further purification.

2.1.4. Synthesis of Benzyl Thiourea 13a-q, 20a, c, and 21. Initially, the equimolar reaction of compound 6 with benzylamine in dioxane was repeated according to the earlier reported method $[19,20]$, in which the mixture that was refluxed for 4 hours gave 13a and was a $46 \%$ yield (Scheme 3 ).

However, when the reaction was carried out using solvent free conditions, excess benzylamine was added directly to powered 2-thio-1,3-benzoxazine 6 and the mixture was left at room temperature for 2 days, the benzyl thiourea product 13a 


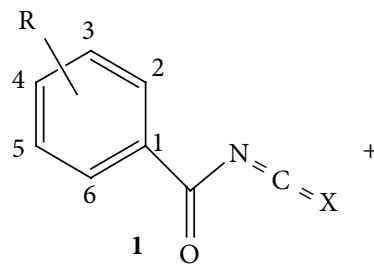<smiles>[R]c1ccc(C(=O)NC(=O)N2CCCCN2)cc1</smiles><smiles>[R]c1ccccc1C(=O)Oc1ccccc1C(=O)N[CH2+]C(=O)OCC</smiles><smiles>[R]c1ccc2c(=O)nc(N3[Y]CCC[Al]3)oc2c1</smiles>

SCHEme 1: Previous synthesis of urea or thiourea $3(\mathrm{X}=\mathrm{O}$ or $\mathrm{S}$ ) and 2-amino benzol,3-oxazine 5.<smiles>Nc1ccc(C(=O)O)c(O)c1</smiles>

7<smiles>[R]c1ccc(C(=O)O)c(O)c1</smiles>

8<smiles>[R]c1ccc2c(=O)[nH]c(=S)oc2c1</smiles>

10

$$
\text { a } \mathrm{R}=\mathrm{AcNH}
$$$$
\text { b } \mathrm{R}=\text { phenyl- } \mathrm{C}=\mathrm{N}
$$$$
\text { a } \mathrm{R}_{1}=\mathrm{AcNH}
$$$$
\text { b } \mathrm{R}_{1}=\mathrm{NH} 2
$$

d R = 3-Ethoxy-2-hydroxy-phenyl-C = N<smiles>[R3]c1c(Br)ccc(CNc2ccc(C(=O)O)c(O)c2)c1[R3]</smiles>

$$
\begin{aligned}
& \text { a } R_{1}=R_{2}=R_{3}=H \\
& \text { b } R_{2}=R_{3}=H, R_{1}=O H \\
& \text { c } R_{1}=O H, R_{2}=O E t, R_{3}=H
\end{aligned}
$$<smiles>[R3]c1c(Br)ccc(CNc2ccc3c(=O)[nH]c(=S)oc3c2)c1Br</smiles>

a $R_{1}=R_{2}=R_{3}=H$

b $\mathrm{R}_{2}=\mathrm{R}_{3}=\mathrm{H}, \mathrm{R}_{1}=\mathrm{OH}$

$c \mathrm{R}_{1}=\mathrm{OH}, \mathrm{R}_{2}=\mathrm{OEt}, \mathrm{R}_{3}=\mathrm{H}$

Scheme 2: Synthesis of 7-N-substituted-1,3-oxazines 10-11 starting from 2-hydroxy-substituted benzoic acids 8 and 9. Reaction conditions: (i) compound a $(\mathrm{Ac})_{2} \mathrm{O}$, b $\mathrm{PhCH}=\mathrm{O}$, c 2-hydroxy- $\mathrm{C}_{6} \mathrm{H}_{4}-\mathrm{CH}=\mathrm{O}$, and d 3-ethoxy-2-hydroxy- $\mathrm{C}_{6} \mathrm{H}_{3}-\mathrm{CH}=\mathrm{O},\left(\right.$ ii) $\mathrm{Ph}_{3} \mathrm{P}(\mathrm{SCN})_{2}$ in $\mathrm{CH}_{2} \mathrm{Cl}_{2}$, (iii) $\mathrm{NaBH}_{4}$, and (iv) $\mathrm{Ph}_{3} \mathrm{P}(\mathrm{SCN})_{2}$ in $\mathrm{CH}_{2} \mathrm{Cl}_{2}$. 
<smiles>[R][14c]1cccc2c(=O)[nH]c(=S)oc21</smiles>

6, 10a-b, 11c, and 12a-m

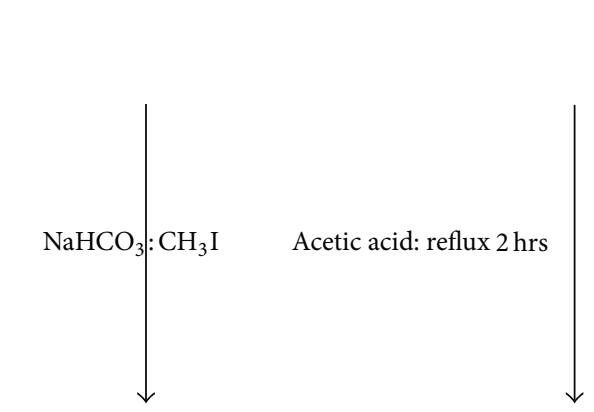<smiles>[R]c1cccc(C(=O)NC(=S)NCc2ccccc2)c1O</smiles>

13

$$
\begin{array}{lll}
\text { a: } \mathrm{R}=\mathrm{H} & (75 \%) & \text { j: } \mathrm{R}=3-\mathrm{OCH}_{3} \\
\text { b: } \mathrm{R}=3-\mathrm{CH}_{3} & (79 \%) & \text { k: } \mathrm{R}=3,5-\mathrm{I} \\
\text { c: } \mathrm{R}=3-\mathrm{Ph} & (80 \%) & \text { l: } \mathrm{R}=4-\mathrm{OH} \\
\text { d: } \mathrm{R}=5-\mathrm{Br} & (82 \%) & \text { m: } \mathrm{R}=4-\mathrm{OH}-3-\mathrm{CH}_{3} \\
\text { e: } \mathrm{R}=5-\mathrm{OCH}_{2} \mathrm{CH}_{3} & (87 \%) & \text { n: } \mathrm{R}=3-\mathrm{OH} \\
\text { f: } \mathrm{R}=4-\mathrm{OCH}_{2} \mathrm{CH}_{3} & (73 \%) & \text { o: } \mathrm{R}=\mathrm{NH}_{2} \\
\text { g: } \mathrm{R}=3-\mathrm{OCH}_{2} \mathrm{CH}_{3} & (69 \%) & \text { p: } \mathrm{R}=\mathrm{AcNH} \\
\text { h: } \mathrm{R}=5-\mathrm{OCH}_{3} & (69 \%) & \text { q: } \mathrm{R}=4\left[3-\mathrm{OEt}, 2-\mathrm{OH}\left(\mathrm{C}_{6} \mathrm{H}_{3}-\right)\right] \mathrm{NH}- \\
\text { i: } \mathrm{R}=4-\mathrm{OCH}_{3} & (69 \%) &
\end{array}
$$

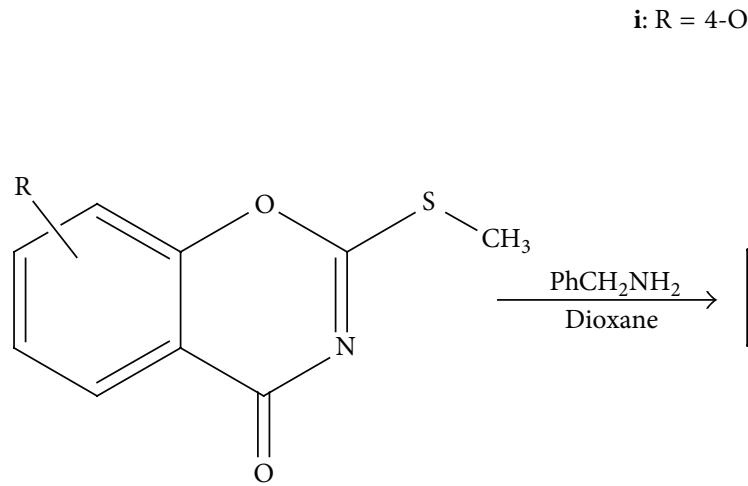

$14 a-i$
From 13 to 15

$\begin{aligned} \text { 15a: } \mathrm{R}=\mathrm{H} & (75 \%) \\ \text { 15b: } \mathrm{R}=8-\mathrm{CH}_{3} & (67 \%) \\ \text { 15e: } \mathrm{R}=7-\mathrm{OCH}_{2} \mathrm{CH}_{3} & (61 \%) \\ \text { 15f: } \mathrm{R}=7-\mathrm{OH} & (67 \%) \\ \text { 15g: } \mathrm{R}=7-\mathrm{OH}-8-\mathrm{CH}_{3} & (70 \%)\end{aligned}$

15a: $\mathrm{R}=\mathrm{H}$
15b: $\mathrm{R}=8-\mathrm{CH}_{3}$
$15 \mathrm{c}: \mathrm{R}=8-\mathrm{Ph}$
$15 \mathrm{~d}: \mathrm{R}=7-\mathrm{OH}_{3}$
$15 \mathrm{e}: \mathrm{R}=7-\mathrm{OCH}_{2} \mathrm{CH}_{3}$

(82\%)<smiles>[R]C=c1oc(NCc2ccccc2)nc(=O)c1=CCC</smiles>

15

From 14 to 15
(75\%)
15f: $\mathrm{R}=7-\mathrm{OH}$
(77\%)
15g: $\mathrm{R}=7-\mathrm{OH},-8-\mathrm{CH}_{3}$
(74\%)
$(65 \%)$
15h: $\mathrm{R}=\mathrm{AcNH}$
$(47 \%)$
$(83 \%)$
15i: $\mathrm{R}=\mathrm{NH}_{2}$
$(47 \%)$

Scheme 3: Synthesis of $N$-(benzyl carbamothioyl)-2-hydroxy-substituted benzamide 13, substituted 2-benzylamino-1,3-benzoxazines 15.

had decreased yield (19\%), and none of the cyclic analogue 15a could be isolated. When 2-thio-1,3-benzoxazine 6 was allowed to react with excess benzylamine (4-fold) and the mixture was then heated to reflux in dioxane for 2 hours, the open product 13a was again isolated in $18 \%$ yield.

To overcome this low yield and possible mixture formation, the reaction procedure was modified in which the benzoxazines $\mathbf{6}, 10 \mathbf{a}-\mathbf{b}, 11 \mathrm{~d}$, and $\mathbf{1 2 b}-\mathbf{m}$ were mixed with $\mathrm{NaHCO}_{3}$ and suspended in 1:1 mixture of methanol, water and the mixture was then heated to $40^{\circ} \mathrm{C}$ for a few minutes. Excess (1.5-fold) benzyl amine was added dropwise at room temperature and left stirring for 4 hours. Products 13aq was isolated according to the general procedure B (see Experimental) and the yield were moderate to high (69-87\%) (Scheme 3).
With slight modification to the procedure $\mathrm{B}$, by altering the ratio of benzylamine to starting material $(3: 1)$ and the reaction time to 16 hours, the bis-oxazines $18 \mathrm{a}, \mathrm{c}$ and 19 were found to react in a similar fashion to give substituted bis(benzyl carbamothioyl) analogues 20a,c (yield 63, 49\%) and 21 (yield 63\%) (Scheme 4).

The previously prepared N-(benzyl carbamothioyl)-2hydroxybenzamide 13a was characterized by comparison of its physical data (mp, IR, ${ }^{1} \mathrm{H}$ and ${ }^{13} \mathrm{C}$ NMR spectra) with values found in the literature $[12,19,20]$. The structures of new benzyl thiourea compounds $13 \mathbf{b}-\mathbf{q}, \mathbf{2 0 a}, \mathbf{c}$, and 21 were confirmed using IR, ${ }^{1} \mathrm{H}$ NMR and ${ }^{13} \mathrm{C}$ NMR spectroscopy and microanalysis. The ${ }^{1} \mathrm{H}$ NMR and IR spectra also showed a high correlation with the previously prepared benzyl thiourea 
<smiles>[R]c1c(O)c(C(=O)O)cc(C(=O)NC(=S)NCc2ccccc2)c1O</smiles><smiles>[R20][R](C)=C[Si]=C1NC(=O)c2ccc3c(=O)[nH]c(=S)oc3c2O1</smiles>

Scheme 4: Synthesis of substituted-N,N-bis(benzyl carbamothioyl)-dihydroxy-iso and tetra phthalamides 20a, c, and 21. Reaction conditions: (i) $\mathrm{Ph}_{3} \mathrm{P}(\mathrm{SCN})_{2}$ in $\mathrm{CH}_{2} \mathrm{Cl}_{2}$ and (ii) $\mathrm{NaHCO}_{3}, \mathrm{PhCH}_{2} \mathrm{NH}_{2}$.

13a $[19,20]$. In the ${ }^{1} \mathrm{H}$ NMR spectra, the $\mathrm{CH}_{2}, \mathrm{H}-5^{\prime}$ of the benzyl amine in compounds 13a-q, 20a,c, and 21 appeared as a doublet at $\sim \delta 4.9 \mathrm{ppm}$ and the $4^{\prime}-\mathrm{NH}$, appeared as a triplet at $\sim \delta 11.0 \mathrm{ppm}$ in all cases. Assignment of the carbon13 chemical shifts was made using the previous reported chemical shifts of $13 \mathbf{a}[19,20]$. The ${ }^{1} \mathrm{H}$ and ${ }^{13} \mathrm{C}$ NMR spectra of the parent 2-thioxo-2H-benz[e]-1,3-oxazin-4(3H)-one 12 were also used to aid with structural identification. The simulated ${ }^{1} \mathrm{H}$ and ${ }^{13} \mathrm{C}$ NMR spectra using ChemDraw V12 ultra were also used as references to aid the analysis of the observed ${ }^{1} \mathrm{H}$ and ${ }^{13} \mathrm{C}$ NMR spectra of the new products.

\subsubsection{Synthesis of 2-Benzyl amino-(substituted)-benz-1,3-ox-} azines 15. As mentioned earlier the reaction of the 2-thio-1,3benzoxazine 6 with a primary amine did not consistently give the cyclic product 13a $[19,20]$.

The reaction of 2-methylthio-(substituted)-1,3-benzoxazines $14\left(\mathbf{a ~ R}=\mathrm{H}, \mathbf{b} \mathrm{R}=8-\mathrm{CH}_{3}, \mathbf{c ~ R}=8-\mathrm{Ph}, \mathbf{d ~ R}=7-\mathrm{OCH}_{3}, \mathbf{e}\right.$ $\mathrm{R}=7-\mathrm{OCH}_{2} \mathrm{CH}_{3}$, f $\mathrm{R}=7-\mathrm{OH}, \mathbf{g} \mathrm{R}=7-\mathrm{OH},-8-\mathrm{CH}_{3}$, and $\mathbf{h} \mathrm{R}=$ AcNH-) and 24 with excess (5-fold) benzyl amine according to the general procedure $\mathrm{C}$ gave 2-benzyl amino-substituted1,3-benzoxazines $\mathbf{1 5} \mathbf{a}-\mathbf{h}$ and $\mathbf{2 6}$ with moderate to high yields 62-83\% (Schemes 3 and 5).

The reaction of benzylamine with 2-methylthio-benzoxazine took place with no trace of the thiourea analogue $\mathbf{1 3 .}$

Following their successful synthesis, many of the $N$-(benzyl carbamothioyl)-2-hydroxybenzamides 13a, b, f, and $\mathbf{g}$ were then cyclised by refluxing in acetic acid for 2 hours according to the general procedure $\mathrm{D}$ (Scheme 3 ) and gave the corresponding 2-benzylamino-1,3-benzoxazines $\mathbf{1 5 a}, \mathbf{b}, \mathbf{f}$, and $\mathbf{g}$ fair to good yields.

Previously prepared 2-benzyl amino-1,3-benzoxazine 15a was characterized by comparison of the physical data ( $\mathrm{mp}$, IR, and ${ }^{1} \mathrm{H}$ and ${ }^{13} \mathrm{C}$ NMR spectra) with that found in the literature $[19,20]$. The structures of new 2-benzyl amino-1,3benzoxazine compounds $\mathbf{1 5 b} \mathbf{b}$-g were confirmed using IR, ${ }^{1} \mathrm{H}$ NMR, and ${ }^{13} \mathrm{C}$ NMR spectroscopy and microanalysis. In the ${ }^{1} \mathrm{H}$ spectra the $\mathrm{CH}_{2}$ of the benzyl amine appears as a doublet at $\sim \delta 4.5 \mathrm{ppm}$. The previously analysed ${ }^{1} \mathrm{H}$ and ${ }^{13} \mathrm{C} \mathrm{NMR}$ spectra of the parent 2-methylthio-1,3-benzoxazines 14 [35] were used to aid in the analysis of the new products $15 \mathbf{b}-\mathbf{g}$ s.

2.1.6. Synthesis of 2-Oxo-substituted-benzoxazines $22 \boldsymbol{a}-\boldsymbol{h}$ and 25. 2-Methylthio-substituted-benzoxazines $14 \mathbf{a}, \mathbf{b}$, and $\mathbf{d - g}$ were allowed to react with $10 \% \mathrm{HCl}$ according to the general procedure E and gave 2-dione-1,3-benzoxazines 22a-h with good to excellent yield (Scheme 5); however, product $\mathbf{2 2} \mathbf{h}$ was produce if $40 \% \mathrm{HCl}$ was used in the hydrolysis of 14h. Similarly, the 2,8 -dioxo product 25 was prepared from the hydrochloric acid hydrolysis of the corresponding 2,8dimethylthio-analogue 24 (Scheme 5).

2.1.7. Synthesis of Substituted-N-(benzyl carbamoyl)-2-hydroxybenzamides $\mathbf{2 3 a - g}$. The synthesis of the substitutedN-(benzyl carbamoyl)-2-hydroxybenzamides 23a-g was achieved using the reaction of the relevant benzoxazine- 2 , 4-di-one $\mathbf{2 2} \mathbf{a}-\mathbf{h}$ with excess benzylamine in dioxane with refluxed according to the general procedure $\mathbf{F}$.

Structure Elucidation of Substituted-N-(benzyl carbamoyl)2-hydroxybenzamides $\mathbf{2 3 a - g}$. The structures of the newly prepared substituted urea compounds $\mathbf{2 3 a - g}$ were confirmed using IR and ${ }^{1} \mathrm{H}$ and ${ }^{13} \mathrm{C}$ NMR spectroscopy and microanalysis. The ${ }^{1} \mathrm{H}$ NMR and IR spectra supported the proposed structures and showed some correlation with the previously prepared benzyl thiourea $\mathbf{1 3 a - q}, \mathbf{2 0 a}, \mathbf{c}$, and 21 . In the ${ }^{1} \mathrm{H}$ spectra, the methylene $\mathrm{CH}_{2}$ (H-11 of compounds $23 \mathbf{a}-\mathbf{g}$ ) of the benzyl amine appears to shift up field as a doublet at $\sim \delta 4.3 \mathrm{ppm}$. The $\mathrm{NH}$ (H-10 of compounds $23 \mathbf{a}-\mathbf{g}$ ) appears as 
<smiles>[R]c1cccc(C(=O)NC(=O)NCc2ccccc2)c1O</smiles>

22

$$
\begin{array}{ll}
\text { a } \mathrm{R}=\mathrm{H} & \text { e } \mathrm{R}=7-\mathrm{OH} \\
\text { b R }=8-\mathrm{CH}_{3} & \text { f R }=7-\mathrm{OH}, 8-\mathrm{CH}_{3} \\
\text { c } \mathrm{R}=7-\mathrm{OCH}_{3} & \text { g R }=\mathrm{AcNH} \\
\text { d } \mathrm{R}=7-\mathrm{OCH}_{2} \mathrm{CH}_{3} & \text { h R }=\mathrm{NH}_{2}
\end{array}
$$$$
\text { a } \mathrm{R}=\mathrm{H}
$$$$
\text { b R }=3-\mathrm{CH}_{3}
$$$$
\text { c R }=4-\mathrm{OCH}_{2} \mathrm{CH}_{3}
$$$$
\text { d R }=4-\mathrm{OH}
$$

23

$$
\begin{aligned}
& \text { e } \mathrm{R}=4-\mathrm{OH}, 3-\mathrm{CH}_{3} \\
& \text { f R }=\mathrm{AcNH}- \\
& \text { g R }=\mathrm{NH}_{2}
\end{aligned}
$$<smiles>CSC1=NC(=O)c2cc3c(=O)nc(SCC(C)CN)oc3c(C)c2OC(CC(C)C)=N1</smiles>

Scheme 5: Synthesis of 2-dione-1,3-benzoxazines 22a-I and 25a,b from the 2-methylthio-1,3-benzoxazines 14a,b, d-g, and 24a-b.

a broad triplet at $\sim \delta 8.5 \mathrm{ppm}$. The ${ }^{1} \mathrm{H}$ and ${ }^{13} \mathrm{C}$ NMR spectra of the parent 2-oxo-1,3-benzoxazines 22 and $\mathbf{2 5}$.

\subsection{Biological Testing}

2.2.1. Broth Dilution Susceptibility Testing. In this study, some of the newly prepared compounds were tested and showed antimicrobial activity against 8 different bacterial strains and 4 cultures of fungi. The bacterial species investigated were $P$. aeruginosa, B. subtilis, S. aureus, A. baumannii, E. coli, S. agalactiae M. smegmatis, and M. chlorophenolicum. The antifungal evaluation was determined against $A$. niger, $A$. corymbifera, $R$. oryzae, and A. alternata. The minimal inhibitory concentrations (MICs) and minimal fungicidal concentrations (MFCs), defined as the lowest concentration of drug that inhibits the growth of bacteria or fungi in the inoculums', were determined using the broth dilution methods. The compounds which demonstrated MIC and MFC values less than 300 and $200 \mu \mathrm{g} \mathrm{mL}^{-1}$, respectively, are listed in Tables 1 and 2. According to [36], antimicrobial agents are effective on a range of bacterial species at low concentrations, that is, $<128 \mu \mathrm{g} \mathrm{mL}^{-1}$. Therefore, we conducted our MIC experiments using concentrations as high as $300 \mu \mathrm{g} \mathrm{mL}^{-1}$. We also selected a range of bacterial and fungal species to test our newly synthesised compounds. Some of the species are potentially pathogenic to humans and animals and others are problematic in an environmental setting. Furthermore, the bacterial species selected have different cell wall compositions, that is, some are Gram-negative and some are Grampositive strains. Some antimicrobial agents inhibit bacteria by interacting with components of the cell wall that are absent in Gram-negative bacteria [37]; therefore, the selection of strains was carefully selected with the possibility that an inhibitory compound would also hint to its mechanism of action. Based on the results obtained it is clear that the Gram-negative strains, that is, $P$. aeruginosa, E. coli, and A. baumannii were least affected by the compounds and when inhibition was observed it was at high levels $200 \mu \mathrm{g} \mathrm{mL}^{-1}$ or higher. Interestingly, compound 9d seemed to have a more dramatic effect Gram-positive strains with the exception of M. smegmatis. Despite the effects that some of the compounds had on the bacterial strains, it appears that these compounds are not so effective when tested on the four fungal cultures chosen with the exception of $\mathbf{9 d}$ on A. corymbifera.

Based on the results obtained for each of the newly synthesised compounds, it is evident that compound $\mathbf{9 d}$ has more potent effect when compared to the others. This reveals that despite the fact that most of the compounds do not seem to have a noteworthy effect on the strains, compound $\mathbf{9 d}$ is of interest and further investigation is required. 
TABLE 1: Broth dilution susceptibility MIC values for inhibition growth of bacteria $\left(\mu \mathrm{gmL}^{-1}\right)$.

\begin{tabular}{|c|c|c|c|c|c|c|c|c|}
\hline \multicolumn{9}{|c|}{ Bacteria } \\
\hline \# & P. aeruginosa & B. subtilis & S. aureus & A. baumannii & E. coli & S. agalactiae & M. smegmatis & M. chloro \\
\hline $9 \mathrm{c}$ & 200 & 200 & $>200$ & 200 & 200 & $\mathrm{n} / \mathrm{a}$ & $>200$ & 50 \\
\hline $9 d$ & 200 & 100 & 25 & 200 & 200 & $\mathrm{n} / \mathrm{a}$ & $>200$ & 25 \\
\hline $13 c$ & $>300$ & $>300$ & $>300$ & $>300$ & $>300$ & $>300$ & $\mathrm{n} / \mathrm{a}$ & $\mathrm{n} / \mathrm{a}$ \\
\hline $13 d$ & 200 & $>300$ & $>300$ & 200 & $>300$ & 300 & $\mathrm{n} / \mathrm{a}$ & $\mathrm{n} / \mathrm{a}$ \\
\hline $13 e$ & $>300$ & $>300$ & 300 & $>300$ & $>300$ & $>300$ & $\mathrm{n} / \mathrm{a}$ & $\mathrm{n} / \mathrm{a}$ \\
\hline $13 \mathrm{~g}$ & $>300$ & $>300$ & $>300$ & $>300$ & $>300$ & $>300$ & $\mathrm{n} / \mathrm{a}$ & $\mathrm{n} / \mathrm{a}$ \\
\hline $13 j$ & $>300$ & $>300$ & $>300$ & $>300$ & $>300$ & 200 & $\mathrm{n} / \mathrm{a}$ & $\mathrm{n} / \mathrm{a}$ \\
\hline 131 & $>300$ & $>300$ & 300 & $>300$ & $>300$ & $>300$ & $\mathrm{n} / \mathrm{a}$ & $\mathrm{n} / \mathrm{a}$ \\
\hline $13 \mathrm{~m}$ & 200 & 200 & 300 & $>300$ & $>300$ & $>300$ & $\mathrm{n} / \mathrm{a}$ & $\mathrm{n} / \mathrm{a}$ \\
\hline $13 n$ & 300 & $>300$ & 300 & 300 & $>300$ & 300 & $\mathrm{n} / \mathrm{a}$ & $\mathrm{n} / \mathrm{a}$ \\
\hline $20 a$ & $>200$ & 12.5 & $>200$ & $>200$ & $>200$ & $\mathrm{n} / \mathrm{a}$ & $>200$ & $>200$ \\
\hline $20 \mathrm{c}$ & $>200$ & 25 & $>200$ & $>200$ & $>200$ & $\mathrm{n} / \mathrm{a}$ & $>200$ & $>200$ \\
\hline 21 & $>200$ & 25 & 200 & $>200$ & $>200$ & $\mathrm{n} / \mathrm{a}$ & 100 & 50 \\
\hline $22 \mathrm{~g}$ & 200 & $>200$ & $>200$ & 200 & $>200$ & $\mathrm{n} / \mathrm{a}$ & $>200$ & 200 \\
\hline
\end{tabular}

TABLE 2: Broth dilution susceptibility MFC values for inhibition growth of fungi $\left(\mu \mathrm{gmL}^{-1}\right)$.

\begin{tabular}{lcccc}
\hline \multicolumn{5}{c}{ Fungi } \\
$\#$ & R. oryzae & A. niger & A. corymbifera & A. alternata \\
\hline 9c & 200 & $>200$ & $>200$ & $>200$ \\
9d & 200 & $>200$ & 100 & $>200$ \\
$\mathbf{2 2 g}$ & $>200$ & $>200$ & $>200$ & $>200$ \\
$\mathbf{2 0 a}$ & $>200$ & $>200$ & $>200$ & $>200$ \\
$\mathbf{2 0 c}$ & $>200$ & $>200$ & $>200$ & $>200$ \\
$\mathbf{2 1}$ & $>200$ & $>200$ & 200 & 200 \\
\hline
\end{tabular}

2.2.2. Disc Diffusion Susceptibility Testing. Disc diffusion susceptibility testing was performed on compounds with poor solubility in broth dilution susceptibility testing. The preliminary antimicrobial testing was achieved using the standard agar disk diffusion methods. Compounds that inhibited certain bacteria or fungi are summarized in (Tables 3 and 4$)$.

The concentrations of the prepared compounds were $10^{-4} \mu \mathrm{g} \mathrm{mL}^{-1}$ (see Experimental). The control data is used to determine if the bacterial strains are resistant $(R)$ or sensitive (S) to the prepared compounds tested. The disc diffusion assay was used as a preliminary guide for all compounds and used in correspondence with the broth dilution method for determining MIC/MFC values. This method is particularly useful when MIC/MFC values are unable to be determined using the broth dilution method due to the compounds insolubility. The insoluble compounds zones of inhibition therefore can be determined in millimeters relative to the control and used as a rough guide. Since the zone of inhibition of clearance may be affected by other parameters, such as, the nutrient agar depth of the plate and solvent used, the results shown using this method therefore should be used as a guide. MIC/MFC values are determined using the broth dilution method. All compounds that showed clearance zones are listed in Tables 3 and 4 and were tested in duplicate with the average given. Any zone of inhibition that was noted around the disc was considered sensitive and the zone of clearly was noted. These results are more useful for compounds that were difficult to dissolve, but equally, these results can indicate resistance if the compound does not diffuse through the agar properly.

Based on the results obtained in Section 2.2.1, it is clear that compound $9 \mathbf{d}$ is of interest. Based on the results obtained in Table 3, compound 9d has an inhibitor effect on $M$. smegmatis but in the MIC study had no effect. This could indicate solubility problems with the compound when in solution; however, this is only speculative; further studies are required to reveal the cause. In addition, compound 9d seems to have no inhibitory effect on $S$. aureus but in the MIC studies had a dramatic affect. This difference in result is unusual but clearly indicates that different methods could reveal different results and therefore it is important to perform both methods prior to further investigation on their inhibitory effects.

In the MIC studies, we used $300 \mu \mathrm{g} \mathrm{mL}^{-1}$ as the highest cut-off level. If a compound has an inhibitory effect on any strain that is greater than this level, then this should be revealed in the disc diffusion assay. However, further investigation is required as some of these compounds are dissolved in DMSO and when applied to bacterial cultures can come out of solution. The disc diffusion assays seem to indicate some sensitivity to fungal cultures despite the fact that they were undetectable in the MIC studies.

2.3. The Structure Activity Relationships of the Tested Compounds (Broth Dilution). The results in Tables 1 and 2 show that the 4-(benzylamino)-2-hydroxybenzoic acid derivative 9d showed the broadest range of activity of the compounds tested, exhibiting activity against the Gram-positive and Gram-negative bacteria and also M. chlorophenolicum. Furthermore, compound 9d showed to be more active than 
TABLE 3: Results showing Disc diffusion susceptibility for the synthesised compounds.

\begin{tabular}{|c|c|c|c|c|c|c|c|c|}
\hline \multicolumn{9}{|c|}{ Bacteria } \\
\hline \# & P. aeruginosa & B. subtilis & S. aureus & A. baumannii & E. coli & S. agalactiae & M. smegmatis & M. chloro \\
\hline $8 \mathrm{c}$ & $\mathrm{S}(2 \mathrm{~mm})$ & $\mathrm{R}$ & $\mathrm{R}$ & $\mathrm{R}$ & $\mathrm{R}$ & $\mathrm{n} / \mathrm{a}$ & $\mathrm{S}(2 \mathrm{~mm})$ & $\mathrm{R}$ \\
\hline $8 d$ & $\mathrm{~S}(2 \mathrm{~mm})$ & $\mathrm{S}(3 \mathrm{~mm})$ & $\mathrm{R}$ & $\mathrm{R}$ & $\mathrm{R}$ & $\mathrm{n} / \mathrm{a}$ & $\mathrm{S}(2 \mathrm{~mm})$ & $\mathrm{S}(2 \mathrm{~mm})$ \\
\hline $9 c$ & $\mathrm{~S}(2 \mathrm{~mm})$ & $\mathrm{S}(2 \mathrm{~mm})$ & $\mathrm{R}$ & $\mathrm{R}$ & $\mathrm{R}$ & $\mathrm{n} / \mathrm{a}$ & $\mathrm{S}(2 \mathrm{~mm})$ & $\mathrm{S}(2 \mathrm{~mm})$ \\
\hline 9d & $\mathrm{S}(2 \mathrm{~mm})$ & $\mathrm{S}(4 \mathrm{~mm})$ & $\mathrm{R}$ & $\mathrm{R}$ & $\mathrm{R}$ & $\mathrm{n} / \mathrm{a}$ & $\mathrm{S}(2 \mathrm{~mm})$ & $\mathrm{S}(2 \mathrm{~mm})$ \\
\hline $13 b$ & $\mathrm{R}$ & $\mathrm{S}(6 \mathrm{~mm})$ & $\mathrm{S}(5 \mathrm{~mm})$ & $\mathrm{R}$ & $\mathrm{R}$ & $\mathrm{S}(5 \mathrm{~mm})$ & $\mathrm{n} / \mathrm{a}$ & $\mathrm{n} / \mathrm{a}$ \\
\hline $13 k$ & $\mathrm{R}$ & $\mathrm{S}(2 \mathrm{~mm})$ & $\mathrm{S}(5 \mathrm{~mm})$ & $\mathrm{S}(2 \mathrm{~mm})$ & $\mathrm{R}$ & $\mathrm{S}(5 \mathrm{~mm})$ & $\mathrm{n} / \mathrm{a}$ & $\mathrm{n} / \mathrm{a}$ \\
\hline $13 \mathrm{f}$ & $\mathrm{R}$ & $\mathrm{S}(2 \mathrm{~mm})$ & $\mathrm{S}(5 \mathrm{~mm})$ & $\mathrm{S}(2 \mathrm{~mm})$ & $\mathrm{R}$ & $\mathrm{S}(5 \mathrm{~mm})$ & $\mathrm{n} / \mathrm{a}$ & $\mathrm{n} / \mathrm{a}$ \\
\hline $15 d$ & $\mathrm{R}$ & $\mathrm{S}(2 \mathrm{~mm})$ & $\mathrm{S}(5 \mathrm{~mm})$ & $\mathrm{S}(2 \mathrm{~mm})$ & $\mathrm{R}$ & $\mathrm{S}(5 \mathrm{~mm})$ & $\mathrm{n} / \mathrm{a}$ & $\mathrm{n} / \mathrm{a}$ \\
\hline $15 \mathrm{e}$ & $\mathrm{R}$ & $\mathrm{R}$ & $\mathrm{R}$ & $\mathrm{R}$ & $\mathrm{R}$ & $\mathrm{R}$ & $\mathrm{n} / \mathrm{a}$ & $\mathrm{n} / \mathrm{a}$ \\
\hline 130 & $\mathrm{R}$ & $\mathrm{R}$ & $\mathrm{R}$ & $\mathrm{R}$ & $\mathrm{R}$ & - & $\mathrm{R}$ & $\mathrm{R}$ \\
\hline $13 p$ & $\mathrm{R}$ & $\mathrm{R}$ & $\mathrm{R}$ & $\mathrm{R}$ & $\mathrm{R}$ & $\mathrm{n} / \mathrm{a}$ & $\mathrm{S}(2 \mathrm{~mm})$ & $\mathrm{R}$ \\
\hline $13 q$ & $\mathrm{R}$ & $\mathrm{R}$ & $\mathrm{R}$ & $\mathrm{R}$ & $\mathrm{R}$ & $\mathrm{n} / \mathrm{a}$ & $\mathrm{R}$ & $\mathrm{R}$ \\
\hline $20 a$ & $\mathrm{R}$ & $\mathrm{S}(2 \mathrm{~mm})$ & $\mathrm{R}$ & $\mathrm{R}$ & $\mathrm{R}$ & $\mathrm{n} / \mathrm{a}$ & $\mathrm{R}$ & $\mathrm{R}$ \\
\hline $20 c$ & $\mathrm{R}$ & $\mathrm{S}(2 \mathrm{~mm})$ & $\mathrm{R}$ & $\mathrm{R}$ & $\mathrm{R}$ & $\mathrm{n} / \mathrm{a}$ & $\mathrm{S}(3 \mathrm{~mm})$ & $\mathrm{S}(4 \mathrm{~mm})$ \\
\hline 21 & $\mathrm{R}$ & $\mathrm{S}(4 \mathrm{~mm})$ & $\mathrm{R}$ & $\mathrm{R}$ & $\mathrm{R}$ & $\mathrm{n} / \mathrm{a}$ & $\mathrm{R}$ & $\mathrm{R}$ \\
\hline $22 \mathrm{~h}$ & $\mathrm{R}$ & $\mathrm{R}$ & $\mathrm{R}$ & $\mathrm{R}$ & $\mathrm{R}$ & $\mathrm{n} / \mathrm{a}$ & $\mathrm{S}(3 \mathrm{~mm})$ & $\mathrm{S}(3 \mathrm{~mm})$ \\
\hline $22 \mathrm{i}$ & $\mathrm{R}$ & $\mathrm{R}$ & $\mathrm{R}$ & $\mathrm{R}$ & $\mathrm{R}$ & $\mathrm{n} / \mathrm{a}$ & $\mathrm{S}(2 \mathrm{~mm})$ & $\mathrm{R}$ \\
\hline $23 \mathrm{~g}$ & $\mathrm{R}$ & $\mathrm{R}$ & $\mathrm{R}$ & $\mathrm{R}$ & $\mathrm{R}$ & $\mathrm{n} / \mathrm{a}$ & $\mathrm{R}$ & $\mathrm{R}$ \\
\hline
\end{tabular}

TABle 4: Disc diffusion susceptibility for the synthesised compounds.

\begin{tabular}{lcccc}
\hline \multicolumn{5}{c}{ Fungi } \\
$\#$ & R. oryzae & A. niger & A. corymbifera & A. alternata \\
\hline $\mathbf{8 c}$ & $\mathrm{R}$ & $\mathrm{R}$ & $\mathrm{R}$ & $\mathrm{R}$ \\
$\mathbf{8 d}$ & $\mathrm{S}(2 \mathrm{~mm})$ & $\mathrm{S}(3 \mathrm{~mm})$ & $\mathrm{S}(5 \mathrm{~mm})$ & $\mathrm{R}$ \\
$\mathbf{9 c}$ & $\mathrm{R}$ & $\mathrm{R}$ & $\mathrm{R}$ & $\mathrm{R}$ \\
$\mathbf{9 d}$ & $\mathrm{R}$ & $\mathrm{R}$ & $\mathrm{R}$ & $\mathrm{R}$ \\
$\mathbf{1 3} \mathbf{p}$ & $\mathrm{S}(2 \mathrm{~mm})$ & $\mathrm{R}$ & $\mathrm{R}$ & $\mathrm{R}$ \\
$\mathbf{1 3 q}$ & $\mathrm{S}(2 \mathrm{~mm})$ & $\mathrm{S}(2 \mathrm{~mm})$ & $\mathrm{S}(3 \mathrm{~mm})$ & $\mathrm{R}$ \\
$\mathbf{2 1 c}$ & $\mathrm{S}(2 \mathrm{~mm})$ & $\mathrm{S}(2 \mathrm{~mm})$ & $\mathrm{S}(3 \mathrm{~mm})$ & $\mathrm{R}$ \\
$\mathbf{2 0 a}$ & $\mathrm{R}$ & $\mathrm{R}$ & $\mathrm{R}$ & $\mathrm{R}$ \\
$\mathbf{2 0 c}$ & $\mathrm{R}$ & $\mathrm{R}$ & $\mathrm{R}$ & $\mathrm{R}$ \\
$\mathbf{2 2 h}$ & $\mathrm{R}$ & $\mathrm{R}$ & $\mathrm{R}$ & $\mathrm{R}$ \\
$\mathbf{2 2 i}$ & $\mathrm{R}$ & $\mathrm{R}$ & $\mathrm{R}$ & $\mathrm{R}$ \\
$\mathbf{2 5 b}$ & $\mathrm{R}$ & $\mathrm{R}$ & $\mathrm{R}$ & $\mathrm{R}$ \\
\hline
\end{tabular}

others against $S$. aureus with an MIC value of $25 \mu \mathrm{g} / \mathrm{mL}$. Compounds 20a,c and 21 (bis-thiourea products) were found to be particularly active towards Gram-positive B. subtilis at MIC values of $12.5,25$, and $25 \mu \mathrm{g} \mathrm{mL}^{-1}$. In addition, compound 21 also showed activity towards $M$. smegmatis (MIC $50 \mu \mathrm{g} \mathrm{mL}^{-1}$ ). Other synthesized compounds which showed an inhibitory effect were $\mathbf{1 3} \mathbf{n}$ which had an inhibitory effect on four bacterial species at $300 \mu \mathrm{g} \mathrm{mL}^{-1}$ and $\mathbf{1 3 d}$ and $\mathbf{1 3} \mathbf{m}$ which had an inhibitory effect on two of the bacterial species at concentration $200 \mu \mathrm{g} \mathrm{mL}^{-1}$. Interestingly, E. coli was not inhibited by any of the compounds.

2.4. The Chemical Compounds Activity and Structural Relationships of the Antimicrobial Assay Results (From Disk Diffusion Assay). In the presence of a compound, a zone of clearing was greater than the control which was indicative that the strain was sensitive to the compound, whereas a zone of clearing equal to the control indicated resistance. The results reveal that none of the compounds had an inhibitory effect on E. coli at concentration $10^{4} \mu \mathrm{g} \mathrm{mL}^{-1}$ (Table 3). The B. subtilis bacterial species tested showed inhibitory effects to most of the compounds tested, for example, 13d inhibited $S$. aureus most strongly and compounds $13 \mathbf{k}, \mathbf{1 3 f}$, and $\mathbf{1 3 d}$ inhibited growth of A. baumannii, B. subtilis, and S. agalactiae (Table 3). Some bacterial species that were sensitive to a compound showed similar sized zones of inhibition. One example was 13k which exhibited activity of $2 \mathrm{~mm}$ for $A$. baumannii and B. subtilis and $5 \mathrm{~mm}$ for $S$. aureus and $S$. agalactiae. The same applies to compounds $\mathbf{8 d}, \mathbf{9 c}$, and $\mathbf{9 d}$ which had shown a $2 \mathrm{~mm}$ clearance zone against $P$. aeruginosa M. smegmatis $M$. chlorophenolicum. Similarly to the broth dilution results, compounds $\mathbf{2 1}$ and $\mathbf{9 d}$ were found to be active against three fungi species, $R$. oryzae, $A$. niger, and $A$. corymbifera, with clearance zones $2-5 \mathrm{~mm}$, respectively.

All the compounds tested showed a $2-4 \mathrm{~mm}$ zone of clearing for most of the susceptible species with the exception of compound 13b which had a larger $6 \mathrm{~mm}$ zone of inhibition. This larger zone indicates a hypersensitive effect on the bacterial species; however, it is specific for the compound and species. Because the mechanism of action of the compound is unknown, it is difficult to explain the reason for the hypersensitive effect. One possible explanation is that $B$. subtilis encodes a protein that can transport compound $\mathbf{1 3 b}$ into the cell and this has a more toxic effect than those working from outside the cell. A similar phenomenon has been shown with bacterial mercury resistance where the presence of a mercury import protein displays a larger zone of clearing in a disc diffusion assay [38]. 
The data obtained revealed patterns of inhibition, especially those conducted with the disc diffusion assay. This suggests that a similar mechanism of action could be involved in the inhibition of growth.

\section{Conclusion}

In conclusion, we have prepared seven new compounds of 2-benzylamino-substituted-1,3-benzoxazines, nineteen new $\mathrm{N}$-(benzyl carbamothioyl)-substituted-benzamide and have evaluated some for their activity against bacteria and fungi. It appears that $\mathrm{N}$-(benzyl carbamothioyl)-substitutedbenzamide has shown antibacterial activity such as 20a, 20c, 21, 13d, 13m, and 13n.

We are in the process of synthesising new substituted products by replacing the benzyl group of $\mathrm{N}$-(benzyl carbamothioyl) by 6 -aminopenicillanic acid and test their bacteria activity.

\section{Experimental}

4.1. Chemistry. Infrared spectra were obtained using a Perkin Elmer FT-IR 1720x spectrometer. ${ }^{1} \mathrm{H}$ NMR and ${ }^{13} \mathrm{C} N M R$ spectra were obtained using a Bruker AC 200 NMR spectrometer at 200 and $50 \mathrm{MHz}$, respectively. All ${ }^{1} \mathrm{H}$ NMR and ${ }^{13} \mathrm{C}$ NMR spectral results are recorded as chemical shifts $(\delta)$ relative to the internal TMS for proton and $77.0 \mathrm{ppm}$ in $\mathrm{CDCl}_{3}$ solvent and $39.4 \mathrm{ppm}$ in $\mathrm{DMSO}-\mathrm{d}_{6}$ solvent for ${ }^{13} \mathrm{C}$ NMR. Microanalysis was performed by Chemical and Micro analytical Services (CMAS), Australia. Melting point determinations were carried out using a Stuart Scientific (SMP3) melting point apparatus and all melting points are uncorrected.

4.1.1. Starting Materials. The stating reagents benzyl amine, sodium hydrogen carbonate, methyl iodide-amino-2-hydroxybenzoic acid, and dry 1,4-dioxane were purchased from Aldrich Chemical Company and were used as received.

4.1.2. Synthesis of 4-(Acetyl amino)-2-hydroxybenzoic Acid $8 a$. According to the previously reported method $[29,30$, 37], product 8a was prepared from the reaction of 4amino-2-hydroxybenzoic acid 7 and acetic anhydride and recrystallised from 1,4 -dioxane, $82 \%$ yield, mp $221-224^{\circ} \mathrm{C}$ (lit [37] and $\mathrm{mp} 235^{\circ} \mathrm{C}$ ). The physical and spectroscopic data is consistent with the literature values $[27,35]$.

4.1.3. Synthesis of 4-Substituted ((Benzylidene)amino)-2-hydroxybenzoic Acid Intermediates $8 \boldsymbol{b}-\boldsymbol{e}$. According to the previously reported method $[29,30]$, intermediates $\mathbf{8 b}$-e were prepared from the appropriate substituted benzaldehyde and 4-amino-2-hydroxy-benzoic acid 7.

Products $\mathbf{8 b}$, c, and e were not identified and used immediately in the synthesis of compound $\mathbf{9 a}, \mathbf{b}$, and $\mathbf{d}$.

(Z)-4-((3-Ethoxy-2-hydroxybenzylidene)amino)-2-hydroxybenzoic Acid 8d. 3-Ethoxy-2-hydroxybenzaldehyde (1.66 g,
$0.01 \mathrm{~mol}$ ) was allowed to react with 4-amino-2-hydroxybenzoic acid $7(1.53 \mathrm{~g}, 0.01 \mathrm{~mol})$ for 1 hour according to the reported procedure $[29,30]$ and gave solid which recrystallised from methanol to give $8 \mathbf{d} 2.95 \mathrm{~g}, 98 \%$ as red crystals, $\mathrm{mp} 185-188^{\circ} \mathrm{C}$ decomp. $\nu_{\max }(\mathrm{KBr}) / \mathrm{cm}^{-1} 1655$ $(\mathrm{C}=\mathrm{O}), 1622,1600(\mathrm{C}=\mathrm{N}):{ }^{1} \mathrm{HNMR}\left(200 \mathrm{MHz}, 300 \mathrm{~K}, \mathrm{~d}_{6^{-}}\right.$ acetone) $\delta 8.93(\mathrm{~s}, 1 \mathrm{H}, \mathrm{H}-8), 8.02\left(\mathrm{~d}, 1 \mathrm{H}, J_{\mathrm{H} 6, \mathrm{H} 5}=8.8 \mathrm{~Hz}, \mathrm{H}-6\right)$, $7.33\left(\mathrm{dd}, 1 \mathrm{H}, J_{\mathrm{H} 15, \mathrm{H} 14}=7.8 \mathrm{~Hz}, J_{\mathrm{H} 15, \mathrm{H} 13}=1.6 \mathrm{~Hz}, \mathrm{H}-15\right), 7.24$ $\left(\mathrm{dd}, 1 \mathrm{H}, J_{\mathrm{H} 13, \mathrm{H} 14}=8.0 \mathrm{~Hz}, J_{\mathrm{H} 13, \mathrm{H} 15}=1.6 \mathrm{~Hz}, \mathrm{H}-13\right), 6.91-7.09$ $(\mathrm{m}, 3 \mathrm{H}, \mathrm{H}-3, \mathrm{H}-5$, and $\mathrm{H}-14), 4.24\left(\mathrm{q}, 2 \mathrm{H}, \mathrm{J}_{\mathrm{H} 16, \mathrm{H} 17}=7.0 \mathrm{~Hz}\right.$, $\mathrm{H}-16), 1.41$ (t, 3H, $\left.\mathrm{J}_{\mathrm{H} 17, \mathrm{H} 16}=7.0 \mathrm{~Hz}, \mathrm{H}-17\right)$. Product 8d was used immediately in the synthesis of $\mathbf{9 d}$.

\subsubsection{Synthesis of 4-Substituted-(benzylamino)-2-hydroxyben- zoic Acids $9 a-d$}

General Procedure A. In slight modification to a previous reported method, [28] the appropriate 4-substituted ((benzylidene) amino)-hydroxybenzoic acids $\mathbf{8 b}$-c reduced using sodium borohydride (2 equiv).

4-(Benzylamino)-2-hydroxybenzoic Acid 9a. 2-Hydroxy-4$\{[(E)$-benzylidene $]$ amino $\}$ benzoic acid $\mathbf{8 b}(2.41 \mathrm{~g}, 10 \mathrm{mmol})$ was allowed to react with sodium borohydride $(0.76 \mathrm{~g}$, $20 \mathrm{mmol}$ ) according to general procedure A. The resulting solid was recrystallised from methanol/water to give 9a (1.76 g, 73\%), mp $122-125^{\circ} \mathrm{C} . v_{\max }(\mathrm{KBr}) / \mathrm{cm}^{-1} 3500-3200 \mathrm{br}$ $(\mathrm{OH}), 3024,2569(\mathrm{NH}), 1632(\mathrm{C}=\mathrm{O}) ;{ }^{1} \mathrm{HNMR}(200 \mathrm{MHz}$, $340 \mathrm{~K} \mathrm{~d}_{6}$-DMSO) $\delta 11.34$ (bs, $1 \mathrm{H}$, OH of COOH exchangeable with $\mathrm{D}_{2} \mathrm{O}$ ), $7.5\left(\mathrm{~d}, 1 \mathrm{H}, \mathrm{J}_{\mathrm{H} 6, \mathrm{H} 5}=8.6 \mathrm{~Hz}, \mathrm{H}-6\right), 7.21-7.47(\mathrm{~m}, 6 \mathrm{H}$, $5 \times \mathrm{CH}, 8-\mathrm{NH}$ exchangeable with $\left.\mathrm{D}_{2} \mathrm{O}\right), 6.22\left(\mathrm{dd}, 1 \mathrm{H}, J_{\mathrm{H} 5, \mathrm{H} 6}=\right.$ $\left.8.6 \mathrm{~Hz}, J_{\mathrm{H} 5, \mathrm{H} 8}=2.0 \mathrm{~Hz}, \mathrm{H}-5\right), 6.03\left(\mathrm{~d}, 1 \mathrm{H}, J_{\mathrm{H} 3, \mathrm{H} 5}=2.0 \mathrm{~Hz}, \mathrm{H}-\right.$ 3), 4.38 (s, $2 \mathrm{H}, \mathrm{H}-9) .3 .32$ (2-OH under the water envelope); ${ }^{13} \mathrm{C} \mathrm{NMR}\left(50 \mathrm{MHz}, 340 \mathrm{~K}, \mathrm{~d}_{6}\right.$-DMSO) $\delta 171.7$ (C-7), 163.2 (C2), 154.8 (C-4), 139.1 (C-10), 130.1 (C-6), 128.1, 126.9, 126.6 (C12, C-11 and C-13), 105.3 (C-5), 100.4 (C-1), 96.8 (C-3), 45.8 (C-9). The resulting product 9 a was not stable and was used immediately in the genral procedure $B$.

2-Hydroxy-4-((2-hydroxybenzyl)amino)benzoic Acid 9b. (E)2-Hydroxy-4-((2-hydroxybenzylidene)amino)benzoic acid $8 \mathrm{c}(2.6 \mathrm{~g}, 10 \mathrm{mmol})$ was allowed to react with sodium borohydride $(0.76 \mathrm{~g}, 20 \mathrm{mmol})$ according to general procedure A. The resulting solid was recrystallised from methanol/water to give $\mathbf{9 b}$ as white crystals $(2.20 \mathrm{~g}, 85 \%), \mathrm{mp} 184-186^{\circ} \mathrm{C}$ decomp. $v_{\max }(\mathrm{KBr}) / \mathrm{cm}^{-1} 3500-3200$ br $(\mathrm{OH}), 1614(\mathrm{C}=\mathrm{O})$; ${ }^{1} \mathrm{HNMR}\left(200 \mathrm{MHz}, 300 \mathrm{~K} \mathrm{~d}_{6}\right.$-DMSO) $\delta 11.45$ (bs, 1H, 8-NH or 11-OH exchangeable with $\mathrm{D}_{2} \mathrm{O}$ ), 9.61 (bs, $1 \mathrm{H}, 11-\mathrm{OH}$ or 8-NH exchangeable with $\left.\mathrm{D}_{2} \mathrm{O}\right) 7.44\left(\mathrm{~d}, 1 \mathrm{H}, J_{\mathrm{H} 6, \mathrm{H} 5}=8.8 \mathrm{~Hz}\right.$, H-6), 7.1-6.7 (m, 6H, H-13, H-15, H-14, H-12 and 11-OH), 6.28 $\left(\mathrm{dd}, 1 \mathrm{H}, J_{\mathrm{H} 5, \mathrm{H} 6}=8.8 \mathrm{~Hz}, J_{\mathrm{H} 5, \mathrm{H} 3}=1.1 \mathrm{~Hz}, \mathrm{H}-5\right), 5.92(\mathrm{~d}, 1 \mathrm{H}$, $\left.J_{\mathrm{H} 3, \mathrm{H} 5}=1.1 \mathrm{~Hz}, \mathrm{H}-3\right) ;{ }^{13} \mathrm{C} \mathrm{NMR}\left(50 \mathrm{MHz}, 350 \mathrm{~K}, \mathrm{~d}_{6}\right.$-DMSO $)$ $\delta 171.9$ (C-7), 163.5 (C-2), 155.2/155.0 (C-11/C-4), 131.2 (C-6), 128.5 (C-13), 127.9 (C-14), 125.0 (C-10), 119.1 (C-15), 115.3 (C-12), 105.6 (C-5), 100.6 (C-1), 97.0 (C-3), 41.1 (C-8). The resulting product $9 \mathrm{~b}$ was used immediately in the general procedure B. 
4-((3-Ethoxy-2-hydroxybenzyl)amino)-2-hydroxybenzoic Acid 9c. (E)-4-((3-Ethoxy-2-hydroxybenzylidene)amino)-2hydroxybenzoic acid $\mathbf{8 d}(10 \mathrm{mmol}, 3.0 \mathrm{~g})$ was allowed to react with sodium borohydride $(20 \mathrm{mmol}, 0.76 \mathrm{~g})$ according to general procedure $\mathrm{A}$. The resulting solid was collected and recrystallised from methanol/water to give 9d (2.66 g, 81\%) as white crystals, mp $159-161^{\circ} \mathrm{C}$ decomp. $\nu_{\max }(\mathrm{KBr}) / \mathrm{cm}^{-1}$ 3500-3200 br (OH, NH absorption under the $\mathrm{OH}$ envelope), $1625(\mathrm{C}=\mathrm{O}) ;{ }^{1} \mathrm{HNMR}\left(200 \mathrm{MHz}, 300 \mathrm{~K} \mathrm{~d}_{6}\right.$-DMSO) $\delta 7.38$ (d, $\left.1 \mathrm{H}, J_{\mathrm{H} 6, \mathrm{H} 5}=8.6 \mathrm{~Hz}, \mathrm{H}-6\right), 6.85-6.65(\mathrm{~m}, 3 \mathrm{H}, \mathrm{H}-13, \mathrm{H}-14$ and $\mathrm{H}-15), 6.35$ (bs, 4H, $3 \times \mathrm{OH}$ and $\mathrm{NH}$ ), 6.17 (dd, $1 \mathrm{H}, J_{\mathrm{H} 5, \mathrm{H} 6}$ $\left.=8.6 \mathrm{~Hz}, J_{\mathrm{H} 5, \mathrm{H} 3}=1.8 \mathrm{~Hz}, \mathrm{H}-5\right), 5.87\left(\mathrm{~d}, 1 \mathrm{H}, J_{\mathrm{H} 3, \mathrm{H} 5}=1.8 \mathrm{~Hz}\right.$, $\mathrm{H}-3), 4.23$ (s, 2H, $\left.\mathrm{CH}_{2} \mathrm{NH}, \mathrm{H}-9\right), 4.05$ (q, 2H, $J_{\mathrm{H} 16, \mathrm{H} 17}=$ $6.8 \mathrm{~Hz}, \mathrm{H}-16), 1.35$ (t, 3H, $\left.J_{\mathrm{H} 17, \mathrm{H} 16}=6.8 \mathrm{~Hz}, \mathrm{H}-17\right) ;{ }^{13} \mathrm{C} \mathrm{NMR}$ (50 MHz, $300 \mathrm{~K}, \mathrm{~d}_{6}$-DMSO) $\delta 172.2$ (C-7), 163.6 (C-2), 155.3 (C-4), 146.6 (C-12), 144.1 (C-11), 131.4 (C-6), 125.7 (C-10), 120.3 (C-14), 119.2 (C-15), 111.8 (C-13), 105.8 (C-1), 100.2 (C-5), 96.7 (C-3), 64.4 (C-16), 40.8 (C-9), 15.0 (C-17); Anal. Calcd. For $\mathrm{C}_{16} \mathrm{H}_{17} \mathrm{NO}_{5}$ : C, 63.36; $\mathrm{H}, 4.62 ; \mathrm{N}, 5.65$. Found: C, 63.51; $\mathrm{H}, 4.48$; N, 5.66.

4.1.5. Synthesis of Substituted-dihydroxy-di-carboxylic Acids 16 and 17. According to the previously reported general procedures [23-26], the appropriate substituted phenol was used in the synthesis substituted-dihydroxy-di-carboxylic acids 16 and 17.

\subsubsection{Synthesis of 7-N-Substituted-amino-1,3-oxazines $\mathbf{1 0 a}, \boldsymbol{b}$, and $11 a, b$, and $d$}

General Procedure B. The substituted-2-hydroxy benzoic acid was allowed to react with the freshly prepared $\mathrm{Ph}_{3} \mathrm{P}(\mathrm{SCN})_{2}$ according to previously reported general procedure $[22,34]$.

N-(4-Oxo-2-thioxo-3,4-dihydro-2H-benz[e][1,3]oxazin-7-yl) acetamide 10a. Slightly modified to the previously reported general procedure B $[22,34]$, 4-(acetyl amino)-2hydroxybenzoic acid $\mathbf{8 a}(1.56 \mathrm{~g}, 8 \mathrm{mmol})$ was allowed to react with freshly prepared $\mathrm{Ph}_{3} \mathrm{P}(\mathrm{SCN})_{2}(10 \mathrm{mmol})$ at room temperature for 2 hours then under reflux for 16 hours. At the completion of the reaction, the $\mathrm{PbBr}_{2}$ filter cake was washed by acetic acid $(150 \mathrm{~mL})$ to extract the desired product. The acetic acid filtrate was evaporated and minimal toluene was added to dissolve any oil with the product. The crude solid was filtered and recrystallised from ethanol to give 10a $(1.22 \mathrm{~g}, 65 \%)$ as light red crystals, mp $285-287^{\circ} \mathrm{C}$ decomp. $v_{\max }(\mathrm{KBr}) / \mathrm{cm}^{-1}$ 3290, 3183 (9-NH), 3072, 2923 (3-NH), $1704(\mathrm{C}=\mathrm{O}), 1188(\mathrm{C}=\mathrm{S})$; ${ }^{1} \mathrm{HNMR}(200 \mathrm{MHz}, 390 \mathrm{~K}$, $\mathrm{d}_{6}$-DMSO) $\delta 13.38$ (bs, 1H, 9-NH), 10.56 (s, 1H, 3-NH), 7.86 $\left(\mathrm{d}, 1 \mathrm{H}, J_{\mathrm{H} 5, \mathrm{H} 6}=8.6 \mathrm{~Hz}, \mathrm{H}-5\right), 7.77\left(\mathrm{~d}, 1 \mathrm{H}, J_{\mathrm{H} 8, \mathrm{H} 6}=1.8 \mathrm{~Hz}\right.$, $\mathrm{H}-8), 7.44\left(\mathrm{dd}, 1 \mathrm{H}, J_{\mathrm{H} 6, \mathrm{H} 5}=8.6 \mathrm{~Hz}, J_{\mathrm{H} 6, \mathrm{H} 8}=1.8 \mathrm{~Hz}, \mathrm{H}-6\right)$, 2.11 (s, 3H, 11- $\left.\mathrm{CH}_{3}\right) ;{ }^{13} \mathrm{C}$ NMR $\left(50 \mathrm{MHz}, 330 \mathrm{~K}, \mathrm{~d}_{6}\right.$-DMSO) $\delta 181.9$ (C-2), 169.2 (C-10), 156.7 (C-8a), 146.0 (C-7), 127.3 (C-5), 116.3 (C-6), 109.6 (C-4a), 104.2 (C-8), 24.0 (C-11) 155.9 (C-4); Anal. Calcd. For $\mathrm{C}_{10} \mathrm{H}_{8} \mathrm{~N}_{2} \mathrm{O}_{3} \mathrm{~S}$ : C, 50.84; H, 3.41; N, 11.86 C. Found: C, 50.69; H, 3.53; N, 11.86.

Synthesis of 7-Amino-2-thioxo-2H-benz[e][1,3]oxazin-4(3H)one 10b. A suspension of (E)-4-((3-ethoxy-2-hydroxybenzylidene)amino)-2-hydroxybenzoic acid 8d (1.2 g, $4 \mathrm{mmol}$ ) in dry DCM $(20 \mathrm{~mL})$ was added to a mixture of freshly prepared $\mathrm{Ph}_{3} \mathrm{P}(\mathrm{SCN})_{2}(10 \mathrm{mmol})$ according to the general procedure B. The resulting solid was isolated upon evaporation of the DCM filtrate 10b $(0.74 \mathrm{~g}, 91 \%$ crude yield $)$. The solid was recrystallised from methanol, $\mathrm{mp} 250-253^{\circ} \mathrm{C}$ decomp. $\nu_{\max }$ $(\mathrm{KBr}) \mathrm{cm}^{-1}$ 3443, 3328, $\left(\mathrm{NH}_{2}\right), 3059,2916(\mathrm{NH}), 1749(\mathrm{C}=\mathrm{O})$, 1679, $1616(\mathrm{C}=\mathrm{C}), 1205(\mathrm{C}=\mathrm{S}) ;{ }^{1} \mathrm{HNMR}\left(200 \mathrm{MHz}, 370 \mathrm{~K}, \mathrm{~d}_{6^{-}}\right.$ DMSO) $\delta 13.04(\mathrm{~s}, 1 \mathrm{H}, 3-\mathrm{NH}), 7.58\left(\mathrm{~d}, 1 \mathrm{H}, J_{\mathrm{H} 5, \mathrm{H} 6}=8.6 \mathrm{~Hz}\right.$, $\mathrm{H}-5), 6.65$ (s, 2H, 7- $\left.\mathrm{NH}_{2}\right), 6.60\left(\mathrm{dd}, 1 \mathrm{H}, J_{\mathrm{H} 6, \mathrm{H} 5}=8.6 \mathrm{~Hz}\right.$, $\left.J_{\mathrm{H} 6, \mathrm{H} 8}=1.8 \mathrm{~Hz}, \mathrm{H}-6\right), 6.37\left(\mathrm{~d}, 1 \mathrm{H}, J_{\mathrm{H} 8, \mathrm{H} 6}=1.8 \mathrm{~Hz}\right) ;{ }^{13} \mathrm{C} \mathrm{NMR}$ $\left(50 \mathrm{MHz}, 330 \mathrm{~K}, \mathrm{~d}_{6}\right.$-DMSO) $\delta 182.4$ (C-2), 157.3, 156.9, 156.5 (C-4, C-8a, C-7), 128.1 (C-5), 112.7 (C-6), 102.3 (C-4a), 96.8 (C-8); Anal. Calcd. For $\mathrm{C}_{8} \mathrm{H}_{6} \mathrm{~N}_{2} \mathrm{O}_{2} \mathrm{~S}$ : C, 49.47; H, 3.11; N, 14.42. Found: C, 49.51; H, 3.20; N, 14.36.

7-(Benzylamino)-2-thioxo-2H-benz[e][1,3]oxazin-4(3H)-one 11a. In slight modification to previously reported general procedure B, 4-(benzylamino)-2-hydroxybenzoic acid 9a $(0.94 \mathrm{~g}, 4 \mathrm{mmol})$ was allowed to react with the freshly prepared $\mathrm{Ph}_{3} \mathrm{P}(\mathrm{SCN})_{2}(10 \mathrm{mmol})$ at room temperature for 2 hours then under reflux for 16 hours. The resulting crude solids $(0.94 \mathrm{~g}, 82 \%)$ were filtered, collected, and recrystallised from toluene to give $11 \mathrm{a}(0.88 \mathrm{~g}, 77 \%)$ as yellow crystals, $\mathrm{mp}$ 210-212 ${ }^{\circ} \mathrm{C}$ decomp. $v_{\max }(\mathrm{KBr}) / \mathrm{cm}^{-1} 3301(9-\mathrm{NH}) 3068,2926$ (3-NH), 1689 (C=O), 1197 (C=S); ${ }^{1} \operatorname{HNMR}(200 \mathrm{MHz}, 340 \mathrm{~K}$, $\mathrm{d}_{6}$-DMSO) $\delta 12.90$ (bs, $1 \mathrm{H}, 3-\mathrm{NH}$ exchangeable with $\mathrm{D}_{2} \mathrm{O}$ ), $7.61\left(\mathrm{~d}, 1 \mathrm{H}, J_{\mathrm{H} 5, \mathrm{H} 6}=8.8 \mathrm{~Hz}, \mathrm{H}-5\right), 7.37-7.26(\mathrm{~m}, 6 \mathrm{H}, \mathrm{Ar}$ and 9- $\mathrm{NH}$ exchangeable with $\left.\mathrm{D}_{2} \mathrm{O}\right), 6.73\left(\mathrm{dd}, 1 \mathrm{H}, J_{\mathrm{H} 6, \mathrm{H} 5}=8.8 \mathrm{~Hz}\right.$, $\left.J_{\mathrm{H} 6, \mathrm{H} 8}=2.0 \mathrm{~Hz}, \mathrm{H}-6\right), 6.42\left(\mathrm{~d}, 1 \mathrm{H}, J_{\mathrm{H} 8, \mathrm{H} 6}=2.0 \mathrm{~Hz}, \mathrm{H}-8\right), 4.41$ $\left(\mathrm{d}, 2 \mathrm{H}, J_{\mathrm{H} 10, \mathrm{H} 9}=5.9 \mathrm{~Hz}, \mathrm{H}-10\right) ;{ }^{13} \mathrm{C}$ NMR $(50 \mathrm{MHz}, 340 \mathrm{~K}$, $\mathrm{d}_{6}$-DMSO) $\delta 182.1$ (C-2), 157.2, 156.5 (C-4, C-8a), 155.2 (C-7), 138.2 (C-11), (128.2, 127.3, 127.0, 126.8), (C-13, C-12, C-14 and C-5), 111.9 (C-6), 102.5 (C-4a), 95.1 (C-8), 45.8 (C-10); Anal. Calcd. For $\mathrm{C}_{15} \mathrm{H}_{12} \mathrm{~N}_{2} \mathrm{O}_{2} \mathrm{~S}$ : C, 59.99; H, 4.03; N, 9.33. Found: C, 59.83; H, 4.14; N, 9.45.

7-((2-Hydroxybenzyl)amino)-2-thioxo-2H-benz[e][1,3]oxazin-4(3H)-one $\mathbf{1 1 b}$. In slight modification to previously reported general procedure B, 2-hydroxy-4-((2-hydroxybenzyl)amino)benzoic acid 9b (1.07 g, $4 \mathrm{mmol})$ was allowed to react with the freshly prepared $\mathrm{Ph}_{3} \mathrm{P}(\mathrm{SCN})_{2}(10 \mathrm{mmol})$ at room temperature for 2 hours then under reflux for 16 hours. The resulting crude solid recrystallised from acetonitrile to give $11 \mathrm{~b}(0.55 \mathrm{~g}, 46 \%)$ as yellow crystals, $\mathrm{mp} 173-175^{\circ} \mathrm{C}$ decomp. $v_{\max }(\mathrm{KBr}) / \mathrm{cm}^{-1} 3500-3000$ br $(\mathrm{OH}), 3310(9-\mathrm{NH})$, 2926 (3-NH), $1684(\mathrm{C}=\mathrm{O}), 1192(\mathrm{C}=\mathrm{S}) ;{ }^{1} \mathrm{HNMR}(200 \mathrm{MHz}$, $340 \mathrm{~K}, \mathrm{~d}_{6}$-DMSO) $\delta 12.86$ (bs, $1 \mathrm{H}, 3-\mathrm{NH}$ ), 9.50 (bs, $1 \mathrm{H}$, $12-\mathrm{OH}), 7.59$ (d, $\left.1 \mathrm{H}, J_{\mathrm{H} 5, \mathrm{H} 6}=8.6 \mathrm{~Hz}, \mathrm{H}-5\right), 7.41$ (bs, $1 \mathrm{H}$, 9-NH), 7.05-7.20 (m, 2H, H-14, H-16), 6.69-6.88 (m, 3H, $\mathrm{H}-13, \mathrm{H}-15$ and H-6), 6.42 (d, $\left.1 \mathrm{H}, J_{\mathrm{H} 8, \mathrm{H} 6}=2.0 \mathrm{~Hz}, \mathrm{H}-8\right), 4.32$ (s, 2H, H-10); ${ }^{13} \mathrm{C}$ NMR (50 MHz, 340 K, d 6 -DMSO) $\delta 182.2$ (C-2), 157.3, 156.7, 155.4, 154.9 (C-4, C-8a, C-12 and C-7), 128.5, 127.9, 127.3 (C-14, C-16 and C-5) 123.9 (C-11), 118.8, 115.1 C-15, C-13), 111.9 (C-6), 102.2 (C-4a), 94.9 (C-8), 40.9 (C-10); Anal. Calcd. For $\mathrm{C}_{15} \mathrm{H}_{12} \mathrm{~N}_{2} \mathrm{O}_{3}$ : C, 59.99; H, 4.03; N, 9.33 Found: C, 59.83; H, 4.14; N, 9.45.

7-((3-Ethoxy-2-hydroxybenzyl)amino)-2-thioxo-2H-benz[e] $[1,3]$ oxazin-4(3H)-one 11c. In slight modification to 
previously reported general procedure [22, 34], 4-((3ethoxy-2-hydroxybenzyl)amino)-2-hydroxybenzoic acid 9d $(1.21 \mathrm{~g}, 4 \mathrm{mmol})$ was allowed to react with the freshly prepared $\mathrm{Ph}_{3} \mathrm{P}(\mathrm{SCN})_{2}$ (10 mmol) heated to room temperature for 2 hours then under reflux for 16 hours. The resulting solids $(1.94 \mathrm{~g})$ were recrystallised from acetic acid/water to give $11 \mathrm{c}(0.95 \mathrm{~g}, 68 \%)$ as yellow crystals, $\mathrm{mp} 227-229^{\circ} \mathrm{C}$ decomp. $v_{\max }(\mathrm{KBr}) / \mathrm{cm}^{-1} 3500-3200$ br $(\mathrm{OH}), 3496(7-\mathrm{NH}), 3301$ (3-NH), $1686(\mathrm{C}=\mathrm{O}), 1620(\mathrm{C}=\mathrm{C}), 1196(\mathrm{C}=\mathrm{S}) ;{ }^{1} \mathrm{HNMR}$ $\left(200 \mathrm{MHz}, 390 \mathrm{~K}, \mathrm{~d}_{6}\right.$-DMSO) $\delta 12.86$ (bs, $\left.1 \mathrm{H}, 3-\mathrm{NH}\right), 8.44$ $\left(\mathrm{s}, 1 \mathrm{H}, 12-\mathrm{OH}\right.$ exchangeable with $\left.\mathrm{D}_{2} \mathrm{O}\right), 7.59\left(\mathrm{~d}, 1 \mathrm{H}, \mathrm{J}_{\mathrm{H} 5, \mathrm{H} 6}=\right.$ $8.4 \mathrm{~Hz}, \mathrm{H}-5), 7.42(\mathrm{t}, 1 \mathrm{H}, 9-\mathrm{NH}) 6.89-6.40(\mathrm{~m}, 4 \mathrm{H}, \mathrm{Ar}$ and $\mathrm{H}-6), 6.41\left(\mathrm{~d}, 1 \mathrm{H}, J_{\mathrm{H} 8, \mathrm{H} 6}=1.8 \mathrm{~Hz}, \mathrm{H}-8\right), 4.33\left(\mathrm{~d}, 2 \mathrm{H}, 10-\mathrm{CH}_{2}\right)$, $4.07\left(\mathrm{q}, 2 \mathrm{H}, J_{\mathrm{H} 17, \mathrm{H} 18}=7.0 \mathrm{~Hz}, 17-\mathrm{CH}_{2}\right), 1.36\left(\mathrm{t}, 3 \mathrm{H}, J_{\mathrm{H} 18, \mathrm{H} 17}\right.$ $\left.=7.0 \mathrm{~Hz}, 18-\mathrm{CH}_{3}\right) ;{ }^{13} \mathrm{C}$ NMR $\left(50 \mathrm{MHz}, 390 \mathrm{~K}, \mathrm{~d}_{6}\right.$-DMSO $\delta$ 181.8 (C-2), 156.9, 156.1, 155.2 (C-4, C-8a, C-7), 146.2, 144.2 (C-13, C-12), 126.9, 124.4 (C-15, C-11), 120.2, 118.4 (C-5, C-16), 112.2, 111.5 (C-14, C-6), 102.1 (C-4a), 94.8 (C-8), 64.2 (C-17), 40.7 (C-10), 14.0 (C-18); Anal. Calcd. For $\mathrm{C}_{15} \mathrm{H}_{12} \mathrm{~N}_{2} \mathrm{O}_{2} \mathrm{~S}$ : C, 59.29; H, 4.68. Found: C, 59.07; H, 4.70.

\subsubsection{Synthesis of Dithioxo-benz-bis-(1,3-oxazine)-diones $18 a-c$ and 19}

2,8-Dithioxo-2,3,7,8-tetrahydrobenzo[1,2-e: 5,4-e']bis([1,3]oxazine)-4,6-dione 18a. In slight modification to the general procedure B, 4,6-dihydroxyisophthalic acid $16 \mathrm{a}(0.79 \mathrm{~g}$, $4 \mathrm{mmol}$ ) was allowed to react with the freshly prepared $\mathrm{Ph}_{3} \mathrm{P}(\mathrm{SCN})_{2}(10 \mathrm{mmol})$ heated to room temperature for 3 hours then under reflux for 5 hours. At the completion of the reaction, the reaction mixture was filtered and the $\mathrm{PbBr}_{2}$ filter cake washed with THF $(100 \mathrm{~mL})$ to extract product 18a. Both THF and DCM filtrates were evaporated to dryness and minimal toluene added to remove any oil which may be present. The crude solid was recrystallised using dioxane/chloroform to give 18a $(0.63 \mathrm{~g}, 56 \%)$ as yellow crystals, $\mathrm{mp}>300^{\circ} \mathrm{C}$ decomp. $v_{\max }(\mathrm{KBr}) / \mathrm{cm}^{-1} 3104,3031,2939,2856$ (3 and 7-NH), $1698(\mathrm{C}=\mathrm{O}), 1152(\mathrm{C}=\mathrm{S}) ;{ }^{1} \mathrm{HNMR}(200 \mathrm{MHz}$, $350 \mathrm{~K} \mathrm{~d}_{6}$-DMSO) $\delta 13.65$ (bs, $2 \mathrm{H}, 2 \times \mathrm{NH}$ ), 8.27 (bs, $1 \mathrm{H}, \mathrm{H}-$ 5), 7.69 (bs, $1 \mathrm{H}, \mathrm{H}-10) ;{ }^{13} \mathrm{C}$ NMR (50 MHz, $\mathrm{d}_{6}$-DMSO) $\delta 181.1$ (C-2,8), 159.0 (C-4,6), 156.1 (C-9a,10a), 126.5 (C-5), 113.8 (C4a,5a), 104.1 (C-10); Anal. Calcd. For $\mathrm{C}_{10} \mathrm{H}_{4} \mathrm{~N}_{4} \mathrm{O}_{4} \mathrm{~S}_{2}$ : C, 42.85; H, 1.44; N, 9.99. Found: C, 42.71; H, 1.48; N, 10.05 .

10-Hydroxy-2,8-dithioxo-2,3,7,8-tetrahydrobenzo[1,2-e: 5,4$\left.e^{\prime}\right]$ bis([1,3]oxazine)-4,6-dione 18b. In slight modification to general procedure B, 4,5,6-trihydroxyisophthalic acid $\mathbf{1 6 b}$ $(0.86 \mathrm{~g}, 4 \mathrm{mmol})$ was allowed to react with the freshly prepared $\mathrm{Ph}_{3} \mathrm{P}(\mathrm{SCN})_{2}(10 \mathrm{mmol})$ at room temperature for 3 hours and then under reflux for 5 hours. At the completion of the reaction, the mixture was filtered and the $\mathrm{PbBr}_{2}$ cake washed with $100 \mathrm{~mL}$ 1,4-dioxane. Both dioxane and DCM filtrates were evaporated to dryness under reduced pressure and minimal toluene was added to remove any oil which may be present. The resulting solid was recrystallised from 1, 4 dioxane/chloroform to give $\mathbf{1 8 b}(0.55 \mathrm{~g}, 46 \%)$ as yellow crystals, mp $286-289^{\circ} \mathrm{C}$ decomp. $v_{\max }(\mathrm{KBr}) / \mathrm{cm}^{-1} 3300-$ 3000 br $(\mathrm{OH}), 3103,3047,2938(\mathrm{NH}), 1698(\mathrm{C}=\mathrm{O}), 1227$ $(\mathrm{C}=\mathrm{S}) ;{ }^{1} \mathrm{H}$ NMR $\left(200 \mathrm{MHz}, 390 \mathrm{~K} \mathrm{~d}_{6}\right.$-DMSO) $\delta 13.69$ (bs, $2 \mathrm{H}$, $2 \times \mathrm{NH}$ ), 11.64 (bs, $1 \mathrm{H}, \mathrm{OH}$ ), 7.80 (bs, $1 \mathrm{H}, \mathrm{H}-5$ ); ${ }^{13} \mathrm{CNMR}$ $\left(50 \mathrm{MHz}, 390 \mathrm{~K} \mathrm{~d}_{6}-\mathrm{DMSO}\right) \delta 181.0(\mathrm{C}-2,8), 156.8(\mathrm{C}-4,6)$, 148.6 (C-9a,10a), 131.9 (C-10), 113.8 (C-5), 113.8 (C-4a,5a); Anal. Calcd. For $\mathrm{C}_{10} \mathrm{H}_{4} \mathrm{~N}_{4} \mathrm{O}_{4} \mathrm{~S}_{2}$ : C, 42.85; H, 1.44; N, 9.99. Found: C, 42.71; H,1.48; N, 10.05 .

10-Methyl-2,8-dithioxo-2,3,7,8-tetrahydrobenzo[1,2-e: 5,4-e'] bis([1,3]oxazine)-4,6-dione 18c. In slight modification to general procedure B, 4,6-dihydroxy-5-methylisophthalic acid $16 \mathrm{c}(1.7 \mathrm{~g}, 8 \mathrm{mmol})$ was allowed to react with freshly prepared $\mathrm{Ph}_{3} \mathrm{P}(\mathrm{SCN})_{2}[22,34](10 \mathrm{mmol})$ at room temperature for 3 hours then under reflux for 5 hours. At the completion of the reaction, the reaction mixture was filtered and the $\mathrm{PbBr}_{2}$ cake washed with approx $100 \mathrm{~mL}$ THF and filtered. Both THF and DCM filtrates were evaporated to dryness under reduced pressure and minimal toluene was added to remove any oil, which may be present. The solid which remained was then recrystallised using THF to give product $18 \mathrm{c}(1.18 \mathrm{~g}, 50 \%)$. The physical and spectroscopic data is consistent with the literature values [22].

2,9-Dithioxo-2,3,8,9-tetrahydrobenzo[1,2-e:4,3-e']bis([1,3]oxazine)-4,7-dione 19. In slight modification to the general procedure B $[22,34], 2,3$-dihydroxyterephthalic acid $17(0.86 \mathrm{~g}, 4 \mathrm{mmol})$ was allowed to react with freshly prepared $\mathrm{Ph}_{3} \mathrm{P}(\mathrm{SCN})_{2}(10 \mathrm{mmol})$ at room temperature for 3 hours then under reflux for 5 hours. At the completion of the reaction, the reaction mixture was filtered and the $\mathrm{PbBr}_{2}$ cake was washed with THF $(100 \mathrm{~mL})$. Both THF and DCM filtrates were evaporated to dryness under reduced pressure and minimal toluene was added to remove any oil, which may be present. The remaining solid is recrystallised from ethyl acetate to give $19(0.54 \mathrm{~g}, 50 \%)$ as yellow crystals, $\mathrm{mp}>$ $300^{\circ} \mathrm{C}$ decomp. $v_{\max }(\mathrm{KBr}) / \mathrm{cm}^{-1} 3079,2904,2864(\mathrm{NH}), 1718$ $(\mathrm{C}=\mathrm{O}), 1252(\mathrm{C}=\mathrm{S}) ;{ }^{1} \mathrm{H}$ NMR $\left(200 \mathrm{MHz}, 390 \mathrm{~K} \mathrm{~d}_{6}\right.$-DMSO) $\delta 13.90$ (bs, 2H, $2 \times \mathrm{NH}$ ), 7.89 (s, 2H, H-5 \& H-6); ${ }^{13} \mathrm{C}$ NMR $\left(50 \mathrm{MHz}, 390 \mathrm{~K}\left(\mathrm{~d}_{6}-\mathrm{DMSO}\right) \delta 181.1(\mathrm{C}-2,9), 157.0\right.$ (C-4,7), 142.7 (C-10a,10b), 122.5 (C-5,6), 121.3 (C-4a,6a); Anal. Calcd. For $\mathrm{C}_{10} \mathrm{H}_{4} \mathrm{~N}_{2} \mathrm{O}_{4} \mathrm{~S}_{2}: \mathrm{C}, 42.85 ; \mathrm{H}, 1.44 ; \mathrm{N}, 9.99$. Found: $\mathrm{C}, 42.74$; $\mathrm{H}, 1.50 ; \mathrm{N}, 9.93$.

\subsubsection{Synthesis of Benzyl Thiourea $\mathbf{1 3 a - q}$}

General Procedure C. The appropriate 2-thio-1,3-benzoxazines (1.7 mmole) $\mathbf{6}, \mathbf{1 0 a}, \mathbf{b}, \mathbf{1 1 c}$, and $\mathbf{1 2 a}-\mathbf{m}$ were suspended in a mixture of sodium bicarbonate $(1 \mathrm{gm})$ and water $(5 \mathrm{~mL}) /$ methanol $(5 \mathrm{~mL})$ with stirring, then the reaction mixture was warm to $40^{\circ} \mathrm{C}$ for few minutes then benzyl amine $(4.25 \mathrm{mmol})$ was added dropwise, directly from the a pipette, left stirring at room temperature for 4 hours. At the completion of the reaction, the mixture was evaporated to dryness under reduced pressure and the $\mathrm{pH}$ was adjusted to $5-6$ by using conc. $\mathrm{HCl}$. The resulting solid was collected 
by vacuum filtration and washed with minimal water and recrystallized from an appropriate solvent.

$N$-(Benzyl carbamothioyl)-2-hydroxybenzamide 13a. 2-Thioxo-2H-benz[e]-1,3-oxazin-4(3H)-one 12a was allowed to react with benzyl amine according to general procedure $C$. The crude solid was collected and recrystallized from toluene to give 13a (75\% yield), mp $176-177^{\circ} \mathrm{C}$ (Lit. $\left.[19,20] 179^{\circ} \mathrm{C}\right)$. $\nu_{\max }(\mathrm{KBr}) / \mathrm{cm}^{-1} 3301(\mathrm{~N}-\mathrm{H}), 3200-2700(\mathrm{O}-\mathrm{H}), 1661(\mathrm{C}=\mathrm{O})$, 1605 (C=S); ${ }^{1} \mathrm{H}$ NMR (d -DMSO$\delta 12.42$ (bs, $\left.1 \mathrm{H}, \mathrm{H}-2^{\prime}\right), 11.41$ (s, 1H, O-H), $11.00\left(\mathrm{t}, 1 \mathrm{H}, J=5.4 \mathrm{~Hz}, \mathrm{H}-4^{\prime}\right), 7.70-7.00(\mathrm{~m}, 9 \mathrm{H}$, $\mathrm{ArH}), 4.9\left(\mathrm{~d}, 2 \mathrm{H}, J=5.2 \mathrm{~Hz}, \mathrm{H}-5^{\prime}\right) ;{ }^{13} \mathrm{C} \mathrm{NMR}\left(\mathrm{d}_{6}\right.$-DMSO) $\delta$ $179.6\left(\mathrm{C}-3^{\prime}\right), 168.3\left(\mathrm{C}-1^{\prime}\right), 160.7(\mathrm{C}-2), 136.3\left({\mathrm{C}-6^{\prime}}^{\prime}\right), 135.9(\mathrm{C}-$

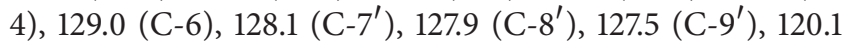
(C-5), 118.8 (C-3), 113.3 (C-1), $50.0\left(\mathrm{C}-5^{\prime}\right)$.

$N$-(Benzyl carbamothioyl)-2-hydroxy-3-methylbenzamide 13b. 8-Methyl-2-thioxo-2H-benz[e]-1,3-oxazin-4(3H)-one 12b was allowed to react with benzyl amine according to general procedure $\mathrm{C}$. The crude solid was collected and recrystallized from toluene to give $\mathbf{1 3 b}$ (79\% yield), mp $220-223^{\circ} \mathrm{C}$. $\nu_{\max }(\mathrm{KBr}) / \mathrm{cm}^{-1} 3062,2883(\mathrm{~N}-\mathrm{H}), 1696(\mathrm{C}=\mathrm{O}), 1610(\mathrm{C}=\mathrm{S})$; ${ }^{1} \mathrm{H}$ NMR ( $\mathrm{d}_{6}$-DMSO) $\delta 11.32$ (bs, $\left.1 \mathrm{H}, \mathrm{H}-2^{\prime}\right), 10.73$ (s, $1 \mathrm{H}$, $\mathrm{O}-\mathrm{H}), 8.80\left(\mathrm{t}, 1 \mathrm{H}, J=5.4 \mathrm{~Hz}, \mathrm{H}-4^{\prime}\right), 7.82(\mathrm{~d}, 1 \mathrm{H}, J=7.5 \mathrm{~Hz}$, H-6), 7.40-7.20 (m, ArH, H-4), 6.8 (t, 1H, $J=7.5$ Hz, H-5), $4.43\left(\mathrm{~d}, 2 \mathrm{H}, J=6.0 \mathrm{~Hz}, \mathrm{H}-5^{\prime}\right), 2.20\left(\mathrm{~s}, 3 \mathrm{H}, 8-\mathrm{CH}_{3}\right) ;{ }^{13} \mathrm{C} \mathrm{NMR}$ $\left(\mathrm{d}_{6}\right.$-DMSO) $\delta 169.9\left(\mathrm{C}-3^{\prime}\right), 157.7\left(\mathrm{C}-1^{\prime}\right), 152.9(\mathrm{C}-2), 137.5$ $\left(\mathrm{C}-6^{\prime}\right), 136.0(\mathrm{C}-4), 128.4\left(\mathrm{C}-7^{\prime}\right), 127.3\left(\mathrm{C}-8^{\prime}\right), 127.0\left(\mathrm{C}-9^{\prime}\right)$, 126.9 (C-3), 126.5 (C-6), 119.0 (C-5), 115.1 (C-1), 42.9 (C-5'), $15.9\left(\mathrm{CH}_{3}\right)$; Anal. Calcd. For $\mathrm{C}_{16} \mathrm{H}_{16} \mathrm{~N}_{2} \mathrm{O}_{3}$ : C, 67.59; H, 5.67; N, 9.85. Found: C, 67.10; H, 5.38; N, 9.25.

N-(Benzyl carbamothioyl)-2-hydroxy-[1,1'-biphenyl]-3-carboxamide 13c. 8-Phenyl-2-thioxo-2H-benz[e]-1,3-oxazin$4(3 H)$-one $12 \mathrm{c}$ was allowed to react with benzyl amine according to general procedure $\mathrm{C}$. The crude solid was collected and recrystallized from toluene to give $13 \mathrm{c}(80 \%$ yield), mp $250-253^{\circ} \mathrm{C} . \nu_{\max }(\mathrm{KBr}) / \mathrm{cm}^{-1} 3062,2883(\mathrm{~N}-\mathrm{H})$, $1686(\mathrm{C}=\mathrm{O}), 1595(\mathrm{C}=\mathrm{S}) ;{ }^{1} \mathrm{H}$ NMR $\left(\mathrm{d}_{6}\right.$-DMSO) $\delta 11.30(\mathrm{~s}, 1 \mathrm{H}$, $\left.2^{\prime}-\mathrm{N}-\mathrm{H}\right), 10.70(\mathrm{~s}, 1 \mathrm{H}, \mathrm{O}-\mathrm{H}), 8.80\left(\mathrm{t}, 1 \mathrm{H}, J=5.4 \mathrm{~Hz}, 4^{\prime}-\mathrm{N}-\mathrm{H}\right)$, $7.90(\mathrm{~d}, 1 \mathrm{H}, J=7.6 \mathrm{~Hz}, \mathrm{H}-6), 7.80(\mathrm{~d}, 1 \mathrm{H}, J=7.6 \mathrm{~Hz}, \mathrm{H}-4)$, $7.60\left(\mathrm{dd}, 1 \mathrm{H}, J_{\mathrm{H} 8, \mathrm{H} 10}=1.6 \mathrm{~Hz}, J_{\mathrm{H} 8, \mathrm{H} 9}=8.0 \mathrm{~Hz}, \mathrm{H}-8\right), 7.50(\mathrm{~m}$, 4H, H-5/H-9/H-10), 7.30-7.20 (m, ArH, H-4), 4.90 (d, 2H, J $\left.=6.0 \mathrm{~Hz}, \mathrm{H}-5^{\prime}\right) ;{ }^{13} \mathrm{C} \mathrm{NMR}\left(\mathrm{d}_{6}\right.$-DMSO) $\delta 169.4\left(\mathrm{C}-3^{\prime}\right), 157.7$ $\left(\mathrm{C}-1^{\prime}\right), 155.3(\mathrm{C}-2), 137.2\left({\mathrm{C}-6^{\prime}}^{\prime}\right), 134.2$ (C-4), 129.5 (C-6), 128.4 $\left(\mathrm{C}-7^{\prime}\right), 127.3\left(\mathrm{C}-8^{\prime}\right), 127.0\left(\mathrm{C}-9^{\prime}\right), 126.3(\mathrm{C}-3), 120.1(\mathrm{C}-1), 118.9$ (C-5), 50.1 (C-5'); Anal. Calcd. For $\mathrm{C}_{15} \mathrm{H}_{14} \mathrm{~N}_{2} \mathrm{O}_{2} \mathrm{~S}$ : C, 62.92; $\mathrm{H}, 4.93 ; \mathrm{N}, 9.78$. Found: C, 63.03; H, 4.88; N, 9.80.

N-(Benzyl carbamothioyl)-5-bromo-2-hydroxybenzamide 13d. 6-Bromo-2-thioxo-2H-benz[e]-1,3-oxazin-4(3H)-one 12d was allowed to react with benzyl amine according to general procedure $\mathrm{C}$. The crude solid was collected and recrystallized from toluene to give $13 \mathbf{d}$ ( $82 \%$ yield), $\mathrm{mp} 185^{\circ} \mathrm{C}$. $v_{\max }(\mathrm{KBr}) / \mathrm{cm}^{-1} 3296,3073(\mathrm{~N}-\mathrm{H}), 1678(\mathrm{C}=\mathrm{O}), 1601(\mathrm{C}=\mathrm{S})$; ${ }^{1} \mathrm{H} \mathrm{NMR}\left(\mathrm{d}_{6}\right.$-DMSO) $\delta 12.42$ (bs, $\left.1 \mathrm{H}, \mathrm{H}-2^{\prime}\right), 11.41(\mathrm{~s}, 1 \mathrm{H}$, $\mathrm{O}-\mathrm{H}), 11.00\left(\mathrm{t}, 1 \mathrm{H}, J=5.4 \mathrm{~Hz}, \mathrm{H}-4^{\prime}\right), 7.90(\mathrm{~d}, 1 \mathrm{H}, J=2.2 \mathrm{~Hz}$, $\mathrm{H}-6), 7.60\left(\mathrm{dd}, 1 \mathrm{H}, J_{\mathrm{H} 4, \mathrm{H} 6}=2.2 \mathrm{~Hz}, J_{\mathrm{H} 4, \mathrm{H} 3}=7.5 \mathrm{~Hz}, \mathrm{H}-4\right)$, 7.40-7.30 (m, 5H, ArH), 7.00 (d, 1H, J = 7.5 Hz, H-3), 4.90 $\left(\mathrm{d}, 2 \mathrm{H}, J=5.5 \mathrm{~Hz}, \mathrm{H}-5^{\prime}\right) ;{ }^{13} \mathrm{C} \mathrm{NMR}\left(\mathrm{d}_{6}\right.$-DMSO) $\delta 179.4$ $\left(\mathrm{C}-3^{\prime}\right), 163.3\left(\mathrm{C}-1^{\prime}\right), 155.9(\mathrm{C}-2), 137.4(\mathrm{C}-4), 137.3\left(\mathrm{C}-6^{\prime}\right)$,

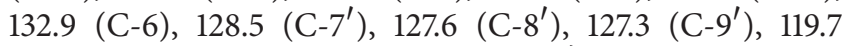
(C-1), 118.8 (C-3), 111.1 (C-5), 48.3 (C-5'); Anal. Calcd. For $\mathrm{C}_{15} \mathrm{H}_{13} \mathrm{BrN}_{2} \mathrm{O}_{2} \mathrm{~S}$ : C, 49.33; H, 3.59; N, 7.67. Found: C, 49.39; $\mathrm{H}, 3.68$; N, 7.93.

$N$-(Benzyl carbamothioyl)-5-ethoxy-2-hydroxybenzamide $\mathbf{1 3 e}$. 6-Ethoxy-2-thioxo-2H-benz[e]-1,3-oxazin-4(3H)-one $\mathbf{1 2 e}$ was allowed to react with benzyl amine according to general procedure $\mathrm{C}$. The crude solid was collected and recrystallized from toluene to give $13 \mathbf{e}\left(87 \%\right.$ yield), $\mathrm{mp} 210^{\circ} \mathrm{C} . v_{\max }$ $(\mathrm{KBr}) / \mathrm{cm}^{-1}$ 3300, $3051(\mathrm{~N}-\mathrm{H}), 1665(\mathrm{C}=\mathrm{O}), 1630(\mathrm{C}=\mathrm{S}) ;{ }^{1} \mathrm{H}$ NMR ( $\mathrm{d}_{6}$-DMSO) $\delta 12.00$ (bs, $\left.1 \mathrm{H}, \mathrm{H}-2^{\prime}\right), 11.32$ (s, $\left.1 \mathrm{H}, \mathrm{O}-\mathrm{H}\right)$, $11.12\left(\mathrm{t}, 1 \mathrm{H}, J=5.4 \mathrm{~Hz}, \mathrm{H}-4^{\prime}\right), 7.50(\mathrm{~s}, 1 \mathrm{H}, \mathrm{H}-6), 7.30-7.10(\mathrm{~m}$, $7 \mathrm{H}, \mathrm{ArH} / \mathrm{H}-3 / \mathrm{H}-4), 4.80$ (d, $\left.2 \mathrm{H}, J=5.5 \mathrm{~Hz}, \mathrm{H}-5^{\prime}\right), 4.10-4.00$ $\left(\mathrm{q}, 2 \mathrm{H}, J=6.7 \mathrm{~Hz}, \mathrm{O}-\mathrm{CH}_{2}\right), 1.30-1.20(\mathrm{t}, 3 \mathrm{H}, J=6.7 \mathrm{~Hz}$, $\left.\mathrm{CH}_{3}\right) ;{ }^{13} \mathrm{C} \mathrm{NMR}\left(\mathrm{d}_{6}\right.$-DMSO) $\delta 179.8\left(\mathrm{C}-3^{\prime}\right), 164.3\left(\mathrm{C}-1^{\prime}\right)$, 164.0 (C-2), 158.3 (C-5), $137.4\left(\mathrm{C}-6^{\prime}\right), 128.5\left(\mathrm{C}-7^{\prime}\right), 127.6$ $\left(\mathrm{C}-8^{\prime}\right), 127.3\left(\mathrm{C}-9^{\prime}\right), 120.2(\mathrm{C}-1), 107.9(\mathrm{C}-3), 107.7$ (C-4), 101.7 (C-6), $63.6\left(\mathrm{O}-\mathrm{CH}_{2}\right), 48.2\left(\mathrm{C}-5^{\prime}\right), 14.5\left(\mathrm{CH}_{3}\right)$; Anal. Calcd. For $\mathrm{C}_{17} \mathrm{H}_{18} \mathrm{~N}_{2} \mathrm{O}_{3} \mathrm{~S}$ : C, 61.80; H, 5.49; N, 8.48. Found: C, 61.90; $\mathrm{H}, 5.55$; N, 8.61.

$N$-(Benzyl carbamothioyl)-4-ethoxy-2-hydroxybenzamide $\mathbf{1 3 f}$. 7-Ethoxy-2-thioxo-2H-benz[e]-1,3-oxazin-4(3H)-one $\mathbf{1 2 f}$ was allowed to react with benzyl amine according to general procedure $\mathrm{C}$. The crude solid was collected and recrystallized from ethyl acetate to give $\mathbf{1 3 f}$ (73\% yield), mp 215-218 ${ }^{\circ} \mathrm{C} . \nu_{\max }(\mathrm{KBr}) / \mathrm{cm}^{-1} 3307,3071(\mathrm{~N}-\mathrm{H}), 1655(\mathrm{C}=\mathrm{O})$, $1506(\mathrm{C}=\mathrm{S}) ;{ }^{1} \mathrm{H}$ NMR $\left(\mathrm{d}_{6}-\mathrm{DMSO}\right) \delta 11.91$ (bs, $\left.1 \mathrm{H}, \mathrm{H}-2^{\prime}\right), 11.00$ (s, 1H, O-H), 10.90 (t, 1H, J = 5.6 Hz, H-4'), 7.80 (d, 1H, J = $8.9 \mathrm{~Hz}, \mathrm{H}-6), 7.30-7.20$ (m, 5H, ArH), 6.60 (d, $1 \mathrm{H}, J=8.9 \mathrm{~Hz}$, H-5), 6.40 (sd, $1 \mathrm{H}, J=1.5 \mathrm{~Hz}, \mathrm{H}-3), 4.80$ (d, $2 \mathrm{H}, J=5.5 \mathrm{~Hz}$, $\left.\mathrm{H}-5^{\prime}\right), 4.10-4.00\left(\mathrm{q}, 2 \mathrm{H}, J=6.7 \mathrm{~Hz}, \mathrm{O}-\mathrm{CH}_{2}\right), 1.30-1.20(\mathrm{t}, 3 \mathrm{H}$, $\left.J=6.7 \mathrm{~Hz}, \mathrm{CH}_{3}\right) ;{ }^{13} \mathrm{C} \mathrm{NMR}\left(\mathrm{d}_{6}\right.$-DMSO) $\delta 179.8\left(\mathrm{C}-3^{\prime}\right), 164.3$ $\left(\mathrm{C}-1^{\prime}\right), 164.0$ (C-4), 158.3 (C-2), $137.4\left(\mathrm{C}-6^{\prime}\right), 130.9$ (C-6), $128.5\left(\mathrm{C}-7^{\prime}\right), 127.6\left(\mathrm{C}-8^{\prime}\right), 127.3\left(\mathrm{C}-9^{\prime}\right), 109.2(\mathrm{C}-5), 107.9(\mathrm{C}-1)$, $101.7(\mathrm{C}-3), 63.6\left(\mathrm{O}-\mathrm{CH}_{2}\right), 48.2\left(\mathrm{C}-5^{\prime}\right), 14.5\left(\mathrm{CH}_{3}\right)$; Anal. Calcd. For $\mathrm{C}_{17} \mathrm{H}_{18} \mathrm{~N}_{2} \mathrm{O}_{3} \mathrm{~S}$ C, 61.80; H, 5.49; N, 8.48. Found: C, 62.02; H, 5.55; N, 8.51.

$N$-(Benzyl carbamothioyl)-3-ethoxy-2-hydroxybenzamide $\mathbf{1 3} \mathbf{g}$. 8-Ethoxy-2-thioxo-2H-benz[e]-1,3-oxazin-4(3H)-one $\mathbf{1 2 g}$ was allowed to react with benzyl amine according to general procedure $\mathrm{C}$. The crude solid was collected and recrystallized from toluene to give $\mathbf{1 3 g}$ ( $82 \%$ yield), $\mathrm{mp} 188-190^{\circ} \mathrm{C}$. $\nu_{\max }(\mathrm{KBr}) / \mathrm{cm}^{-1} 3310,3080(\mathrm{~N}-\mathrm{H}), 1656(\mathrm{C}=\mathrm{O}), 1525(\mathrm{C}=\mathrm{S})$; ${ }^{1} \mathrm{H}$ NMR $\left(\mathrm{d}_{6}\right.$-DMSO) $\delta 11.80\left(\mathrm{~s}, 1 \mathrm{H}, 2^{\prime}-\mathrm{N}-\mathrm{H}\right), 11.60(\mathrm{~s}, 1 \mathrm{H}$, $\mathrm{O}-\mathrm{H}), 11.00\left(\mathrm{t}, 1 \mathrm{H}, J=5.4 \mathrm{~Hz}, 4^{\prime}-\mathrm{N}-\mathrm{H}\right), 7.30-7.20(\mathrm{~m}, 6 \mathrm{H}$, ArH/H-5), 7.10 (d, 1H, J = 7.5 Hz, H-6), 6.90 (d, 1H, $J=$ $7.5 \mathrm{~Hz}, \mathrm{H}-4), 4.80$ (d, $\left.2 \mathrm{H}, J=5.5 \mathrm{~Hz}, \mathrm{H}-5^{\prime}\right), 4.00-3.90$ (q, $\left.2 \mathrm{H}, \mathrm{J}=6.7 \mathrm{~Hz}, \mathrm{O}-\mathrm{CH}_{2}\right), 1.30-1.20\left(\mathrm{t}, 3 \mathrm{H}, J=6.7 \mathrm{~Hz}, \mathrm{CH}_{3}\right)$; ${ }^{13} \mathrm{C}$ NMR $\left(\mathrm{d}_{6}\right.$-DMSO) $\delta 179.5\left(\mathrm{C}-3^{\prime}\right), 164.3\left(\mathrm{C}-1^{\prime}\right), 151.8$ (C-3), 150.5 (C-2), $137.3\left(\mathrm{C}-6^{\prime}\right), 128.5\left(\mathrm{C}-7^{\prime}\right), 127.6\left(\mathrm{C}-8^{\prime}\right)$, $127.3\left({\mathrm{C}-9^{\prime}}^{\prime}\right), 123.0$ (C-5), 118.5 (C-6), 116.5 (C-1), 114.2 (C-4),

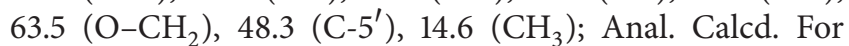
$\mathrm{C}_{17} \mathrm{H}_{18} \mathrm{~N}_{2} \mathrm{O}_{3} \mathrm{~S}$ : C, 61.80; $\mathrm{H}, 5.49 ; \mathrm{N}, 8.48$. Found: C, 61.96; H, $5.61 ; \mathrm{N}, 8.54$. 
$N$-(Benzyl carbamothioyl)-2-hydroxy-5-methoxybenzamide 13h. 6-Methoxy-2-thioxo-2H-benz[e]-1,3-oxazin-4(3H)-one $\mathbf{1 2 h}$ was allowed to react with benzyl amine according to general procedure $\mathrm{C}$. The crude solid was collected and recrystallized from ethyl acetate to give $\mathbf{1 3 h}$ (69\% yield), $\mathrm{mp} 140^{\circ} \mathrm{C} . v_{\max }(\mathrm{KBr}) / \mathrm{cm}^{-1} 3313,3081(\mathrm{~N}-\mathrm{H}), 1667(\mathrm{C}=\mathrm{O})$, $1610(\mathrm{C}=\mathrm{C}), 1516(\mathrm{C}=\mathrm{S}) ;{ }^{1} \mathrm{H}$ NMR (d $\mathrm{d}_{6}$-DMSO) $\delta 12.40(\mathrm{~s}$, $\left.1 \mathrm{H}, 2^{\prime}-\mathrm{N}-\mathrm{H}\right), 11.30(\mathrm{~s}, 1 \mathrm{H}, \mathrm{O}-\mathrm{H}), 11.20(\mathrm{t}, 1 \mathrm{H}, J=5.4 \mathrm{~Hz}$, $\left.4^{\prime}-\mathrm{N}-\mathrm{H}\right), 7.50-7.30$ (m, 8H, ArH/H-3/H-4/H-6), 3.80 (s, $\left.3 \mathrm{H}, \mathrm{O}-\mathrm{CH}_{3}\right) ;{ }^{13} \mathrm{C} \mathrm{NMR}\left(\mathrm{d}_{6}\right.$-DMSO) $\delta 179.9\left(\mathrm{C}-3^{\prime}\right), 165.4$ $\left(\mathrm{C}-1^{\prime}\right), 151.5$ (C-5), $149.0(\mathrm{C}-2), 137.4\left(\mathrm{C}-6^{\prime}\right), 128.5\left(\mathrm{C}-7^{\prime}\right), 127.6$ $\left(\mathrm{C}-8^{\prime}\right), 127.3\left(\mathrm{C}-9^{\prime}\right), 121.8$ (C-3), 117.9 (C-4), 116.4 (C-1), 56.2 $\left(\mathrm{O}-\mathrm{CH}_{3}\right)$, $48.1\left(\mathrm{C}-5^{\prime}\right)$; Anal. Calcd. For $\mathrm{C}_{16} \mathrm{H}_{16} \mathrm{~N}_{2} \mathrm{O}_{3} \mathrm{~S}$ : C, $60.74 ; \mathrm{H}, 5.10$; N, 8.85. Found: C, 60.82; H, 5.18; N, 8.93.

$N$-(Benzyl carbamothioyl)-2-hydroxy-4-methoxybenzamide 13i. 7-Methoxy-2-thioxo-2H-benz[e]-1,3-oxazin-4(3H)-one $12 \mathbf{i}$ was allowed to react with benzyl amine according to general procedure $\mathrm{C}$. The crude solid was collected and recrystallized from ethyl acetate to give $\mathbf{1 3 i}$ ( $87 \%$ yield), $\mathrm{mp}$ $210^{\circ} \mathrm{C} . \nu_{\max }(\mathrm{KBr}) / \mathrm{cm}^{-1} 3313,3081(\mathrm{~N}-\mathrm{H}), 1667(\mathrm{C}=\mathrm{O}), 1610$ $(\mathrm{C}=\mathrm{C}), 1520(\mathrm{C}=\mathrm{S}) ;{ }^{1} \mathrm{H}$ NMR $\left(\mathrm{d}_{6}\right.$-DMSO) $\delta 12.40(\mathrm{~s}, 1 \mathrm{H}$, $\left.2^{\prime}-\mathrm{N}-\mathrm{H}\right), 11.30$ (s, $\left.1 \mathrm{H}, \mathrm{O}-\mathrm{H}\right), 11.20\left(\mathrm{t}, 1 \mathrm{H}, J=5.4 \mathrm{~Hz}, 4^{\prime}-\mathrm{N}-\mathrm{H}\right)$, 7.70 (d, 1H, J = 7.5 Hz, H-6), 7.50-7.30 (m, 5H, ArH), 6.70 (m, $2 \mathrm{H}, \mathrm{H}-3 / \mathrm{H}-5), 3.80$ (s, 3H, O- $\left.\mathrm{CH}_{3}\right) ;{ }^{13} \mathrm{C} \mathrm{NMR}\left(\mathrm{d}_{6}-\mathrm{DMSO}\right)$ $\delta 179.9\left(\mathrm{C}-3^{\prime}\right), 165.4\left({\left.\mathrm{C}-1^{\prime}\right)}^{\prime}\right) 160.5(\mathrm{C}-4), 159.0$ (C-2), 137.4 $\left(\mathrm{C}-6^{\prime}\right), 128.5\left(\mathrm{C}-7^{\prime}\right), 127.6\left(\mathrm{C}-8^{\prime}\right), 127.3\left(\mathrm{C}-9^{\prime}\right), 126.8(\mathrm{C}-6)$, 117.9 (C-5), 116.4 (C-1), 106.0 (C-3), $56.2\left(\mathrm{O}-\mathrm{CH}_{3}\right), 48.1$ (C-5'); Anal. Calcd. For $\mathrm{C}_{16} \mathrm{H}_{16} \mathrm{~N}_{2} \mathrm{O}_{3} \mathrm{~S}$ : C, 60.74; H, 5.10; N, 8.85. Found: C, 60.72; H, 5.20; N, 8.90.

$N$-(Benzyl carbamothioyl)-2-hydroxy-3-methoxybenzamide 13j. 8-Methoxy-2-thioxo-2H-benz[e]-1,3-oxazin-4(3H)-one $12 \mathbf{j}$ was allowed to react with benzyl amine according to general procedure $\mathrm{C}$. The crude solid was collected and recrystallized from toluene to give 13j ( $82 \%$ yield), mp $190-193^{\circ} \mathrm{C} . v_{\max }(\mathrm{KBr}) / \mathrm{cm}^{-1} 3313,3081(\mathrm{~N}-\mathrm{H}), 1667(\mathrm{C}=\mathrm{O})$, $1610(\mathrm{C}=\mathrm{C}), 1518(\mathrm{C}=\mathrm{S}) ;{ }^{1} \mathrm{H}$ NMR $\left(\mathrm{d}_{6}\right.$-DMSO) $\delta 12.40(\mathrm{~s}, 1 \mathrm{H}$, $\left.2^{\prime} \mathrm{N}-\mathrm{H}\right), 11.30(\mathrm{~s}, 1 \mathrm{H}, \mathrm{O}-\mathrm{H}), 11.20\left(\mathrm{t}, 1 \mathrm{H}, J=5.4 \mathrm{~Hz}, 4^{\prime}-\mathrm{N}-\mathrm{H}\right)$, 7.50-7.20 (m, 8H, ArH/H-4/H-5/H-6), 3.80 (s, 3H, O- $\mathrm{CH}_{3}$ ); ${ }^{13} \mathrm{C}$ NMR (d $\mathrm{d}_{6}$-DMSO) $\delta 179.9\left(\mathrm{C}-3^{\prime}\right), 165.4\left(\mathrm{C}-1^{\prime}\right), 149.5$ (C-3), 148.0 (C-2), $137.4\left(\mathrm{C}-6^{\prime}\right), 128.5\left(\mathrm{C}-7^{\prime}\right), 127.6\left(\mathrm{C}-8^{\prime}\right)$, $127.3\left({\mathrm{C}-9^{\prime}}^{\prime}\right), 121.8$ (C-6), 117.9 (C-5), 116.4 (C-1), 116.0 (C-4), $56.2\left(\mathrm{O}-\mathrm{CH}_{3}\right), 48.1\left(\mathrm{C}-5^{\prime}\right)$; Anal. Calcd. For $\mathrm{C}_{16} \mathrm{H}_{16} \mathrm{~N}_{2} \mathrm{O}_{3} \mathrm{~S}$ : C, 60.74; H, 5.10; N, 8.85. Found: C, 60.82; H, 5.18; N, 8.93.

$N$-(Benzyl carbamothioyl)-2-hydroxy-3,5-diiodobenzamide 13k. 6,8-diiodo-2-thioxo-2H-benz[e]-1,3-oxazin-4(3H)-one 12k was allowed to react with benzylamine according to general procedure $C$. The solid was collected and recrystallized from toluene to give $13 \mathbf{k}$ (75\% yield), $\mathrm{mp}$ $173-175^{\circ}$ C. $v_{\max }(\mathrm{KBr}) / \mathrm{cm}^{-1} 3264,3025(\mathrm{~N}-\mathrm{H}), 1633(\mathrm{C}=\mathrm{O})$, $1576(\mathrm{C}=\mathrm{C}), 1545(\mathrm{C}=\mathrm{S}) ;{ }^{1} \mathrm{H}$ NMR (d $\left.-\mathrm{DMSO}\right) \delta 11.90(\mathrm{~s}, 1 \mathrm{H}$, $\left.2^{\prime}-\mathrm{N}-\mathrm{H}\right), 10.90\left(\mathrm{t}, 1 \mathrm{H}, J=5.4 \mathrm{~Hz}, 4^{\prime}-\mathrm{N}-\mathrm{H}\right), 8.20(\mathrm{~d}, 1 \mathrm{H}, J=$ $2.2 \mathrm{~Hz}, \mathrm{H}-6), 8.00$ (d, $1 \mathrm{H}, J=2.2 \mathrm{~Hz}, \mathrm{H}-4), 7.40-7.30$ (m, 5H, ArH), $4.90\left(\mathrm{~d}, 2 \mathrm{H}, J=5.5 \mathrm{~Hz}, \mathrm{H}-5^{\prime}\right),{ }^{13} \mathrm{C} \mathrm{NMR}\left(\mathrm{d}_{6}\right.$-DMSO) $\delta 179.8\left(\mathrm{C}-3^{\prime}\right), 165.6\left(\mathrm{C}-1^{\prime}\right), 157.0$ (C-2), 149.7 (C-4), 137.9 $\left(\mathrm{C}-6^{\prime}\right), 137.3$ (C-6), $128.5\left(\mathrm{C}-7^{\prime}\right), 127.7\left(\mathrm{C}-8^{\prime}\right), 127.3\left(\mathrm{C}-9^{\prime}\right)$, 121.1 (C-1), 91.75 (C-5), 81.9 (C-3), 48.2 (C-5'); Anal. Calcd.
For $\mathrm{C}_{15} \mathrm{H}_{12} \mathrm{I}_{2} \mathrm{~N}_{2} \mathrm{O}_{2} \mathrm{~S}$ : C, 33.48; H, 2.25; N, 5.21. Found: C, $33.43 ; \mathrm{H}, 2.66$; N, 5.78 .

$N$-(Benzyl carbamothioyl)-2,4-dihydroxybenzamide 131. 7-Hydroxy-2-thioxo-2H-benz[e]-1,3-oxazin-4(3H)-one $\mathbf{1 2 1}$ was allowed to react with benzylamine according to general procedure $\mathrm{C}$. The solid was collected and recrystallized from toluene to give $131(87 \%$ yield $), \mathrm{mp} 190^{\circ} \mathrm{C} . v_{\max }(\mathrm{KBr}) / \mathrm{cm}^{-1}$ 3200-2700 (O-H), 3118, $3033(\mathrm{~N}-\mathrm{H}), 1665(\mathrm{C}=\mathrm{O}), 1626$ $(\mathrm{C}=\mathrm{C}), 1554(\mathrm{C}=\mathrm{S}) ;{ }^{1} \mathrm{H}$ NMR ( $\mathrm{d}_{6}$-DMSO) $\delta 12.10$ (bs, $1 \mathrm{H}$, $\mathrm{O}-\mathrm{H}), 11.30$ (s, 1H, N-H), 11.20 (t, 1H, J = 5.4 Hz, N-H), 10.50 $(\mathrm{O}-\mathrm{H}), 7.80$ (d, 1H, J = 7.6 Hz, H-6), 7.30 (m, 5H, ArH), 6.40 (m, 2H, H-3/H-5), 4.80 (d, 2H, $\left.J=5.7 \mathrm{~Hz}, \mathrm{H}-5^{\prime}\right) ;{ }^{13} \mathrm{C} \mathrm{NMR}$ $\left(\mathrm{d}_{6}\right.$-DMSO) $\delta 180.0\left(\mathrm{C}-3^{\prime}\right), 164.7\left(\mathrm{C}-1^{\prime}\right), 163.9(\mathrm{C}-4), 158.5$ (C-2), $137.5\left(\mathrm{C}-6^{\prime}\right), 133.3(\mathrm{C}-6), 128.7\left(\mathrm{C}-7^{\prime}\right), 127.7\left(\mathrm{C}-8^{\prime}\right), 127.5$ (C-9'), 109.2 (C-5), 107.9 (C-1), 102.9 (C-3), 48.2 (C-5'); Anal. Calcd. For $\mathrm{C}_{15} \mathrm{H}_{14} \mathrm{~N}_{2} \mathrm{O}_{3} \mathrm{~S}$ : C, 59.59; H, 4,67; N, 9.27. Found: C, 59.88; H, 4.68; N, 9.59.

$N$-(Benzyl carbamothioyl)-2,4-dihydroxy-3-methylbenza-

mide 13m. 7-Hydroxy-8-methyl-2-thioxo-2H-benz[e]-1,3oxazin-4(3H)-one $\mathbf{1 2 m}$ was allowed to react with benzylamine according to general procedure $\mathrm{C}$. The solid was collected and recrystallized from ethanol to give 13m (78\% yield), mp 193-195 C. $\nu_{\max }(\mathrm{KBr}) 3381,3225$ (O$\mathrm{H}), 3020-2800(\mathrm{~N}-\mathrm{H}), 1639(\mathrm{C}=\mathrm{O}), 1613(\mathrm{C}=\mathrm{S}) ;{ }^{1} \mathrm{H}$ NMR $\left(\mathrm{d}_{6}-\mathrm{DMSO}\right) \delta 11.60(\mathrm{bs}, 1 \mathrm{H}, 2-\mathrm{OH}), 11.10(\mathrm{t}, 1 \mathrm{H}, J=5.6 \mathrm{~Hz}$, $\left.4^{\prime}-\mathrm{NH}\right), 10.40$ (bs, $\left.1 \mathrm{H}, 2^{\prime}-\mathrm{NH}\right), 7.70\left(\mathrm{~d}, 1 \mathrm{H}, J_{\mathrm{H} 6 \mathrm{H} 5}=8.8 \mathrm{~Hz}\right.$; H-6), 7.40-7.30 (m, 6H/H-7 $\left./ \mathrm{H}-8^{\prime} / \mathrm{H}-9^{\prime} / 4-\mathrm{OH}\right), 6.50(\mathrm{~d}, 1 \mathrm{H}$, $\left.J_{\mathrm{H} 5, \mathrm{H} 6}=8.8 \mathrm{~Hz} ; \mathrm{H}-5\right), 4.90\left(\mathrm{~d}, 2 \mathrm{H}, J=5.6 \mathrm{~Hz}, \mathrm{H}-5^{\prime}\right), 2.00$ $\left(\mathrm{s}, 3 \mathrm{H}, 3-\mathrm{CH}_{3}\right) ;{ }^{13} \mathrm{C}$ NMR $\left(\mathrm{d}_{6}\right.$-DMSO) $\delta 179.9\left(\mathrm{C}-3^{\prime}\right), 166.1$ $\left(\mathrm{C}-1^{\prime}\right), 161.5(\mathrm{C}-4), 157.2$ (C-2), $137.3\left(\mathrm{C}-6^{\prime}\right), 129.1\left(\mathrm{C}-7^{\prime}\right), 128.4$ $\left(\mathrm{C}-8^{\prime}\right), 127.5\left(\mathrm{C}-9^{\prime}\right), 127.2$ (C-6, C-3), 111.8 (C-1), 108.3 (C-5), $48.1\left(\mathrm{C}-5^{\prime}\right), 8.6\left(3-\mathrm{CH}_{3}\right)$. Anal. Calcd. For $\mathrm{C}_{16} \mathrm{H}_{16} \mathrm{~N}_{2} \mathrm{O}_{3} \mathrm{~S} \mathrm{C}$, 60.74; H, 5.10; N, 8.85. Found: C, 60.60; H, 5.08; N, 8.80; \%.

N-(Benzyl carbamothioyl)-2,3-dihydroxybenzamide $\mathbf{1 3 n}$. 8-Hydroxy-2-thioxo-2H-benz[e]-1,3-oxazin-4(3H)-one $\mathbf{1 2 n}$ was allowed to react with benzyl amine according to general procedure $\mathrm{C}$. The crude solid was collected and recrystallized from ethanol to give $13 n$ ( $72 \%$ yield), $m p 172^{\circ} \mathrm{C} . v_{\max }$ $(\mathrm{KBr}) / \mathrm{cm}^{-1}$ 3411, 2942 br $(\mathrm{O}-\mathrm{H}), 3118,3033(\mathrm{~N}-\mathrm{H}), 1661$ $(\mathrm{C}=\mathrm{O}), 1626(\mathrm{C}=\mathrm{C}), 1553(\mathrm{C}=\mathrm{S}) ;{ }^{1} \mathrm{H}$ NMR ( $\mathrm{d}_{6}$-DMSO) $\delta$ $11.61\left(\mathrm{~s}, 1 \mathrm{H}, 2^{\prime}-\mathrm{N}-\mathrm{H}\right), 11.22\left(\mathrm{t}, 1 \mathrm{H}, J=5.6 \mathrm{~Hz}, 4^{\prime}-\mathrm{N}-\mathrm{H}\right), 10.53$ (O-H), 7.30 (m, 7H, ArH/H-6), 7.00 (d, 1H, J = 7.6 Hz, H-4), $6.70(\mathrm{t}, 1 \mathrm{H}, J=7.9 \mathrm{~Hz}, \mathrm{H}-5), 4.80\left(\mathrm{~d}, 2 \mathrm{H}, J=5.7 \mathrm{~Hz}, \mathrm{H}-5^{\prime}\right)$; ${ }^{13} \mathrm{C}$ NMR $\left(\mathrm{d}_{6}\right.$-DMSO) $\delta 179.7\left(\mathrm{C}-3^{\prime}\right), 165.0\left(\mathrm{C}-1^{\prime}\right), 146.6$ (C-2), 146.3 (C-3), $137.3\left(\mathrm{C}-6^{\prime}\right), 128.5\left(\mathrm{C}-7^{\prime}\right), 127.6$ (C-8' $), 127.3$ (C-9'), 120.5 (C-5), 119.4 (C-4), 119.2 (C-5), 116.8 (C-1), 48.2 $\left(\mathrm{C}-5^{\prime}\right)$; Anal. Calcd. For $\mathrm{C}_{15} \mathrm{H}_{14} \mathrm{~N}_{2} \mathrm{O}_{3} \mathrm{~S}$ : C, 59.59; H, 4.67; N, 9.27. Found: C, 60.08; H, 5.06; N, 9.59.

4-Amino-N-(benzyl carbamothioyl)-2-hydroxybenzamide $\mathbf{1 3 o .}$ 7-Amino-2-thioxo-2H-benz[e][1,3] oxazin-4(3H)-one $\mathbf{1 0 b}$ was allowed to react with benzylamine following general procedure $\mathrm{C}$. The resulting solid was collected and recrystallised from methanol/water to give $130(0.35 \mathrm{~g}, 78 \%)$ as off white solid, mp $290-293^{\circ} \mathrm{C}$ decomp. $v_{\max }(\mathrm{KBr}) / \mathrm{cm}^{-1}$ 3500-3200 (OH), 3442, $3332(\mathrm{NH}), 1750,1677$ (C=O), 1388 
(C=S);. ${ }^{1}$ HNMR (200 MHz, $300 \mathrm{~K}, \mathrm{~d}_{6}$-DMSO) $\delta 11.54(\mathrm{~s}$, $1 \mathrm{H}, 8-\mathrm{NH}$ exchangeable with $\left.\mathrm{D}_{2} \mathrm{O}\right), 11.33-11.28(\mathrm{bm}, 2 \mathrm{H}$, $10-\mathrm{NH}, 2-\mathrm{OH}$ exchangeable with $\left.\mathrm{D}_{2} \mathrm{O}\right), 7.60\left(\mathrm{~d}, 1 \mathrm{H}, J_{\mathrm{H} 6, \mathrm{H} 5}\right.$ $=8.6 \mathrm{~Hz}, \mathrm{H}-6), 7.33-7.29(\mathrm{~m}, 7 \mathrm{H}, \mathrm{Ar}, \mathrm{H}-11, \mathrm{H}-12, \mathrm{H}-13$ and 4- $\mathrm{NH}_{2}$ exchangeable with $\left.\mathrm{D}_{2} \mathrm{O}\right), 6.21\left(\mathrm{dd}, 1 \mathrm{H}, \mathrm{J}_{\mathrm{H} 5, \mathrm{H} 6 \& \mathrm{H} 5 \mathrm{H} 3}=\right.$ $\left.8.6 \mathrm{~Hz}, J_{\mathrm{H} 5, \mathrm{H} 3}=1.6 \mathrm{~Hz}, \mathrm{H}-3\right),\left(\mathrm{d}, 1 \mathrm{H}, J_{\mathrm{H} 3, \mathrm{H} 5}=1.6 \mathrm{~Hz}, \mathrm{H}-3\right)$, $4.84\left(\mathrm{~d}, 2 \mathrm{H}, J_{\mathrm{H} 11, \mathrm{H} 10}=5.7 \mathrm{~Hz}, \mathrm{H}-11\right) ;{ }^{13} \mathrm{C} \mathrm{NMR}(50 \mathrm{MHz}$, $300 \mathrm{~K}, \mathrm{~d}_{6}$-DMSO) $\delta 180.3$ (C-9), 165.2 (C-7), 158.6 (C-2), 155.1 (C-4), 137.7 (C-12), 133.2 (C-6), 128.9 (C-14), 127.8, 127.7 (C-13, C-15), 108.2 (C-5), 104.3 (C-1), 99.7 (C-3), 48.4 (C-11); Anal. Calcd. For $\mathrm{C}_{15} \mathrm{H}_{15} \mathrm{~N}_{3} \mathrm{O}_{2} \mathrm{~S}$ : C, 59.78; H, 5.02; N, 13.94 . Found: C, 59.55; H, 5.08; N, 13.72.

4-Acetamido-N-(benzyl carbamothioyl)-2-hydroxybenzamide 13p. $N$-(4-Oxo-2-thioxo-3, 4-dihydro-2H-benz [e][1,3] oxazin-7-yl) acetamide 10a was allowed to react with benzylamine following general procedure $\mathrm{C}$. The resulting solid was collected and recrystallised from ethanol to give $\mathbf{1 3 p}$ $(0.27 \mathrm{~g}, 47 \%)$ as off white crystals. $\mathrm{mp} 263-266^{\circ} \mathrm{C} . v_{\max }$ $(\mathrm{KBr}) / \mathrm{cm}^{-1} 3500-3200(\mathrm{OH}), 3292,3113,(\mathrm{NH}), 1656(\mathrm{C}=\mathrm{O})$, $1374(\mathrm{C}=\mathrm{S}) ;{ }^{1} \mathrm{HNMR}\left(200 \mathrm{MHz}, 300 \mathrm{~K}, \mathrm{~d}_{6}\right.$-DMSO) $\delta 12.09$ (s, $1 \mathrm{H}, 16-\mathrm{NH}), 11.40(\mathrm{~s}, 1 \mathrm{H}, 8-\mathrm{NH}), 11.18\left(\mathrm{t}, 1 \mathrm{H}, J_{\mathrm{H} 10, \mathrm{H} 11}=4.6 \mathrm{~Hz}\right.$, $10-\mathrm{NH}), 10.26(\mathrm{~s}, 1 \mathrm{H}, 2-\mathrm{OH}), 7.84\left(\mathrm{~d}, 1 \mathrm{H}, J_{\mathrm{H} 6, \mathrm{H} 5}=7.8 \mathrm{~Hz} \mathrm{H}-6\right)$, 7.64 (s, 1H, H-3), 7.37-7.30 (m, 5H, Ar, H-13, H-14, H-15), $7.02\left(\mathrm{~d}, 1 \mathrm{H}, J_{\mathrm{H} 5, \mathrm{H} 6}=7.8 \mathrm{~Hz}, \mathrm{H}-5\right), 4.85\left(\mathrm{~d}, 2 \mathrm{H}, J_{\mathrm{H} 11, \mathrm{H} 10}=\right.$ $4.8 \mathrm{~Hz}, \mathrm{H}-11), 2.07$ (s, $\left.3 \mathrm{H}, \mathrm{CH}_{3}\right) ;{ }^{13} \mathrm{C}$ NMR $(50 \mathrm{MHz}, 300 \mathrm{~K}$, $\mathrm{d}_{6}$-DMSO) $\delta 179.7$ (C-9), 169.1 (C-7), 164.2 (C-17), 157.4 (C-2), 145.3 (C-4), 137.3 (C-12), 131.9 (C-6), 128.5, 127.6, 127.3 (C-13, C-14, C-15), 111.0, 110.8 (C-1, C-5), 105.9 (C-3), 48.1 (C-11), 24.2 (C-18); Anal. Calcd. For $\mathrm{C}_{17} \mathrm{H}_{17} \mathrm{~N}_{3} \mathrm{O}_{3} \mathrm{~S}$ : C, 59.46; H, 4.97; N, 12.24. Found: C, 59.20; H, 5.07; N, 12.02 .

\section{$\mathrm{N}$-(Benzyl carbamothioyl)-4-((3-ethoxy-2-hydroxybenzyl)} amino)-2-hydroxybenzamide 13q. 3-Ethoxy-2-hydroxy-1,3benzoxazine 11c was allowed to react with benzylamine according to the general procedure $\mathrm{C}$. The resulting solid was collected and recrystallised from acetonitrile to give 13q $(0.59 \mathrm{~g}, 77 \%)$ as yellow crystals, $\mathrm{mp} 201-204^{\circ} \mathrm{C} . v_{\max }$ $(\mathrm{KBr}) / \mathrm{cm}^{-1}$ 3500-3200 (OH), 3496, 3395, $3256(\mathrm{NH}), 1686$, $1646(\mathrm{C}=\mathrm{O}), 1342(\mathrm{C}=\mathrm{S}) ;{ }^{1} \mathrm{HNMR}\left(200 \mathrm{MHz}, 300 \mathrm{~K}, \mathrm{~d}_{6^{-}}\right.$ DMSO) $\delta 11.26(8-\mathrm{NH}), 8.33(\mathrm{~m}, 1 \mathrm{H}, 2-\mathrm{OH}), 7.63\left(\mathrm{~d}, 1 \mathrm{H}, J_{\mathrm{H} 6, \mathrm{H} 5}\right.$ $=9.0 \mathrm{~Hz}, \mathrm{H}-6), 7.66-7.28$ (m, 5H, Ar H-13, H-14, H-15), 7.1 (t, $\left.1 \mathrm{H}, J_{\mathrm{H} 16, \mathrm{H} 17}=5.1 \mathrm{~Hz}, \mathrm{H}-16\right), 6.92-6.66(\mathrm{~m}, 5 \mathrm{H}, \mathrm{H}-21, \mathrm{H}-22$, $\mathrm{H}-25,10-\mathrm{NH}$ and 19-OH exchangeable with $\mathrm{D}_{2} \mathrm{O}$ ), 6.30 (dd, $\left.1 \mathrm{H}, J_{\mathrm{H} 5, \mathrm{H} 6 \& \mathrm{H} 5, \mathrm{H} 3}=9.0 \mathrm{~Hz}, J_{\mathrm{H} 5, \mathrm{H} 3}=1.6 \mathrm{~Hz}, \mathrm{H}-5\right), 6.14(\mathrm{~d}, 1 \mathrm{H}$, $\left.J_{\mathrm{H} 3, \mathrm{H} 5}=1.6 \mathrm{~Hz}, \mathrm{H}-3\right), 4.85\left(\mathrm{~d}, 2 \mathrm{H}, J_{\mathrm{H} 11, \mathrm{H} 10}=5.1 \mathrm{~Hz}, \mathrm{H}-11\right), 4.25$ $\left(\mathrm{d}, 2 \mathrm{H}, J_{\mathrm{H} 17, \mathrm{H} 16}=5.3 \mathrm{~Hz}, \mathrm{H}-17\right), 4.08-4.01\left(\mathrm{~m}, 3 \mathrm{H}, J_{\mathrm{H} 24, \mathrm{H} 25}=\right.$ $7.0 \mathrm{~Hz}, \mathrm{H}-24$ and $16-\mathrm{NH}), 1.45$ (t, $\left.3 \mathrm{H}, J_{\mathrm{H} 25, \mathrm{H} 24}=7.0 \mathrm{~Hz}, \mathrm{H}-25\right)$; ${ }^{13} \mathrm{C}$ NMR $\left(50 \mathrm{MHz}, 340 \mathrm{~K}, \mathrm{~d}_{6}\right.$-DMSO) $\delta 180.1$ (C-9), 164.8 (C-7), 158.2 (C-2), 154.7 (C-4), 146.3, 144.1 (C-20, C-19), 137.2 (C-12), 132.1 (C-6), 128.2, 127.3, 127.0 (C-14, C-13, C-15), 125.1 (C-18), 119.9, 118.5 (C-21, C-23), 111.8 (C-22), 106.1, 103.6 (C-1, C-5), 97.2 (C-3), 64.1 (C-24), 47.9 (C-17), 40.8 (C-11), 14.4 (C25); Anal. Calcd. For $\mathrm{C}_{24} \mathrm{H}_{25} \mathrm{~N}_{3} \mathrm{O}_{4} \mathrm{~S} \cdot \mathrm{H}_{2} \mathrm{O}: \mathrm{C}, 61.39 ; \mathrm{H}, 5.80 ; \mathrm{N}$, 8.95. Found: C, 61.59; H, 5.57; N, 9.38.

4.1.9. N1,N3-Bis(benzyl carbamothioyl)-4,6-dihydroxy-lisophthalamide 20a. In slight modification to the general procedure C, 2, 8-dithioxo-2, 3, 7, 8-tetrahydrobenzo[1,2-e:
5,4- $\left.e^{\prime}\right]$ bis([1,3] oxazine)-4,6-dione $\mathbf{1 8 a}(1 \mathrm{mmol}, 0.28 \mathrm{~g})$ was allowed to react with benzylamine $(3 \mathrm{mmol} .0 .32 \mathrm{~g})$ and sodium hydrogen carbonate solution ( $1 \mathrm{~g}$ in $12 \mathrm{~mL}$ methanol and $2.4 \mathrm{~mL}$ water) for 16 hour. The resulting solid was collected and recrystallised from ethanol to give 20a $(0.31 \mathrm{~g}$, $63 \%)$ as off white crystals.mp $276-279^{\circ} \mathrm{C}$ decomp. $v_{\max }$ $(\mathrm{KBr}) / \mathrm{cm}^{-1}$ 3313, (NH), $1672(\mathrm{C}=\mathrm{O}), 1328(\mathrm{C}=\mathrm{S}),{ }^{1} \mathrm{HNMR}$ $\left(200 \mathrm{MHz}, 340 \mathrm{~K}, \mathrm{~d}_{6}\right.$-DMSO) $\delta 11.25$ (bs, $2 \mathrm{H}, 2 \times \mathrm{NH}$ ), 11.06 $\left(\mathrm{t}, 2 \mathrm{H}, J_{\mathrm{H} 10, \mathrm{H} 11}=5.7 \mathrm{~Hz}, \mathrm{H}-10,18\right), 8.60(\mathrm{~s}, 1 \mathrm{H}, \mathrm{H}-6), 7.38_{-}$ $7.29\left(10 \mathrm{H}, 2\right.$ x Ar), $6.63(\mathrm{~s}, 1 \mathrm{H}, \mathrm{H}-3), 4.87\left(\mathrm{~d}, 4 \mathrm{H}, J_{\mathrm{H} 11, \mathrm{H} 10}\right.$ $=5.7 \mathrm{~Hz}, \mathrm{H}-11,20), 3.3(\mathrm{OH}$ under the water envelope $) ;{ }^{13} \mathrm{C}$ NMR (50 MHz, $340 \mathrm{~K}, \mathrm{~d}_{6}$-DMSO) $\delta 179.5$ (C-9,17), 163.3 (C7,15), 161.5 (C-2,4), 137.0, 136.6 (C-11, 20 and C-6), 128.2, 127.3, 127.0 (C-13, 22, C-12, 21 and C-14, 25), 110.3 (C-1,15), 103.7 (C3), 48.0 (C-11,19); Anal. Calcd. For $\mathrm{C}_{24} \mathrm{H}_{22} \mathrm{~N}_{4} \mathrm{O}_{4} \mathrm{~S}_{2}$ : C, 58.28; H, 4.48; N, 11.33. Found: C, 58.37; H, 4.67; N, 11.22.

4.1.10. N1,N3-Bis(benzyl carbamothioyl)-4,6-dihydroxy-5-methylisophthalamide 20c. In slight modification to general procedure C, 10-methyl-2,8-bis(methylthio)benzo[1,2-e: $\left.5,4-e^{\prime}\right]$ bis([1,3] oxazine)-4,6-dione $18 \mathrm{c}(1 \mathrm{mmol}, 0.32 \mathrm{~g})$ was allowed to react with benzylamine ( $3 \mathrm{mmol} .0 .32 \mathrm{~g}$ ), Sodium hydrogen carbonate solution $(1 \mathrm{~g}$ in $12 \mathrm{~mL}$ methanol and $2.4 \mathrm{~mL}$ water) for $16 \mathrm{~h}$. The resulting solid was collected and recrystallised from ethanol to give $20 \mathrm{c}(0.25 \mathrm{~g}, 49 \%)$ as off white crystals. $\mathrm{mp} 227-229^{\circ} \mathrm{C}$ decomp. $\nu_{\max }(\mathrm{KBr}) / \mathrm{cm}^{-1}$ 3500-3200 (OH), 3414, $3257(\mathrm{NH}), 1651(\mathrm{C}=\mathrm{O}), 1321(\mathrm{C}=\mathrm{S})$; ${ }^{1} \mathrm{HNMR}\left(200 \mathrm{MHz}, 340 \mathrm{~K}, \mathrm{~d}_{6}\right.$-DMSO) $\delta 11.51$ (bs, $2 \mathrm{H}, 2$ $\mathrm{x} \mathrm{NH}), 10.96\left(\mathrm{~s}, 2 \mathrm{H}, J_{\mathrm{H} 10-\mathrm{H} 11}=5.7 \mathrm{~Hz}, \mathrm{H}-10,19\right), 8.48(\mathrm{~s}$, $1 \mathrm{H}, \mathrm{H}-6), 7.39-7.28(\mathrm{~m}, 10 \mathrm{H}, 2 \times \mathrm{Ar}), 4.90\left(\mathrm{~d}, 2 \mathrm{H}, J_{\mathrm{H} 9, \mathrm{H} 8}=\right.$ $5.7 \mathrm{~Hz}, \mathrm{H}-11,20), 2.10$ (s, 3H, H-3), $3.3(\mathrm{OH}$ under the water envelope); ${ }^{13} \mathrm{C}$ NMR $\left(50 \mathrm{MHz}, 340 \mathrm{~K}, \mathrm{~d}_{6}\right.$-DMSO) $\delta 179.6$ (C-9, 18), 166.3 (C-7,16), 161.3 (C-2, 4), 136.9 (C-12, 21), 131.2 (C-4), 128.1 (C-14, 23), 127.3, 127.0 (C-13, 22 and C-15, 24), 113.2 (C-1,5), 108.9 (C-3), 48.1 (C-11, 20), 8.4 (C-1, 5); Anal. Calcd. For $\mathrm{C}_{25} \mathrm{H}_{25} \mathrm{~N}_{4} \mathrm{O}_{4} \mathrm{~S} \cdot \mathrm{H}_{2} \mathrm{O}$ : C, 57.02; H, 4.98; N, 10.64 . Found: C, 57.32; H, 4.48; N, 10.85 .

4.1.11. N1,N4-Bis(benzyl carbamothioyl)-2,3-dihydroxyterephthalamide 21. In slight modification to the general procedure C, 2,9-dithioxo-2,3,8,9-tetrahydrobenzo[1,2-e:4,3- $\left.e^{\prime}\right]$ bis([1,3] oxazine)-4,7-dione 19 ( $1 \mathrm{mmol}, 0.28 \mathrm{~g})$ was allowed to react with benzylamine $(3 \mathrm{mmol} .0 .32 \mathrm{~g})$, sodium hydrogen carbonate solution ( $1 \mathrm{~g}$ in $12 \mathrm{~mL}$ methanol and $2.4 \mathrm{~mL}$ water) for 16 hour. The resulting solid was collected and recrystallised using ethanol to give $21(0.31 \mathrm{~g}, 63 \%)$ as off white crystals mp $195-198^{\circ} \mathrm{C}$. $v_{\max }(\mathrm{KBr}) / \mathrm{cm}^{-1} 3500-3200(\mathrm{OH})$, 3401, $3248(\mathrm{NH}), 1671,1649$ (C=O), 1338 (C=S); ${ }^{1} \mathrm{HNMR}$ (200 MHz, $300 \mathrm{~K}, \mathrm{~d}_{6}$-DMSO) $\delta 11.88$ (bs, $2 \mathrm{x} \mathrm{NH}, \mathrm{H}-8,17$ ), $11.07\left(\mathrm{t}, 1 \mathrm{H}, J_{\mathrm{H} 10, \mathrm{H} 11}=5.9 \mathrm{~Hz}, \mathrm{H}-10,19\right), 8.56$ (bs, 2H, 2,3-OH), 7.39-7.28 (m, 12H, $2 \times$ Ar and $2 \times \mathrm{CH}, \mathrm{H}-13, \mathrm{H}-14, \mathrm{H}-15$ and $\mathrm{H}-5,6), 4.88\left(\mathrm{~d}, 4 \mathrm{H}, J_{\mathrm{H} 11, \mathrm{H} 10}=5.9 \mathrm{~Hz}, \mathrm{H}-11,20\right) ;{ }^{13} \mathrm{C} \mathrm{NMR}$ (50 MHz, $340 \mathrm{~K}, \mathrm{~d}_{6}$-DMSO) $\delta 179.6$ (C-9,18), 164.9 (C-7,16), 147.9 (C-2,3), 136.9 (C-12, 21), 128.2 (C-14,23), 127.3 (C-13,22), 127.0 (C-15,24), 120.9 (C-1,4), 119.2 (C-5,6); Anal. Calcd. For $\mathrm{C}_{24} \mathrm{H}_{22} \mathrm{~N}_{4} \mathrm{O}_{4} \mathrm{~S}_{2} \cdot \mathrm{H}_{2} \mathrm{O}: \mathrm{C}, 56.23 ; \mathrm{H}, 4.72 ; \mathrm{N}, 11.33$. Found: C, $55.79 ; \mathrm{H}, 4.78 ; \mathrm{N}, 10.93$. 
4.1.12. Synthesis N-(2-(Methylthio)-4-oxo-4H-benz[e][1,3]oxazin-7-yl)acetamide 14h. N-(4-Oxo-2-thioxo-3,4-dihydro$2 H$-benz $[e][1,3]$ oxazin-7-yl)acetamide 10a (0.59 g, $2.5 \mathrm{mmol})$ was allowed to react with methyl iodide following the previously reported [35]. The resulting beige solid $\mathbf{1 4 h}(0.61 \mathrm{~g}$, 97\%) is collected and used without further purification but can be crystallised from ethanol, mp $268-269^{\circ} \mathrm{C} \nu_{\max }$ $(\mathrm{KBr}) / \mathrm{cm}^{-1}$ 3278, 3142, $3110(\mathrm{NH}), 3062(\mathrm{CH} \mathrm{Ar}), 2929(\mathrm{CH}$ Aliphatic), 1760, 1709, $1671(\mathrm{C}=\mathrm{O}), 1615(\mathrm{C}=\mathrm{N}), 1554(\mathrm{C}=\mathrm{C})$; ${ }^{1} \mathrm{HNMR}\left(200 \mathrm{MHz}, 300 \mathrm{~K} \mathrm{~d}_{6}\right.$-DMSO) $\delta 10.60$ (s, 1H, 9-NH), 7.88 (b, 1H, H-8), 7.87 (d, 1H, $\left.J_{\mathrm{H} 5, \mathrm{H} 6}=8.6 \mathrm{~Hz}, \mathrm{H}-5\right), 7.45$ $\left(\mathrm{d}, 1 \mathrm{H}, J_{\mathrm{H} 6, \mathrm{H} 5}=8.6 \mathrm{~Hz}, \mathrm{H}-6\right), 2.58\left(\mathrm{~s}, 3 \mathrm{H}, 11-\mathrm{CH}_{3}\right), 2.12(\mathrm{~s}$, $3 \mathrm{H}, 3^{\prime}-\mathrm{CH}_{3}$ ); ${ }^{13} \mathrm{C}$ NMR (50 MHz, $300 \mathrm{k}, \mathrm{d}_{6}$-DMSO) $\delta 172.8$ (C-2), 169.6 (C-10), 162.1 (C-4), 155.8 (C-8a), 145.2 (C-7), 128.0 (C-5), 117.5 (C-6), 112.1 (C-4a), 104.4 (C-8); Anal. Calcd. For $\mathrm{C}_{15} \mathrm{H}_{12} \mathrm{~N}_{2} \mathrm{O}_{2} \mathrm{~S}$ : C, 59.99; $\mathrm{H}, 4.03 ; \mathrm{N}, 9.33$. Found: C, 59.83; $\mathrm{H}, 4.14 ; \mathrm{N}, 9.45$.

\subsubsection{Synthesis of 2-Benzyl amino-1,3-benzoxazines $\mathbf{1 5 a} \boldsymbol{h}$}

General Procedure D. The appropriate 2-methylthio-1,3benzoxazine 14a-h $(2.5 \mathrm{mmol})$ was suspended in dry 1,4dioxane $(10 \mathrm{~mL})$ in a $50 \mathrm{~mL}$ round-bottomed flask. Benzyl amine $(12.5 \mathrm{mmol})$ was then added dropwise, directly from the pipette, with stirring, and then the reaction mixture was heated to reflux for 4 hours. At the completion of the reaction, the reaction mixture was evaporated to dryness under reduced pressure and triturated with minimal diethyl ether. The resulting solid product 14 was collected by vacuum filtration and recrystallized from an appropriate solvent.

General Procedure E. N-(Benzyl carbamothioyl)-substituted2-hydroxy-benzamides $13 \mathbf{a}, \mathbf{b}, \mathbf{e}, \mathbf{f}$, and $\mathbf{g}(0.5 \mathrm{mmol})$ were suspended in acetic acid $(3 \mathrm{~mL})$ in a $25 \mathrm{~mL}$ round-bottomed flask. The reaction mixture was heated to reflux for 2 hours then; the acetic acid was evaporated off under reduced pressure. The oily reaction mixture was triturated with minimal diethyl ether and the resulting solid products $15 \mathbf{a}, \mathbf{b}, \mathbf{e}, \mathbf{f}$, and g were collected by vacuum filtration and recrystallized from an appropriate solvent.

Products $\mathbf{1 5 a}, \mathbf{b}, \mathbf{e}, \mathbf{f}$, and $\mathbf{g}$ prepared in this procedure gave identical mp, IR, ${ }^{1} \mathrm{H}$ NMR and ${ }^{13} \mathrm{C} \mathrm{NMR}$ to the analogues prepared from compound $\mathbf{1 4}$ with comparable yields (Scheme 3).

2-(Benzyl amino)-4H-benz[e]-1,3-oxazin-4-one 15a. 2-(Methylthio)-4H-benz[e]-1,3-oxazin-4-one 14a was allowed to react with benzyl amine according to general procedure D. The crude solid was collected and recrystallized from ethanol to give $15 \mathbf{a}(75 \%$ yield $), \operatorname{mp} 210^{\circ} \mathrm{C} . \nu_{\max }(\mathrm{KBr}) / \mathrm{cm}^{-1} 3065,2872$ $(\mathrm{N}-\mathrm{H}), 1681(\mathrm{C}=\mathrm{O}), 1635(\mathrm{C}=\mathrm{C}), 1460(\mathrm{C}=\mathrm{N}) ;{ }^{1} \mathrm{H}$ NMR $\left(\mathrm{d}_{6}{ }^{-}\right.$ DMSO) $\delta 8.70$ (bs, $1 \mathrm{H}, \mathrm{N}-\mathrm{H}), 7.90$ (d, $1 \mathrm{H}, J=7.5 \mathrm{~Hz}, \mathrm{H}-5)$, 7.70 (t, 1H, J = 7.5 Hz, H-6), 7.60-7.30 (m, 7H, ArH, H-7, H-8), 4.50 (s, 2H, H-9); ${ }^{13} \mathrm{C} \mathrm{NMR}$ (d $\mathrm{d}_{6}$-DMSO) $\delta 165.4$ (C-4), 154.9

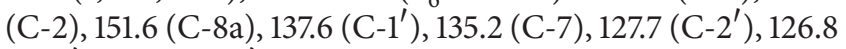
$\left(\mathrm{C}-4^{\prime}\right), 126.4\left(\mathrm{C}-3^{\prime}\right), 124.3$ (C-5), 124.7 (C-6), 124.5 (C-8), 117.0 (C-4a), 43.8 (C-9); Anal. Calcd. For $\mathrm{C}_{15} \mathrm{H}_{12} \mathrm{~N}_{2} \mathrm{O}_{2}$ : C, 71.42; $\mathrm{H}$, 4.79; N, 11.10. Found: C, 71.65; H, 4.95; N, 11.25.
2-(Benzyl amino)-8-methyl-4H-benz[e]-1,3-oxazin-4-one $\mathbf{1 5 b}$. 8-Methyl-2-(methylthio)-4H-benz[e]-1,3-oxazin-4-one $\mathbf{1 4 b}$ was allowed to react with benzyl amine according to general procedure D. The crude solid was collected and recrystallized from ethyl acetate to give $\mathbf{1 5 b}$ ( $72 \%$ yield), mp $257-258^{\circ} \mathrm{C} . \nu_{\max }$ $(\mathrm{KBr}) / \mathrm{cm}^{-1}$ 3062, $2883(\mathrm{~N}-\mathrm{H}), 1678$ (C=O), 1639 (C=C), 1482 $(\mathrm{C}=\mathrm{N}) ;{ }^{1} \mathrm{H}$ NMR $\left(\mathrm{d}_{6}\right.$-DMSO) $\delta 8.80(\mathrm{bs}, 1 \mathrm{H}, \mathrm{N}-\mathrm{H}), 7.70(\mathrm{~d}$, $1 \mathrm{H}, J=7.5 \mathrm{~Hz}, \mathrm{H}-5), 7.50$ (d, $1 \mathrm{H}, J=7.5 \mathrm{~Hz}, \mathrm{H}-7), 7.40-7.20$ (m, ArH/H-6), 4.50 (s, 2H, H-9) 2.30 (s, 3H, 8- $\left.\mathrm{CH}_{3}\right) ;{ }^{13} \mathrm{C}$ NMR $\left(\mathrm{d}_{6}\right.$-DMSO) $\delta 165.4(\mathrm{C}-4), 157.9(\mathrm{C}-2), 151.6(\mathrm{C}-8 \mathrm{a}), 137.6(\mathrm{C}-$ $\left.1^{\prime}\right), 134.2$ (C-7), $127.7\left(\mathrm{C}-2^{\prime}\right), 126.8\left(\mathrm{C}-4^{\prime}\right), 126.4\left(\mathrm{C}-3^{\prime}\right), 124.3$ (C-5), 124.7 (C-6), 124.5 (C-8), 117.0 (C-4a), 43.8 (C-9), 13.5 $\left(\mathrm{CH}_{3}\right)$; Anal. Calcd. For $\mathrm{C}_{16} \mathrm{H}_{14} \mathrm{~N}_{2} \mathrm{O}_{2}: \mathrm{C}, 72.16$; H, 5.30; N, 10.52. Found: C, 72.10; H, 5.38; N, 10.25.

2-(Benzyl amino)-8-phenyl-4H-benz[e]-1,3-oxazin-4-one 15c. 8-Phenyl-2-(methylthio)-4H-benz[e]-1,3-oxazin-4-one 14c was allowed to react with benzyl amine according to general procedure $\mathrm{D}$. The crude solid was collected and recrystallized from ethanol to give 15c (65\% yield), $\mathrm{mp}$ $215^{\circ} \mathrm{C} . v_{\max }(\mathrm{KBr}) / \mathrm{cm}^{-1} 3040,2860(\mathrm{~N}-\mathrm{H}), 1679(\mathrm{C}=\mathrm{O})$, $1635(\mathrm{C}=\mathrm{C}), 1489(\mathrm{C}=\mathrm{N}) ;{ }^{1} \mathrm{H}$ NMR $\left(\mathrm{d}_{6}\right.$-DMSO) $\delta 9.20$ (bs, $1 \mathrm{H}, \mathrm{N}-\mathrm{H}), 7.90$ (d, $1 \mathrm{H}, J=7.5 \mathrm{~Hz}, \mathrm{H}-5), 7.70-7.20(\mathrm{~m}, 11 \mathrm{H}$, ArH/ArH/H-7), 7.90 (d, 1H, J = 3.0 Hz, H-6), 4.50 (s, 2H, $\mathrm{H}-9) ;{ }^{13} \mathrm{C}$ NMR (d $\mathrm{d}_{6}$-DMSO) $\delta 165.1$ (C-4), 157.9 (C-2), 151.2 (C-8a), 137.6 (C-1 $\left.{ }^{\prime}\right), 134.7$ (C-7), 134.1 (C-5), 129.2-125.8 (C-2', C-4' C-3', C-8 C-9, C-10 C-11, C-12), 124.8 (C-6), 117.7 (C-4a), 43.9 (C-9); Anal. Calcd. For $\mathrm{C}_{21} \mathrm{H}_{16} \mathrm{~N}_{2} \mathrm{O}_{2} 0.5 \mathrm{H}_{2} \mathrm{O}: \mathrm{C}$, 76.81; H, 4.91; N, 8.53. Found: C, 74.31; H, 4.99; N, 8.46.

2-(Benzyl amino)-7-methoxy-4H-1,3-benzoxazin-4-one 15d. 7-Methoxy-2-(methylthio)-4H-benz[e]-1,3-oxazin-4-one

14d was allowed to react with benzylamine according to general procedure $\mathrm{D}$. The crude solid was collected and recrystallised from toluene to give $\mathbf{1 5 d}$ (83\% yield), $\mathrm{mp}$ 234-236 ${ }^{\circ}$ C. $\nu_{\max }(\mathrm{KBr}) / \mathrm{cm}^{-1} 3069-2891(\mathrm{~N}-\mathrm{H}), 1678(\mathrm{C}=\mathrm{O})$, $1619(\mathrm{C}=\mathrm{C}), 1499(\mathrm{C}=\mathrm{N}) ;{ }^{1} \mathrm{H}$ NMR $\left(\mathrm{d}_{6}\right.$-DMSO) $\delta 9.00$ (bs, $1 \mathrm{H}, \mathrm{N}-\mathrm{H}), 7.80$ (d, $1 \mathrm{H}, J=8.6 \mathrm{~Hz}, \mathrm{H}-5), 7.30$ (m, 5H, ArH), $6.90\left(\mathrm{dd}, 1 \mathrm{H}, J_{\mathrm{H} 6, \mathrm{H} 8}=2.4 \mathrm{~Hz}, J_{\mathrm{H} 6, \mathrm{H} 5}=8.6 \mathrm{~Hz}, \mathrm{H}-6\right), 6.70(\mathrm{~d}$, $1 \mathrm{H}, J=2.2 \mathrm{~Hz}, \mathrm{H}-8), 4.50$ (s, 2H, H-9), 3.90 (s, 3H, 7- $\mathrm{OCH}_{3}$ ); ${ }^{13} \mathrm{C}$ NMR (d $\mathrm{d}_{6}$-DMSO) $\delta 164.7$ (C-4), 163.3 (C-7), 157.9 (C-2), 154.5 (C-8a), 137.6 (C-1' $), 127.7$ (C-5), 127.6 (C-2' $), 126.7$ $\left(\mathrm{C}-4^{\prime}\right), 126.4\left(\mathrm{C}-3^{\prime}\right), 112.2(\mathrm{C}-6), 110.6$ (C-4a), 99.3 (C-8), 55.4 $\left(\mathrm{OCH}_{3}\right), 43.7$ (C-9); Anal. Calcd. For $\mathrm{C}_{16} \mathrm{H}_{14} \mathrm{~N}_{2} \mathrm{O}_{3}$ : C, 68.07; H, 5.00; N, 9.92. Found: C, 67.86; H, 4.89; N, 10.01 .

2-(Benzyl amino)-7-ethoxy-4H-1,3-benzoxazin-4-one 15e. 7Ethoxy-2-(methylthio)-4H-benz[e]-1,3-oxazin-4-one $\mathbf{1 4 e}$ was allowed to react with benzylamine according to general procedure D. The crude solid was collected and recrystallized from toluene to give $15 \mathrm{e}$ (80\% yield), mp $214-216^{\circ} \mathrm{C} . v_{\max }$ $(\mathrm{KBr}) / \mathrm{cm}^{-1}$ 3069-2827 (N-H), $1673(\mathrm{C}=\mathrm{O}), 1600(\mathrm{C}=\mathrm{C})$, $1466(\mathrm{C}=\mathrm{N}) ;{ }^{1} \mathrm{H}$ NMR (d $\left.{ }_{6}-\mathrm{DMSO}\right) \delta 9.00$ (bs, $\left.1 \mathrm{H}, \mathrm{N}-\mathrm{H}\right)$, 7.80 (d, $1 \mathrm{H}, J=8.6 \mathrm{~Hz}, \mathrm{H}-5), 7.30$ (m, 5H, ArH), 6.90 (dd, $\left.1 \mathrm{H}, J_{\mathrm{H} 6, \mathrm{H} 8}=2.4 \mathrm{~Hz}, J_{\mathrm{H} 6, \mathrm{H} 5}=8.6 \mathrm{~Hz}, \mathrm{H}-6\right), 6.70(\mathrm{~d}, 1 \mathrm{H}, J=$ $2.2 \mathrm{~Hz}, \mathrm{H}-8$ ), 4.50 (s, 2H, H-9), 4.20 (q, 2H, J = 5.6, $\mathrm{CH}_{2}-\mathrm{O}$ ), $3.90\left(\mathrm{~s}, 3 \mathrm{H}, 7-\mathrm{OCH}_{3}\right), 1.30\left(\mathrm{t}, 3 \mathrm{H}, \mathrm{J}=5.6, \mathrm{CH}_{3}\right) ;{ }^{13} \mathrm{C} \mathrm{NMR}$ $\left(\mathrm{d}_{6}\right.$-DMSO) $\delta 164.4(\mathrm{C}-4), 163.1(\mathrm{C}-7), 157.9(\mathrm{C}-2), 154.9(\mathrm{C}-$ 8a), 137.8 (C-1' $), 127.6$ (C-5), $127.5\left(\mathrm{C}-2^{\prime}\right), 126.7$ (C-4 $\left.{ }^{\prime}\right), 126.4$ 
$\left(\mathrm{C}-3^{\prime}\right), 112.6$ (C-6), $110.3(\mathrm{C}-4 \mathrm{a}), 99.8(\mathrm{C}-8), 63.6\left(\mathrm{CH}_{2}-\mathrm{O}\right)$, 43.7 (C-9), $13.5\left(\mathrm{CH}_{3}\right)$; Anal. Calcd. For $\mathrm{C}_{17} \mathrm{H}_{16} \mathrm{~N}_{2} \mathrm{O}_{3}$ : C, 68.91; H, 5.44; N, 9.45. Found: C, 69.11; H, 5.76; N, 9.28.

2-(Benzyl amino)-7-hydroxy-4H-1,3-benzoxazin-4-one $\mathbf{1 5 f}$. 7-Hydroxy-2-(methylthio)-4H-benz[e]-1,3-oxazin-4-one $\mathbf{1 4 f}$ was allowed to react with benzyl amine according to general procedure D. The crude solid was collected and recrystallized from ethanol to give $\mathbf{1 5 f}$ (77\% yield), mp decomp $262^{\circ} \mathrm{C}$. $v_{\max }(\mathrm{KBr}) / \mathrm{cm}^{-1} 3300-3058(\mathrm{O}-\mathrm{H}), 3058-2851(\mathrm{~N}-\mathrm{H}), 1667 \mathrm{~s}$ $(\mathrm{C}=\mathrm{O}), 1607 \mathrm{~m}(\mathrm{C}=\mathrm{C}), 1543 \mathrm{~s}(\mathrm{C}=\mathrm{N}) ;{ }^{1} \mathrm{H}$ NMR $\left(\mathrm{d}_{6}\right.$-DMSO) $\delta 8.70$ (bs, $1 \mathrm{H}, \mathrm{N}-\mathrm{H}), 7.50$ (d, $1 \mathrm{H}, J=8.6 \mathrm{~Hz}, \mathrm{H}-5), 7.30-7.20$ (m, 6H, ArH/7-OH), 6.50 (d, 1H, $J=8.6 \mathrm{~Hz}, \mathrm{H}-6), 6.30$ (s, $1 \mathrm{H}, \mathrm{H}-8), 4.50$ (s, 2H, H-9); ${ }^{13} \mathrm{C}$ NMR (d $\mathrm{d}_{6}$-DMSO) $\delta 169.6$ (C-4), 166.1 (C-7), 158.1 (C-2), 155.8 (C-8a), 138.5 (C-1' $\left.^{\prime}\right), 128.3$ $\left(\mathrm{C}-2^{\prime}\right), 127.7\left(\mathrm{C}-4^{\prime}\right), 127.2\left(\mathrm{C}-3^{\prime}\right), 127.0$ (C-5), 116.1 (C-6), 104.9 (C-4a), 100.6 (C-8), 43.7 (C-9); Anal. Calcd. For $\mathrm{C}_{15} \mathrm{H}_{12} \mathrm{~N}_{2} \mathrm{O}_{3}$ : C, 67.16; H, 4.51; N, 10.44. Found: C, 67.14; H, 4.34; N, 10.49 .

2-(Benzyl amino)-7-hydroxy-8-methyl-4H-1,3-benzoxazin-4one 15g. 7-Hydroxy-8-methyl-2-(methylthio)-4H-benz[e]1,3-oxazin-4-one $\mathbf{1 4} \mathbf{g}$ was allowed to react with benzylamine according to general procedure $\mathrm{D}$. The crude solid was collected and recrystallised from ethanol to give $15 \mathrm{~g}(74 \%$ yield), mp $245-247^{\circ}$ C. $v_{\max }(\mathrm{KBr}) / \mathrm{cm}^{-1} 3300-2860(\mathrm{O}-\mathrm{H})$, 3058-2851 (N-H), $1678(\mathrm{C}=\mathrm{O}), 1608 \mathrm{~m}(\mathrm{C}=\mathrm{C}), 1549 \mathrm{~s}(\mathrm{C}=\mathrm{N})$; ${ }^{1} \mathrm{H}$ NMR $\left(\mathrm{d}_{6}\right.$-DMSO) $\delta 8.70(\mathrm{bs}, 1 \mathrm{H}, \mathrm{N}-\mathrm{H}), 7.60(\mathrm{~d}, 1 \mathrm{H}, J=$ $8.6 \mathrm{~Hz}, \mathrm{H}-5), 7.30-7.20$ (m, 6H, H-2'/H-3'/H-4'/7-OH), 6.80 $(\mathrm{d}, 1 \mathrm{H}, J=8.6 \mathrm{~Hz}, \mathrm{H}-6), 4.50$ (s, $2 \mathrm{H}, \mathrm{H}-9) ;{ }^{13} \mathrm{C} \mathrm{NMR}\left(\mathrm{d}_{6}-\right.$ DMSO) $\delta 165.2$ (C-4), 159.6 (C-7), 157.8 (C-2), 152.5 (C-8a), $137.8\left(\mathrm{C}-1^{\prime}\right), 127.6\left(\mathrm{C}-2^{\prime}\right), 126.7\left(\mathrm{C}-4^{\prime}\right), 126.4\left(\mathrm{C}-3^{\prime}\right), 124.2(\mathrm{C}-$ 5), 112.0 (C-6), 109.4 (C-8), 108.1 (C-4a), 43.7 (C-9), 6.8 (8$\mathrm{CH}_{3}$ ); Anal. Calcd. For $\mathrm{C}_{16} \mathrm{H}_{14} \mathrm{~N}_{2} \mathrm{O}_{3}$ : C, 68.07; H, 5.00; N, 9.92. Found: C, 67.86; $\mathrm{H}, 5.28 ; \mathrm{N}, 9.68$.

N-(2-(Benzylamino)-4-oxo-4H-benz[e][1,3]oxazin-7-yl)acetamide 15h. In modification to the general procedure D, N-(2(methylthio)-4-oxo-4H-benz[e][1,3] oxazin-7-yl)acetamide $14 \mathbf{i}(0.26 \mathrm{~g} 1 \mathrm{mmol})$ was allowed to react with benzylamine $(0.2 \mathrm{~mL}, 1 \mathrm{mmol})$ for 4 hours. The resulting solid was collected and recrystallised from acetonitrile to give $\mathbf{1 5} \mathbf{h}$ $(0.1,47 \%)$ as white crystals, mp $250-253^{\circ} \mathrm{C}$. decomp. $v_{\max }$ $(\mathrm{KBr}) / \mathrm{cm}^{-1}$ 3284, 3234, $3215(\mathrm{NH}), 1669(\mathrm{C}=\mathrm{O})$; ${ }^{1} \mathrm{HNMR}$ $\left(200 \mathrm{MHz}, 390 \mathrm{~K}, \mathrm{~d}_{6}\right.$-DMSO) $\delta 10.28(\mathrm{~s}, 1 \mathrm{H}, \mathrm{H}-15), 8.86(\mathrm{t}$, $\left.1 \mathrm{H}, J_{\mathrm{H} 9, \mathrm{H} 10}=4.7 \mathrm{~Hz}, \mathrm{H}-9\right), 7.81-7.78(\mathrm{~m}, 2 \mathrm{H}, \mathrm{H}-8$ and $\mathrm{H}-5)$, 7.37-7.26 (m, 6H, Ar, H-12-14 and H-6), $4.52\left(\mathrm{~d}, 2 \mathrm{H}, J_{\mathrm{H} 10, \mathrm{H} 9}=\right.$ $4.7 \mathrm{~Hz}, \mathrm{H}-10), 2.10$ (s, 3H, 17- $\left.\mathrm{CH}_{3}\right) ;{ }^{13} \mathrm{C} \mathrm{NMR}(50 \mathrm{MHz}, 390 \mathrm{~K}$, $\mathrm{d}_{6}$-DMSO) $\delta 169.3$ (C-16), 165.4 (C-4), 158.4 (C-8a), 154.2 (C-2), 144.3 (C-7), 138.2 (C-11), 128.4 (C-5), 127.5/127.3/127.2 (C-12/C-13/C-14), 115.7 (C-6), 112.1 (C-4a), 104.2 (C-8), 44.0 (C-10), 24.3 (C-17); Anal. Calcd. For $\mathrm{C}_{17} \mathrm{H}_{15} \mathrm{~N}_{3} \mathrm{O}_{3}$ : C, 66.01; $\mathrm{H}, 4.89 ; \mathrm{N}, 13.58$. Found: C, 65.93; H, 5.02; N, 13.52 .

4.1.14. 10-Methyl-2,8-bis(methylthio)benzo[1,2-e:5,4-e']bis([1, 3]oxazine)-4,6-dione 24. Following the previously reported [35], 10-methyl-2, 8-dithioxo-2, 3, 7, 8-tetrahydrobenzo[1,2$\left.e: 5,4-e^{\prime}\right]$ bis([1,3] oxazine)-4,6-dione 18c $(0.74 \mathrm{~g}, 2.5 \mathrm{mmol})$ was allowed to react with methyl iodide $(5.4 \mathrm{~mL}, 86.8 \mathrm{mmol})$ and $\mathrm{NaHCO}_{3}(3.0 \mathrm{~g}, 32 \mathrm{mmol})$ for $2 \mathrm{hrs}$. The resulting yellow solid $24(0.78 \mathrm{~g}, 98 \%)$ is collected and used without further purification. $\mathrm{mp}>300^{\circ} \mathrm{C}$ decomp. $v_{\max }(\mathrm{KBr}) / \mathrm{cm}^{-1} 1623$ $(\mathrm{C}=\mathrm{O}), 1548(\mathrm{C}=\mathrm{N}) ;{ }^{1} \mathrm{H}$ NMR $\left(200 \mathrm{MHz}, 390 \mathrm{~K}, \mathrm{~d}_{6}\right.$-DMSO) $\delta$ 8.27 (s, 1H, H-5), 2.64 (s, 6H, H-3' and H-9'), 2.33 (s, 3H, H$\left.10^{\prime}\right) .{ }^{13} \mathrm{C}$ NMR $\left(50 \mathrm{MHz}, 390 \mathrm{~K}, \mathrm{~d}_{6}\right.$-DMSO) $\delta 173.0(\mathrm{C}-2,8)$, 160.6 (C-4,6), 155.3 (C-6a, 9a), 124.0 (C-5) 123.6 (C-10), 115.2 (C-4a, 5a), $13.4\left(\mathrm{C}-3^{\prime}, 9^{\prime}\right), 6.7\left(\mathrm{C}-10^{\prime}\right)$.

4.1.15. 2,8-Bis(benzylamino)-10-methylbenzo[1,2-e:5,4-e $e^{\prime}$ bis ([1,3]oxazine)-4,6-dione 26. In slight modification to the general procedure $\mathrm{D}, 10$-methyl-2,8-bis(methylthio) benzo bis([1,3] oxazine)-4,6-dione $24(0.29 \mathrm{~g}, 1 \mathrm{mmol})$ was allowed to react with benzyl amine $0.4 \mathrm{~mL},(2 \mathrm{mmol})$ for 16 hours. The resulting solid was collected and recrystallised from DMSO/water to give $26(0.25 \mathrm{~g}, 56 \%)$ as an off white solid, $\mathrm{mp}$ $285-288^{\circ} \mathrm{C}$ decomp. $v_{\max }(\mathrm{KBr}) / \mathrm{cm}^{-1} 3394,3202,3029(\mathrm{NH})$, 1681, 1635 (C=O); ${ }^{1} \mathrm{HNMR}\left(200 \mathrm{MHz}, 340 \mathrm{~K}, \mathrm{~d}_{6}\right.$-DMSO) $\delta$ 8.90 (bs, 2H, H-11,17), 8.27 (s, 1H, H-5), 7.43-7.24 (m, $10 \mathrm{H} 2$ x Ar, H-14-16 and H-20-22), 4.58 (s, 4H, H-12,18), 2.31 (s, $\left.3 \mathrm{H}, \mathrm{H}-10^{\prime}\right) ;{ }^{13} \mathrm{C}$ NMR (50 MHz, $340 \mathrm{~K}, \mathrm{~d}_{6}$-DMSO) $\delta 164.0$ (C-4), 164.0 (C-9a,10a), 157.6 (C-2), 137.2 (C-13,19), 127.7, 126.9, 126.6, 122.5 (C-15,21, C-14,20 and C-16,22), 113.9 (C10), 115.5 (C-4a,5a), 44.0 (C-12,17), 6.6 (C-10'); Anal. Calcd. For $\mathrm{C}_{25} \mathrm{H}_{20} \mathrm{~N}_{4} \mathrm{O}_{4} \cdot 2 \mathrm{H}_{2} \mathrm{O}$ : C, 63.02; H, 5.08; N, 11.76. Found: C, 63.22; H, 4.99; N, 11.96 .

\subsubsection{Synthesis of Substituted-1,3-benzoxazine-diones $22 a-h$ and 25}

General Procedure F. The appropriate substituted methylthio1,3-benzoxazine $2.5 \mathrm{mmol}$ was hydrolysed with $10 \mathrm{~mL}$ hydrochloric acid (10\%) at $80^{\circ} \mathrm{C}$ for 4 hours. At the completion of the reaction, the reaction mixture was washed with R.O water, filtered, and recrystallised from an appropriate solvent.

Products 22a-h were used in the synthesis of products 23a-h with no further purification.

2H-Benz[e]-1,3-oxazin-2,4(3H)-dione 22a. 2-(Methylthio)$4 H$-benz[e]-1,3-oxazin-4-one $\mathbf{1 4 a}$ was allowed to react with hydrochloric acid (10\%) according to general procedure $\mathrm{F}$. The crude solid was collected and recrystallised from ethanol to give $22 \mathbf{a}\left(75 \%\right.$ yield), $\mathrm{mp} 228^{\circ} \mathrm{C}$. (lit. $\left.[19,20] 229-230^{\circ} \mathrm{C}\right)$. $\nu_{\max }(\mathrm{KBr}) / \mathrm{cm}^{-1} 3179,2877(\mathrm{~N}-\mathrm{H}), 1771(\mathrm{C}=\mathrm{O}), 1690(\mathrm{C}=\mathrm{O})$, $1610(\mathrm{C}=\mathrm{C}) ;{ }^{1} \mathrm{H}$ NMR $\left(200 \mathrm{MHz}, \mathrm{d}_{6}\right.$-DMSO) $\delta 7.90(\mathrm{~d}, 1 \mathrm{H}, J=$ $7.5 \mathrm{~Hz}, \mathrm{H}-5), 7.80$ (t, 1H, J = 7.5 Hz, H-6), 7.40 (m, 2H, H-7/H-

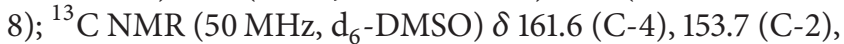
147.6 (C-8a), 136.2 (C-7), 126.9 (C-5), 125.2 (C-6), 116.5 (C-8), $114.6(\mathrm{C}-4 \mathrm{a})$.

8-Methyl-2H-benz[e]-1,3-oxazin-2,4(3H)-dione 22b. 8-Methyl-2-(methylthio)-4H-benz[e]-1,3-oxazin-4-one $\mathbf{1 4 b}$ was allowed to react with hydrochloric acid (10\%) according to general procedure $\mathrm{F}$. The crude solid was collected and recrystallised from ethanol to give $22 \mathbf{b}$ ( $85 \%$ yield), $\mathrm{mp} 210^{\circ} \mathrm{C}$ (lit. $\left.[19,20] 210-212^{\circ} \mathrm{C}\right) . v_{\max }(\mathrm{KBr}) / \mathrm{cm}^{-1} 3221,2845(\mathrm{~N}-\mathrm{H})$, $1746(\mathrm{C}=\mathrm{O}), 1717(\mathrm{C}=\mathrm{O}), 1614(\mathrm{C}=\mathrm{C}) ;{ }^{1} \mathrm{H}$ NMR $(200 \mathrm{MHz}$, $\mathrm{d}_{6}$-DMSO) $\delta 8.80$ (bs, $\left.1 \mathrm{H}, \mathrm{N}-\mathrm{H}\right), 7.70$ (d, 1H, $\left.J=7.5 \mathrm{~Hz}, \mathrm{H}-5\right)$, 
$7.60(\mathrm{~d}, 1 \mathrm{H}, J=7.5 \mathrm{~Hz}, \mathrm{H}-7), 7.30-7.20$ (t, $1 \mathrm{H}, J=7.1 \mathrm{~Hz}, \mathrm{H}-6)$, $2.30\left(\mathrm{~s}, 3 \mathrm{H}, 8-\mathrm{CH}_{3}\right) ;{ }^{13} \mathrm{C}$ NMR (50 MHz, d 6 -DMSO) $\delta 161.6$ (C-4), 151.9 (C-2), 147.3 (C-8a), 136.9 (C-7), 125.5 (C-8), 124.6 (C-5), 124.4 (C-6), $114.4(\mathrm{C}-4 \mathrm{a}), 13.8\left(\mathrm{CH}_{3}\right)$.

7-Methoxy-2H-benz[e]-1,3-oxazin-2,4(3H)-dione 22c. 7-Methoxy-2-(methylthio)-4H-benz[e]-1,3-oxazin-4-one 14d was allowed to react with hydrochloric acid (10\%) according to general procedure $\mathrm{F}$. The crude solid was collected and recrystallised from ethyl acetate to give 22c (78\% yield), $\mathrm{mp}$ $213^{\circ} \mathrm{C} . v_{\max }(\mathrm{KBr}) / \mathrm{cm}^{-1} 3203,2930(\mathrm{~N}-\mathrm{H}), 1771(\mathrm{C}=\mathrm{O}), 1723$ $(\mathrm{C}=\mathrm{O}), 1620$ (C=C); ${ }^{1} \mathrm{H}$ NMR (200 MHz, $\mathrm{d}_{6}$-DMSO) $\delta 12.10$ (s, 1H, N-H), $7.90(\mathrm{~d}, 1 \mathrm{H}, J=8.3 \mathrm{~Hz}, 5-\mathrm{H}), 7.10(\mathrm{~s}, 1 \mathrm{H}, 8-\mathrm{H})$, $7.00(\mathrm{~d}, 1 \mathrm{H}, J=8.3 \mathrm{~Hz}, 6-\mathrm{H}), 3.0\left(\mathrm{~s}, 3 \mathrm{H}, 7-\mathrm{OCH}_{3}\right) ;{ }^{13} \mathrm{C} \mathrm{NMR}$ (50 MHz, d 6 -DMSO) $\delta 160.6$ (C-4), 157.9 (C-2), 155.4 (C-7), 151.6 (C-8a), 128.2 (C-5), 113.2 (C-6), 107.1 (C-4a), 100.8 (C-8), $56.5\left(7-\mathrm{OCH}_{3}\right)$; Anal. Calcd. For $\mathrm{C}_{9} \mathrm{H}_{7} \mathrm{NO}_{4}$ : C, 55.96; H, 3.65; N, 7.25. Found: C, 55.75; H, 3.45; N, 7.55.

7-Ethoxy-2H-benz[e]-1,3-oxazin-2,4(3H)-dione 22d. 7-Ethoxy-2-(methylthio)- $4 H$-benz $[e]-1,3$-oxazin-4-one $14 \mathbf{e}$ was allowed to react with hydrochloric acid (10\%) according to general procedure $\mathrm{F}$. The crude solid was collected and recrystallised from ethyl acetate to give 22e (75\% yield), mp 225-227 ${ }^{\circ}$ C. $\nu_{\max }(\mathrm{KBr}) / \mathrm{cm}^{-1} 3157-2862(\mathrm{~N}-\mathrm{H}), 1771(\mathrm{C}=\mathrm{O})$, 1698 (C=O), 1620 (C=C); ${ }^{1} \mathrm{H}$ NMR (200 MHz, d $\mathrm{d}_{6}$-DMSO) $\delta$ 11.90 (bs, $1 \mathrm{H}, \mathrm{N}-\mathrm{H}$ ), 7.80 (d, $1 \mathrm{H}, J=8.6 \mathrm{~Hz}, \mathrm{H}-5), 6.90$ (m, 2H, $\mathrm{H}-6 / \mathrm{H}-8), 4.10\left(\mathrm{q}, 2 \mathrm{H}, J=6.8 \mathrm{~Hz}, \mathrm{O}-\mathrm{CH}_{2}\right), 1.30(\mathrm{t}, 3 \mathrm{H}, J=$ $\left.6.8 \mathrm{~Hz}, \mathrm{CH}_{3}\right) ;{ }^{13} \mathrm{C}$ NMR (50 MHz, $\mathrm{d}_{6}$-DMSO) $\delta 164.6(\mathrm{C}-4)$, 160.9 (C-2), 155.4 (C-7), 147.6 (C-8a), 128.2 (C-5), 113.2 (C-6), 107.1 (C-4a), 100.8 (C-8), $64.4\left(\mathrm{CH}_{2}-\mathrm{O}\right), 14.3\left(\mathrm{CH}_{3}\right)$; Anal. Calcd. For $\mathrm{C}_{10} \mathrm{H}_{9} \mathrm{NO}_{4}$ : C, 57.97; $\mathrm{H}, 4.38 ; \mathrm{N}, 6.76$. Found: $\mathrm{C}$, $57.86 ; \mathrm{H}, 4.45 ; \mathrm{N}, 6.55$.

7-Hydroxy-2H-benz[e]-1,3-oxazin-2,4(3H)-dione 22e. 7-Hydroxy-2-(methylthio)-4H-benz[e]-1,3-oxazin-4-one $\mathbf{1 4 f}$ was allowed to react with hydrochloric acid (10\%) according to general procedure $\mathrm{F}$. The crude solid was collected and recrystallised from ethanol to give $22 \mathrm{e}$ (65\% yield), $\mathrm{mp} 245^{\circ} \mathrm{C}$ (Lit [39] 310). $v_{\max }(\mathrm{KBr}) / \mathrm{cm}^{-1} 3200-2700(\mathrm{O}-\mathrm{H}), 3078$, $2929(\mathrm{~N}-\mathrm{H}), 1780(\mathrm{C}=\mathrm{O}), 1688(\mathrm{C}=\mathrm{O}), 1616(\mathrm{C}=\mathrm{C}) ;{ }^{1} \mathrm{H}$ NMR (200 MHz, d 6 -DMSO) $\delta 11.80(\mathrm{~s}, 1 \mathrm{H}, \mathrm{N}-\mathrm{H}), 11.00$ (s, 1H, 7-O$\mathrm{H}), 7.70(\mathrm{~d}, 1 \mathrm{H}, J=8.6 \mathrm{~Hz}, \mathrm{H}-5), 6.80(\mathrm{~d}, 1 \mathrm{H}, J=8.6 \mathrm{~Hz}, \mathrm{H}-$ 6), $6.60(\mathrm{~s}, 1 \mathrm{H}, \mathrm{H}-8) ;{ }^{13} \mathrm{C} \mathrm{NMR}\left(50 \mathrm{MHz}, \mathrm{d}_{6}\right.$-DMSO) $\delta 164.6$ (C-4), 160.9 (C-2), 155.4 (C-7), 147.6 (C-8a), 128.6 (C-5), 113.8 (C-6), 105.9 (C-4a), 101.8 (C-8); Anal. Calcd. For $\mathrm{C}_{8} \mathrm{H}_{5} \mathrm{NO}_{4}$ : C, 53.64; H, 2.81; N, 7.82. Found: C, 53.75; H, 2.45; N, 7.55.

\section{7-Hydroxy-8-methyl-2H-benz[e]-1,3-oxazin-2,4(3H)-dione}

22f. 7-Hydroxy-8-methyl-2-(methylthio)-4H-benz[e]-1,3oxazin-4-one $\mathbf{1 4} \mathbf{g}$ was allowed to react with hydrochloric acid (10\%) according to general procedure F. The crude solid was collected and recrystallised from ethanol to give $\mathbf{2 2 f}$ (70\% yield), $\mathrm{mp} 250^{\circ} \mathrm{C}$ decomp. $\nu_{\max }(\mathrm{KBr}) / \mathrm{cm}^{-1} 3250,2900$ $(\mathrm{O}-\mathrm{H}), 3188,2956(\mathrm{~N}-\mathrm{H}), 1771(\mathrm{C}=\mathrm{O}), 1713(\mathrm{C}=\mathrm{O}), 1619$ $(\mathrm{C}=\mathrm{C}) ;{ }^{1} \mathrm{H}$ NMR $\left(200 \mathrm{MHz}, \mathrm{d}_{6}\right.$-DMSO) $\delta 11.70(\mathrm{~s}, 1 \mathrm{H}, \mathrm{N}-\mathrm{H})$, 10.10 (s, 1H, 7-O-H), 7.60 (d, 1H, $J=8.4 \mathrm{~Hz}, \mathrm{H}-5), 6.80$ (d, $1 \mathrm{H}, J=8.4 \mathrm{~Hz}, \mathrm{H}-6), 2.10\left(\mathrm{~s}, 3 \mathrm{H}, 8-\mathrm{CH}_{3}\right) ;{ }^{13} \mathrm{C} \mathrm{NMR}(50 \mathrm{MHz}$, $\mathrm{d}_{6}$-DMSO) $\delta 162.4$ (C-4), 161.5 (C-2), 153.4 (C-7), 147.9
(C-8a), 125.4 (C-5), 112.6 (C-6), 110.8 (C-4a), 106.0 (C-8), 8.1 $\left(8-\mathrm{CH}_{3}\right)$; Anal. Calcd. For $\mathrm{C}_{9} \mathrm{H}_{7} \mathrm{NO}_{4}$ : C, 55.96; H, 3.65; N, 7.25. Found: C, 55.75; H, 3.45; N, 7.55.

N-(2,4-Dioxo-3,4-dihydro-2H-benz[e][1,3]oxazin-7-yl)acetamide $22 \mathrm{~g}$. In slight modification to the general procedure F, $N$-(2-(methylthio)-4-oxo-4H-benz[e][1,3] oxazin-7yl) acetamide $14 \mathbf{i}(0.63 \mathrm{~g}, 2.5 \mathrm{mmol})$ was allowed to reflux with water $(10 \mathrm{~mL})$ for 2 hours. The resulting crude solid was filtered, and recrystallised from methanol to give $\mathbf{2 2} \mathbf{g}$ (0.52 g, 95\%) as light grey solid, mp $284-287^{\circ} \mathrm{C}$ (Lit [39]. 310$14^{\circ}$ decomp.). $v_{\max }(\mathrm{KBr}) / \mathrm{cm}^{-1} 3350,3050(\mathrm{NH}), 1758,1704$ $(\mathrm{C}=\mathrm{O}) ;{ }^{1} \mathrm{HNMR}\left(200 \mathrm{MHz}, 340 \mathrm{~K}, \mathrm{~d}_{6}\right.$-DMSO) $\delta 11.80$ (bs, $1 \mathrm{H}$, 3-NH), 10.57 (s, 1H, 9-NH), $7.83\left(\mathrm{~d}, 1 \mathrm{H}, J_{\mathrm{H} 5, \mathrm{H} 6}=8.6 \mathrm{~Hz}, \mathrm{H}-\right.$ 5), $7.72\left(\mathrm{~d}, 1 \mathrm{H}, J_{\mathrm{H} 8, \mathrm{H} 6}=1.6 \mathrm{~Hz}, \mathrm{H}-8\right), 7.45\left(\mathrm{dd}, 1 \mathrm{H}, J_{\mathrm{H} 6, \mathrm{H} 5}=\right.$ $\left.8.6 \mathrm{~Hz}, J_{\mathrm{H} 6, \mathrm{H} 8}=1.6 \mathrm{~Hz}, \mathrm{H}-6\right), 2.11\left(\mathrm{~s}, 3 \mathrm{H}, 11-\mathrm{CH}_{3}\right) ;{ }^{13} \mathrm{C} \mathrm{NMR}$ (50 MHz, $340 \mathrm{~K}, \mathrm{~d}_{6}$-DMSO) $\delta 169.0$ (C-10), 160.3 (C-4), 154.2 (C-2), 147.1, 145.7 (C-8a, C-7), 127.3 (C-5), 115.3 (C-6), 108.6 (C-4a), 104.6 (C-8), 23.5 (C-11). Anal. Calcd. For $\mathrm{C}_{10} \mathrm{H}_{8} \mathrm{~N}_{2} \mathrm{O}_{4}$ : C, 54.55; H, 3.66; N, 12.72. Found: C, 54.49; H, 3.77; N, 12.69 .

7-Amino-2H-benz[e][1,3]oxazine-2,4(3H)-dione 22h. In modification to the general procedure $\mathrm{F}, \mathrm{N}$-(2-(methylthio)4-oxo-4H-benzo[e][1,3] oxazin-7-yl) acetamide $\mathbf{1 4 h}(0.63 \mathrm{~g}$, $2.5 \mathrm{mmol}$ ) was allowed to react in the presence of hydrochloric acid $(15 \mathrm{~mL}, 40 \%)$ for 4 hours. At the completion of the reaction, the reaction mixture was neutralized by $\mathrm{NaHCO}_{3}$, filtered and recrystallised from ethanol to give $\mathbf{2 2} \mathbf{h}(0.34 \mathrm{~g}$, 79\%), mp $284-287^{\circ} \mathrm{C}$ decomp. $v_{\max }(\mathrm{KBr}) / \mathrm{cm}^{-1} 3479,3372$ $(\mathrm{NH}), 2843(\mathrm{NH}), 1752,1708(\mathrm{C}=\mathrm{O})$; ${ }^{1} \mathrm{HNMR}(200 \mathrm{MHz}$, $340 \mathrm{~K}, \mathrm{~d}_{6}$-DMSO) $\delta 11.49(\mathrm{~s}, 1 \mathrm{H}, 3-\mathrm{NH}), 7.54\left(\mathrm{~d}, 1 \mathrm{H}, J_{\mathrm{H} 5, \mathrm{H} 6}\right.$ $=8.4 \mathrm{~Hz}, \mathrm{H}-5), 6.52\left(\mathrm{~m}, 3 \mathrm{H}, \mathrm{H}-6\right.$ and $\left.7-\mathrm{NH}_{2}\right), 6.31(\mathrm{~s}, 1 \mathrm{H}, \mathrm{H}-$ 8). ${ }^{13} \mathrm{C} \mathrm{NMR}\left(50 \mathrm{MHz}, 340 \mathrm{~K}, \mathrm{~d}_{6}\right.$-DMSO) $\delta 160.8$ (C-4), 156.0, 155.6 (C-2, C-7), 147.9 (C-8a), 127.8 (C-5), 111.4 (C-6), 101.5 (C4a), 97.3 (C-8). Compound $22 \mathrm{~h}$ was used for the synthesis of compound $23 \mathrm{~g}$ with no further purification.

10-Methyl-2H,6H-[1,3]oxazino[5,6-g][1,3]benzoxazine-2,4,6, $8(3 \mathrm{H}, 7 \mathrm{H})$-tetrone 25. 10-Methyl-2,8-bis(methylthio)benzo bis([1,3] oxazine)-4,6-dione $24(0.74 \mathrm{~g}, 2.5 \mathrm{mmol})$ was allowed to react with hydrochloric acid (10\%) for 4 hours according to the general procedure $\mathrm{F}$. The resulting solid was recrystallised from DMF to give $25(0.55 \mathrm{~g}, 85 \%)$ as off white crystals. $\mathrm{mp}>300^{\circ} \mathrm{C}$ decomp. $v_{\max }(\mathrm{KBr}) / \mathrm{cm}^{-1} 3183$, 3119, $3049(\mathrm{NH}), 1784,1714(\mathrm{C}=\mathrm{O}), 1616$ (C=C); ${ }^{1} \mathrm{HNMR}$ (200 MHz, $340 \mathrm{~K}, \mathrm{~d}_{6}$-DMSO) $\delta 12.18$ (bs, 2H, 3,7-NH), 8.26 (s, 1H, H-5), 2.31 (s, 3H, H-10'); ${ }^{13} \mathrm{C}$ NMR $(50 \mathrm{MHz}, 340 \mathrm{~K}$, $\mathrm{d}_{6}$-DMSO) $\delta 159.7$ (C-4,6), 155.4 (C-2,8), 145.9 (C-9a,10a), 123.3 (C-5), 113.0 (C-10), 111.3 (C-4a,5a), 7.3 (C-10'); Anal. Calcd. For $\mathrm{C}_{11} \mathrm{H}_{6} \mathrm{~N}_{2} \mathrm{O}_{6}$ : C, 50.39; H, 2.31; N, 10.68. Found: C, $50.54 ; \mathrm{H}, 2.42 ; \mathrm{N}, 10.74$.

\subsubsection{Synthesis of $\mathrm{N}$-(Benzyl carbamoyl)-2-hydroxy-substitut- ed-benzamide $\mathbf{2 3 a - g}$}

General Procedure G. The appropriate 2-dione-1,3-benzoxazines $\mathbf{2 2} \mathbf{a}-\mathbf{b}$ and $\mathbf{2 2 d}-\mathbf{i}(2.5 \mathrm{mmol})$ were suspended in dry 1,4-dioxane $(10 \mathrm{~mL})$ in a $50 \mathrm{~mL}$ round-bottomed flask. Benzyl 
amine $(12.5 \mathrm{mmol})$ was then added dropwise, directly from the pipette, with stirring, and then the reaction mixture was heated to reflux for 4 hours. At the completion of the reaction, it evaporated to dryness under reduced pressure and triturated with minimal diethyl ether. The resulting solid was collected by vacuum filtration and recrystallised from an appropriate solvent.

$N$-(Benzyl carbamoyl)-2-hydroxybenzamide 23a. 2HBenz $[e]-1,3$-oxazin-2,4(3H)-dione 22a was allowed to react with benzyl amine according to general procedure $\mathrm{F}$ to give 23a which was recrystallised from ethanol (70\% yield), mp211-213 ${ }^{\circ} \mathrm{C}$. $v_{\max }(\mathrm{KBr}) / \mathrm{cm}^{-1} 3340-2940(\mathrm{O}-\mathrm{H}), 3230-$ $3161(\mathrm{~N}-\mathrm{H}), 1687(\mathrm{C}=\mathrm{O}), 1648(\mathrm{C}=\mathrm{O}) ;{ }^{1} \mathrm{H}$ NMR $(200 \mathrm{MHz}$, $\mathrm{d}_{6}$-DMSO) $\delta 11.75$ (bs, $1 \mathrm{H}, \mathrm{H}-2^{\prime}$ ), 10.40 (bs, 1H, 1-OH), 9.05 $\left(\mathrm{t}, 1 \mathrm{H}, J=5.6 \mathrm{~Hz}, 4^{\prime}-\mathrm{NH}\right), 7.90(\mathrm{~d}, 1 \mathrm{H}, J=7.7 \mathrm{~Hz}, \mathrm{H}-3), 7.50$ (m, 1H, H-5), 7.30-7.20 (m, 5H, ArH), 7.05-6.95 (m, 2H, $\mathrm{H}-4 / \mathrm{H}-6), 4.40\left(\mathrm{~d}, 2 \mathrm{H}, J=5.2 \mathrm{~Hz}, \mathrm{H}-5^{\prime}\right) ;{ }^{13} \mathrm{C} \mathrm{NMR}(50 \mathrm{MHz}$,

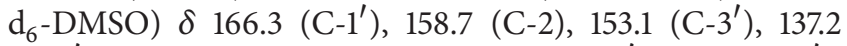
$\left(\mathrm{C}-6^{\prime}\right), 133.7$ (C-4), 130.8 (C-6), $128.4\left(\mathrm{C}-8^{\prime}\right), 127.3\left(\mathrm{C}-7^{\prime}\right)$, 127.0 (C-9' $), 119.9$ (C-1), 117.2 (C-5/C-3), 42.8 (C-5'); Anal. Calcd. For $\mathrm{C}_{15} \mathrm{H}_{14} \mathrm{~N}_{2} \mathrm{O}_{3}$ : C, 66.66; $\mathrm{H}, 5.22 ; \mathrm{N}, 10.36$. Found: C, 66.74; H, 5.36; N, 10.29.

N-(Benzyl carbamoyl)-2-hydroxy-3-methylbenzamide $\mathbf{2 3 b}$. 8-Methyl-2H-benz[e]-1,3-oxazin-2,4(3H)-dione 22b was allowed to react with benzyl amine according to general procedure $\mathrm{G}$ to give $\mathbf{2 3 \mathbf { b }}$ which was recrystallised from ethanol (65\% yield), $\mathrm{mp} 220-223^{\circ} \mathrm{C} . v_{\max }(\mathrm{KBr}) / \mathrm{cm}^{-1} 3337-2946$ $(\mathrm{O}-\mathrm{H}), 3249(\mathrm{~N}-\mathrm{H}), 1696(\mathrm{C}=\mathrm{O}), 1642(\mathrm{C}=\mathrm{O}) ;{ }^{1} \mathrm{H}$ NMR $\left(200 \mathrm{MHz}, \mathrm{d}_{6}\right.$-DMSO) $\delta 11.30$ (bs, $1 \mathrm{H}, \mathrm{H}-2^{\prime}$ ), 10.70 (bs, $1 \mathrm{H}$, $1-\mathrm{OH}), 8.90\left(\mathrm{t}, 1 \mathrm{H}, J=5.6 \mathrm{~Hz}, 4^{\prime}-\mathrm{NH}\right), 7.80(\mathrm{~d}, 1 \mathrm{H}, J=7.5 \mathrm{~Hz}$, $\mathrm{H}-6), 7.40-7.20(\mathrm{~m}, 6 \mathrm{H}, \mathrm{ArH}$ and $\mathrm{H}-4), 6.80(\mathrm{t}, 1 \mathrm{H}, J=$ $7.5 \mathrm{~Hz}, \mathrm{H}-5$ ), 7.00-6.90 (m, 2H, H-4 and H-6), 4.60 (d, 2H, $\left.J=5.2 \mathrm{~Hz}, \mathrm{H}-5^{\prime}\right), 2.20\left(\mathrm{~s}, 3 \mathrm{H}, \mathrm{CH}_{3}\right) ;{ }^{13} \mathrm{C} \mathrm{NMR}(50 \mathrm{MHz}$, $\mathrm{d}_{6}$-DMSO) $\delta 167.9\left(\mathrm{C}-1^{\prime}\right), 159.7(\mathrm{C}-2), 154.9\left(\mathrm{C}-3^{\prime}\right), 137.2$ $\left(\mathrm{C}-6^{\prime}\right), 135.0$ (C-4), $128.4\left(\mathrm{C}-8^{\prime}\right), 127.3\left(\mathrm{C}-7^{\prime}\right), 127.0\left(\mathrm{C}-9^{\prime}\right)$, 126.3 (C-3), 125.5 (C-6), 119.0 (C-5), 115.1 (C-1), 42.9 (C-5'), $15.9\left(\mathrm{CH}_{3}\right)$; Anal. Calcd. For $\mathrm{C}_{16} \mathrm{H}_{16} \mathrm{~N}_{2} \mathrm{O}_{3}$ : C, 67.59; $\mathrm{H}, 5.67$; N, 9.85. Found: C, 67.64; H, 5.54; N, 9.87.

N-(Benzyl carbamoyl)-4-ethoxy-2-hydroxybenzamide 23c. 7-Ethoxy-2H-benz[e]-1,3-oxazin-2,4(3H)-dione 22d was allowed to react with benzyl amine according to general procedure $\mathrm{F}$ to give $23 \mathrm{c}$ which was recrystallised from ethanol $(70 \%$ yield $), \mathrm{mp} 204-206^{\circ} \mathrm{C}$. $\nu_{\max }(\mathrm{KBr}) / \mathrm{cm}^{-1} 3333-$ $2876(\mathrm{O}-\mathrm{H}), 3225-3156(\mathrm{~N}-\mathrm{H}), 1692(\mathrm{C}=\mathrm{O}), 1650(\mathrm{C}=\mathrm{O})$; ${ }^{1} \mathrm{H}$ NMR (200 MHz, d 6 -DMSO) $\delta 11.90$ (bs, $1 \mathrm{H}, \mathrm{H}-2^{\prime}$ ), 10.20 (bs, $1 \mathrm{H}, 2-\mathrm{OH}), 8.00\left(\mathrm{t}, 1 \mathrm{H}, J=5.4 \mathrm{~Hz}, 4^{\prime}-\mathrm{NH}\right), 7.90(\mathrm{~d}, 1 \mathrm{H}$, $J=8.9 \mathrm{~Hz}, \mathrm{H}-6), 7.30(\mathrm{~m}, 5 \mathrm{H}, \mathrm{ArH}), 6.60\left(\mathrm{dd}, 1 \mathrm{H}, J_{\mathrm{H}-5, \mathrm{H}-3}=\right.$ $\left.2.6 \mathrm{~Hz}, J_{\mathrm{H}-5, \mathrm{H}-6}=8.9 \mathrm{~Hz}, \mathrm{H}-5\right), 6.50(\mathrm{~d}, 1 \mathrm{H}, J=2.2 \mathrm{~Hz}, \mathrm{H}-3)$, $4.40\left(\mathrm{~d}, 2 \mathrm{H}, J=6.0 \mathrm{~Hz}, \mathrm{H}-5^{\prime}\right), 4.10\left(\mathrm{q}, 2 \mathrm{H}, J=6.8 \mathrm{~Hz}, \mathrm{CH}_{2}-\mathrm{O}\right)$, $1.30\left(\mathrm{t}, 3 \mathrm{H}, J=6.8 \mathrm{~Hz}, \mathrm{CH}_{3}\right) ;{ }^{13} \mathrm{C}$ NMR $\left(50 \mathrm{MHz}, \mathrm{d}_{6}-\mathrm{DMSO}\right)$ $\delta 166.1\left(\mathrm{C}-1^{\prime}\right), 160.7(\mathrm{C}-4), 158.9(\mathrm{C}-2), 153.2\left(\mathrm{C}-3^{\prime}\right), 137.2$ $\left(\mathrm{C}-6^{\prime}\right), 132.4(\mathrm{C}-6), 128.4\left(\mathrm{C}-8^{\prime}\right), 127.3\left(\mathrm{C}-7^{\prime}\right), 127.0\left(\mathrm{C}-9^{\prime}\right)$, 110.5 (C-5), 109.4 (C-1), 101.7 (C-3), $64.6\left(\mathrm{CH}_{2}-\mathrm{O}\right), 42.8$ $\left(\mathrm{C}-5^{\prime}\right), 14.5\left(\mathrm{CH}_{3}\right)$; Anal. Calcd. For $\mathrm{C}_{17} \mathrm{H}_{18} \mathrm{~N}_{2} \mathrm{O}_{4}$ : C, 64.96; H, 5.77; N, 8.91. Found: C, 65.03; H, 5.82; N, 8.84.
$N$-(Benzyl carbamoyl)-2,4-dihydroxybenzamide 23d. 7-Hydroxy-2H-benz[e]-1,3-oxazin-2,4(3H)-dione 22e was allowed to react with benzyl amine according to general procedure $\mathrm{G}$ and gave 23d which was recrystallised from ethanol (75\% yield), mp $220^{\circ} \mathrm{C} . v_{\max }(\mathrm{KBr}) / \mathrm{cm}^{-1} 3200-2700(\mathrm{O}-\mathrm{H}), 3118$, $3033(\mathrm{~N}-\mathrm{H}), 1692(\mathrm{C}=\mathrm{O}), 1665(\mathrm{C}=\mathrm{O}) ;{ }^{1} \mathrm{H}$ NMR $(200 \mathrm{MHz}$, $\mathrm{d}_{6}$-DMSO) $\delta 9.00\left(\mathrm{t}, 1 \mathrm{H}, J=5.6 \mathrm{~Hz}, 4^{\prime}-\mathrm{N}-\mathrm{H}\right), 7.70(\mathrm{~d}, 1 \mathrm{H}, J$ $=7.6 \mathrm{~Hz}, \mathrm{H}-6), 7.30\left(\mathrm{bm}, 6 \mathrm{H}, \mathrm{ArH}, 2^{\prime}-\mathrm{OH}\right), 6.30(\mathrm{~s}, 1 \mathrm{H}, \mathrm{H}-3)$, $6.2(\mathrm{~d}, 1 \mathrm{H}, J=7.6 \mathrm{~Hz}, \mathrm{H}-5), 5.60\left(\mathrm{~m}, 2 \mathrm{H}, 4-\mathrm{OH}\right.$ and $\left.2^{\prime}-\mathrm{NH}\right)$ $4.40\left(\mathrm{~d}, 2 \mathrm{H}, J=6.0 \mathrm{~Hz}, \mathrm{H}-5^{\prime}\right) ;{ }^{13} \mathrm{C} \mathrm{NMR}\left(50 \mathrm{MHz}, \mathrm{d}_{6}-\mathrm{DMSO}\right)$

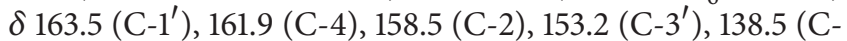
$\left.6^{\prime}\right), 135.3$ (C-6), $128.7\left(\mathrm{C}-8^{\prime}\right), 127.7\left(\mathrm{C}-7^{\prime}\right), 127.5\left(\mathrm{C}-9^{\prime}\right), 109.2$

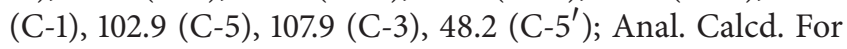
$\mathrm{C}_{15} \mathrm{H}_{14} \mathrm{~N}_{2} \mathrm{O}_{4}$ : C, 59.59; H, 4,67; N, 9.27. Found: C, 59.88; H, $4.68 ; \mathrm{N}, 9.59$.

N-(Benzyl carbamoyl)-2,4-dihydroxy-3-methylbenzamide 23e. 7-Hydroxy-8-methyl-2H-benz[e]-1,3-oxazin-2,4(3H)dione $22 \mathrm{f}$ was allowed to react with benzylamine according to general procedure $\mathrm{G}$ to give $\mathbf{2 3}$ g which was recrystallised from ethyl acetate $(65 \%$ yield $), \mathrm{mp} 230^{\circ} \mathrm{C} . v_{\max }(\mathrm{KBr}) / \mathrm{cm}^{-1}$ 3381, $3225(\mathrm{O}-\mathrm{H}), 3020-2800(\mathrm{~N}-\mathrm{H}), 1687(\mathrm{C}=\mathrm{O}), 1639$ $(\mathrm{C}=\mathrm{O}) ;{ }^{1} \mathrm{H}$ NMR $\left(200 \mathrm{MHz}, \mathrm{d}_{6}\right.$-DMSO) $\delta 11.00(\mathrm{bs}, 1 \mathrm{H}$, $\left.2^{\prime}-\mathrm{NH}\right), 9.80$ (bs, $\left.1 \mathrm{H}, 2-\mathrm{OH}\right), 8.5$ (t, $\left.1 \mathrm{H}, J=5.6 \mathrm{~Hz}, 4^{\prime}-\mathrm{NH}\right)$, $7.5(\mathrm{~d}, 1 \mathrm{H}, J=8.8 \mathrm{~Hz}$; H-5), $7.4(\mathrm{bm}, 5 \mathrm{H}, \mathrm{ArH}), 6.9$ (d, $1 \mathrm{H}$, $J=8.8 \mathrm{~Hz} ; \mathrm{H}-6), 4.50\left(\mathrm{~d}, 2 \mathrm{H}, J=6.0 \mathrm{~Hz}, \mathrm{H}-5^{\prime}\right), 2.00(\mathrm{~s}$, $\left.3 \mathrm{H}, \mathrm{CH}_{3}\right) ;{ }^{13} \mathrm{C}$ NMR (50 MHz, d $\mathrm{d}_{6}$ DMSO) $\delta 165.2\left(\mathrm{C}-1^{\prime}\right)$, 162.9 (C-4), 159.3 (C-2), $157.2\left(\mathrm{C}-3^{\prime}\right), 137.5\left(\mathrm{C}-6^{\prime}\right), 128.7$ $\left(\mathrm{C}-8^{\prime}\right), 127.7\left(\mathrm{C}-7^{\prime}\right), 127.5\left(\mathrm{C}-9^{\prime}\right), 127.3$ (C-6), 112.2 (C-1), 110.9 (C-3), 107.9 (C-5), $44.2\left(\mathrm{C}-5^{\prime}\right), 8.6\left(3-\mathrm{CH}_{3}\right)$; Anal. Calcd. For $\mathrm{C}_{16} \mathrm{H}_{16} \mathrm{~N}_{2} \mathrm{O}_{4}$ : C, 63.99; $\mathrm{H}, 5.37 ; \mathrm{N}, 9.33$. Found: C, 63.88; H, $5.68 ; \mathrm{N}, 9.59$.

4-Acetamido-2-hydroxy-N-(phenylcarbamoyl)benzamide $23 f$. $\mathrm{N}$-(2,4-Dioxo-3,4-dihydro-2H-benz[e][1,3] oxazin-7-yl) acetamide $22 \mathrm{~g}$ was allowed to react with benzyl amine according to general procedure $\mathrm{G}$. The resulting solid was filtered and recrystallised from ethanol to give $23 f(0.25 \mathrm{~g}$, 76\% $\mathrm{mp} 257-$ $260^{\circ} \mathrm{C} . v_{\max }(\mathrm{KBr}) / \mathrm{cm}^{-1} 3500-3200(\mathrm{OH}), 3281,3122(\mathrm{NH})$, 1694, 1664 (C=O), 1613, 1559 (C=C); ${ }^{1} \mathrm{H}$ NMR $(200 \mathrm{MHz}$, $340 \mathrm{~K}, \mathrm{~d}_{6}$-DMSO) $\delta 11.63$ (bs, 1H, 10-NH), 10.24, 10.06 (15$\mathrm{NH}, 2-\mathrm{OH}),\left(\mathrm{s}, 1 \mathrm{H}, J_{\mathrm{H} 10, \mathrm{H} 11}=5.4 \mathrm{~Hz}, 10-\mathrm{NH}\right), 7.84(\mathrm{~d}, 1 \mathrm{H}$, $\left.J_{\mathrm{H} 6, \mathrm{H} 5}=8.8 \mathrm{~Hz}, \mathrm{H}-6\right), 7.58\left(\mathrm{~d}, 1 \mathrm{H}, J_{\mathrm{H} 3, \mathrm{H} 5}=1.8 \mathrm{~Hz}, \mathrm{H}-3\right), 7.38-$ $7.24(\mathrm{~m}, 5 \mathrm{H}, \mathrm{ArH}, \mathrm{H}-13, \mathrm{H}-14, \mathrm{H}-15), 7.03\left(\mathrm{dd}, J_{\mathrm{H} 5, \mathrm{H} 6}=8.8 \mathrm{~Hz}\right.$, $\left.J_{\mathrm{H} 5, \mathrm{H} 3}=1.8 \mathrm{~Hz}, \mathrm{H}-3\right), 4.45\left(\mathrm{~d}, 2 \mathrm{H}, J_{\mathrm{H} 11, \mathrm{H} 10}=5.9 \mathrm{~Hz}, \mathrm{H}-11\right), 2.07$ (s, 3H, H-17); ${ }^{13} \mathrm{C}$ NMR (50 MHz, $300 \mathrm{~K}, \mathrm{~d}_{6}$-DMSO) $\delta 168.7$ (C-16), 165.7 (C-7), 157.5 (C-2), 152.9 (C-9), 144.6 (C-4), 138.8 (C-12), 131.1 (C-6), 128.1, 126.9, 126.7 (C-14, C-13, C-15), 111.2 (C-1), 110.5 (C-5), 106.1 (C-3), 42.6 (C-11), 23.9 (C-17); Anal. Calcd. For $\mathrm{C}_{17} \mathrm{H}_{17} \mathrm{~N}_{3} \mathrm{O}_{4}$ : C, 62.38; $\mathrm{H}, 5.23 ; \mathrm{N}, 12.84$. Found: C, $62.44 ; \mathrm{H}, 5.28 ; \mathrm{N}, 12.90$.

4-Amino-N-(benzyl carbamoyl)-2-hydroxybenzamide 23g. 7Amino-2H-benz[e][1,3] oxazine-2,4(3H)-dione $\mathbf{2 2 h}$ was allowed to react with benzylamine for $16 \mathrm{~h}$ in slight modification to general procedure G. The resulting solid was filtered and recrystallised from toluene to give $23 \mathrm{~g}(0.15 \mathrm{~g}$, $54 \%$ ) as light brown solid, mp $208-211^{\circ} \mathrm{C}$ decomp. $\nu_{\max }(\mathrm{KBr})$ $\mathrm{cm}^{-1}$ 3500-3200(OH), 3489, 3390, $3330(\mathrm{NH}), 16861645$ 
$(\mathrm{C}=\mathrm{O}) ;{ }^{1} \mathrm{H}$ NMR $\left(200 \mathrm{MHz}, 340 \mathrm{~K}, \mathrm{~d}_{6}\right.$-DMSO) $\delta 10.18$ (bs, $1 \mathrm{H}, 2-\mathrm{OH}), 9.00\left(\mathrm{t}, 1 \mathrm{H}, J_{\mathrm{H} 10, \mathrm{H} 11}=5.1 \mathrm{~Hz} 10-\mathrm{NH}\right), 7.65(\mathrm{~d}, 1 \mathrm{H}$, $\left.J_{\mathrm{H} 6, \mathrm{H} 5}=8.6 \mathrm{~Hz}, \mathrm{H}-6\right), 7.34-7.27$ (m, 6H, Ar, H-13, H-14, H-15 and $8-\mathrm{NH}$ exchangeable with $\left.\mathrm{D}_{2} \mathrm{O}\right), 6.19-6.11(\mathrm{~m}, 2 \mathrm{H}, \mathrm{H}-5$ and $\mathrm{H}-3), 5.88\left(\mathrm{bs}, 2 \mathrm{H}, 4-\mathrm{NH}_{2}\right), 4.42\left(\mathrm{~d}, 2 \mathrm{H}, J_{\mathrm{H} 11, \mathrm{H} 10}=5.1 \mathrm{~Hz}\right.$, $\mathrm{H}-11) ;{ }^{13} \mathrm{C}$ NMR (50 MHz, $300 \mathrm{~K}, \mathrm{~d}_{6}$-DMSO) $\delta 166.6$ (C-7), 159.4 (C-2), 154.8, 153.3 (C-4,C-9), 139.0 (C-12), 131.7 (C-6), 128.0 (C-14), 126.9, 126.6 (C-15, C-12), 106.6 (C-5), 105.5 (C-1), 99.2 (C-3), 42.5 (C-11); Anal. Calcd. For $\mathrm{C}_{15} \mathrm{H}_{15} \mathrm{~N}_{3} \mathrm{O}_{3}$ : C, 63.15; H, 5.30; N, 14.73. Found: C, 62.78; H, 4.90; N, 14.30.

\subsection{Antibacterial Assays}

4.2.1. Determination of Minimal Inhibitory Concentrations (MICs) of Novel Compounds. Minimal inhibitory concentrations (MICs) were determined on 7 different bacterial and 4 fungi cultures. The bacteria include Escherichia coli (FB5), Acinetobacter baumannii (ATCC19606), Pseudomonas aeruginosa (PAO9503), Staphylococcus aureus (FB13), Bacillus subtilis (PAO9503), Streptococcus agalactiae (FB31) Mycobacterium smegmatis (CON 21), and Mycobacterium chlorophenolicum (CON 24). The fungi include Aspergillus niger, Rhizopus oryzae, Absidia corymbifera, and Alternaria alternata. Each one of the different strains of bacteria were cultured into $10 \mathrm{~mL}$ of nutrient broth (NB) or malt extract broth for fungi and incubated overnight at $37^{\circ} \mathrm{C}$ except for Mycobacterium smegmatis at $30^{\circ} \mathrm{C}$ for 24 hours and Mycobacterium chlorophenolicum for 4 days. All fungal cultures were grown at $25^{\circ} \mathrm{C}$ for up to seven days except for Alternaria alternate, 3 days $35^{\circ} \mathrm{C}$. The grown cultures were diluted ( $1 / 10$ in NB or Malt extract broth) and incubated for a further 2 hours (to reach exponential phase) and then used in the MIC assay. Compound stock solutions of $10^{4} \mu \mathrm{g} / \mathrm{mL}$ were made up in DMSO ensuring that a maximum of $30 \mu \mathrm{L}$ is used, otherwise inhibitory effects will be shown on some bacterial/fungal cultures). In sterile microcentrifuge tubes, varying amounts of exponential phase culture $(0.1 \mathrm{~mL})$ were added and $\mathrm{NB}$ $(0.9 \mathrm{~mL})$ to make up a total volume of $1 \mathrm{~mL}$. Each culture was then incubated at $37^{\circ} \mathrm{C}$ overnight. Control tubes were made using DMSO without the addition of compound. At the completion of the incubation, the microcentrifuge tubes containing culture were vortexed and compared to their respective controls (without compound). Compounds which displayed an absence of turbidity lower than $50 \mu \mathrm{g} / \mathrm{mL}$ were subject to further dilutions, while if there is growth (or turbidity) at a particular concentration then the value is recorded as the MIC. The dilution series was carried out in factors of 2 as recommended (i.e., at 200, 100, 50, 25, 12.5, 6.25 , and $3.125 \mu \mathrm{g} \mathrm{mL}^{-1}$ resp.). The MIC was determined by the absence of turbidity at the lowest concentration.

4.2.2. Agar Disk Diffusion Method. Compounds that were insoluble in DMSO or the NB were evaluated for their antimicrobial activity by agar diffusion assays. The surface of an NA or Malt agar plate was flood-inoculated with an overnight $\mathrm{NB}$ or malt broth culture of a particular culture adjusted to $10^{8} \mathrm{CFU} / \mathrm{mL}$ ( $10^{8}$ colony forming units per millimeter). Each disk contained a specific culture and sterile $12.7-\mathrm{mm}$ paper disk (oxide) was placed onto the dry surface for each compound. The insoluble compound was resuspended in DMSO and a $20 \mu \mathrm{L}$ aliquot was impregnated onto the surface of a sterile paper disc including $20 \mu \mathrm{L}$ of DMSO control. The diameter of the zone of inhibition was measured after incubation for $18 \mathrm{hr}$ and compared to the control zone (DMSO).

\section{Conflict of Interests}

The authors do not have any conflict of interests.

\section{References}

[1] C. Foucault and P. Brouqui, "How to fight antimicrobial resistance," FEMS Immunology and Medical Microbiology, vol. 49, no. 2, pp. 173-183, 2007.

[2] H. C. Neu, "The crisis in antibiotic resistance," Science, vol. 257, no. 5073, pp. 1064-1073, 1992.

[3] R. Wise, T. Hart, O. Cars et al., "Antimicrobial resistance," British Medical Journal, vol. 317, no. 7159, pp. 609-610, 1998.

[4] J. B. Chylińska, M. Janowiec, and T. Urbański, "Antibacterial activity of dihydro-1,3-oxazine derivatives condensed with aromatic rings in positions 5,6," British Journal of Pharmacology, vol. 43, no. 3, pp. 649-657, 1971.

[5] R. E. Stenseth, J. W. Baker, and D. P. Roman, "Substituted 3-phenyl-1,3-benzoxazine-2,4-diones and their bacteriostatic activity," Journal of Medicinal Chemistry, vol. 6, no. 2, pp. 212213, 1963.

[6] R. Selleri, O. Caldini, E. Mura et al., "New derivatives of 2H-1,3-benzoxazine with anti-bacterial activity," ArzneimittelForschung/Drug Research, vol. 15, no. 8, pp. 913-917, 1965.

[7] K. Waisser, L. Kubicová, V. Buchta et al., "In vitro antifungal activity of 3-phenyl-2H-benzoxazine-2, 4(3H)-diones," Folia Microbiologica, vol. 47, pp. 488-492, 2002.

[8] S. C. Sharma, M. P. Swami, and R. C. Sharma, "Nitrogen heterocyclic analogous of cannabinoids. Part-I: synthesis of $6 \mathrm{H}$ indolo[1,2-C][1,3]-benzoxazine systems and evaluation of their biological activities," Journal of the Indian Chemical Society, vol. 60, no. 10, pp. 1002-1004, 1983.

[9] S. Sharma and M. Sharma, "Synthesis of 5H-pyrazolo[2, 3c] $[1,3]$ benzoxazine systems and evaluation of their biological activities," Acta Ciencia Indica, Series Chemistry, vol. 12, pp. 113$116,1986$.

[10] T. Haneishi, T. Okazaki, T. Hata, C. Tamura, and M. Nomura, "Oxazinomycin, a new carbon-linked nucleoside antibiotic," Journal of Antibiotics, vol. 24, no. 11, pp. 797-799, 1971.

[11] A. Al-Mousawi, J. Al-Rawi, and M. Al-Ajiely M, "Synthesis and antimicrobial activity of 2-substituted-7-chloro-pyrano[3, 4-e][1,3] oxazine-4, 5-dione," The Arab Gulf Journal of Scientific Research, vol. 9, pp. 1-8, 1991.

[12] L. J. Rashan, J. M. A. Al-Rawi, M. T. Nadir, and L. Awni, "Synthesis and biological evaluation of N-salicyloyl-N-benzyl thiourea and 2,2-dimethyl-4-oxo-6-methoxy benzo-1,3dioxin," Farmaco, vol. 46, no. 5, pp. 677-683, 1991.

[13] J. Stec, Q. Huang, M. Pieroni et al., "Synthesis, biological evaluation, and structure-activity relationships of $\mathrm{N}$-benzoyl2-hydroxybenzamides as agents active against $P$. falciparum (K1 strain), trypanosomes, and leishmania," Journal of Medicinal Chemistry, vol. 55, no. 7, pp. 3088-3100, 2012. 
[14] M. D. Silva, C. M. S. Menezes, E. I. Ferreira et al., “Topliss method in the optimization of salicylic acid derivatives as potential antimycobacterial agents," Chemical Biology and Drug Design, vol. 71, no. 2, pp. 167-172, 2008.

[15] A. Missir, V. Zota, J. Soare, and I. Chirita, "Investigations on the alcoxybenzoic acid series. 2, 6-dimetoxybenzoid acid thioureids," Farmacia, vol. 32, no. 1, pp. 53-56, 1984.

[16] J. Jirman, J. Kavalek, and V. Machacek, "Preparation of substituted 1-benzoylthioureas by transacylation of 1-acetylthioureas," Sbornik Vedeckych Praci-Vysoka Skola Chemickotechnologicka Pardubice, vol. 50, pp. 101-110, 1987.

[17] T. Wei, L. Xiong, X. Chen, and Y. Zhang, Preparation of $N$-phenyl- $N^{\prime}-(2$-Acetoxybenzoyl) thiourea derivatives as plant growth regulators, WO, 101735129 A, 20100616, 2010.

[18] N. Ohi, B. Aoki, and T. Shinozaki, "Semisynthetic $\beta$-lactam antibiotics. I. Synthesis and antibacterial activity of new ureidopenicillin derivatives having catechol moieties," Journal of Antibiotics, vol. 39, no. 2, pp. 230-241, 1986.

[19] J. Al-Rawi and K. Al-Shahiry, "Synthesis of 4-oxo-2-thioxo-3, 4dihydro-2H, 1, 3- substituted benzoxazine, their ransformation with water, diazomethane, and amines," Asian Journal of Chemistry, vol. 2, pp. 343-350, 1990.

[20] J. M. A. Al-Rawi and K. F. Al-Shahiry, "Carbon-13 chemical shift analysis of 2-thio-3,4-dihydro-2H-1,3-benzoxazine-4-ones and their degradation products with water and amines," Journal of Environmental Science and Health A, vol. 26, no. 8, pp. 13231332, 1991.

[21] R. Gammill, T. Judge, and J. Morris, "Preparation of 2morpholino-1-benzopyran-4-ones and-1, 3-benzoxazin-4-ones as antiatherosclerotic and antithrombotic agents," WO, 9006921, 1990.

[22] K. M. Pritchard, J. M. Al-Rawi, and A. B. Hughes, "Generalized method for the production of 1,3-benzoxazine, 1,3benzothiazine, and quinazoline derivatives from 2-(hydroxy, thio, or amino) aromatic acids using triphenylphosphine thiocyanogen," Synthetic Communications, vol. 35, no. 12, pp. 16011611, 2005.

[23] K. M. Pritchard, J. Al-Rawi, and C. Bradley, "Synthesis, identification and antiplatelet evaluation of 2-morpholino substituted benzoxazines," European Journal of Medicinal Chemistry, vol. 42, no. 9, pp. 1200-1210, 2007.

[24] G. D. Lei, L. X. Li, Z. Y. Lu, and M. G. Xie, "Improved one-pot synthesis of 4,6-dihydroxyisophthalic acid and 2,3dihydroxyterephthalic acid," Chinese Chemical Letters, vol. 16, no. 8, pp. 1039-1042, 2005.

[25] R. Hrdina, M. Hrdinová, L. Burgert, V. Bures, H. Lewandowski, and R. Suláková, "Complex compounds of boric acid, salicylic acid or its derivatives and silver, method of their preparation, and a preparation containing these compounds for killing moulds, fungi and ligniperdous insects," WO, 2008/058490 A1, 2008.

[26] M. A. Rahim, Y. Matsui, T. Matsuyama, and Y. Kosugi, "Regioselective carboxylation of phenols with carbon dioxide," Bulletin of the Chemical Society of Japan, vol. 76, no. 11, pp. 2191-2195, 2003.

[27] Y. Hiroshi, N. Tatsuo, and T. Ikuzo, "Metal salts of aromatic hydroxyl carboxylic acids with substituents," JP19670330, 1970.

[28] G. N. Walker and M. A. Klett, "Synthesis of varied heterocyclic and substituted aryl alkyl secondary amines, related schiff bases, and amides," Journal of Medicinal Chemistry, vol. 9, no. 4, pp. 624-630, 1966.
[29] J. Patole, D. Shingnapurkar, S. Padhye, and C. Ratledge, "Schiff base conjugates of $p$-aminosalicylic acid as antimycobacterial agents," Bioorganic and Medicinal Chemistry Letters, vol. 16, no. 6, pp. 1514-1517, 2006.

[30] S. J. Wadher, N. A. Karande, S. D. Sonawane, and P. G. Yeole, "Synthesis and biological evaluation of schiff base and 4thiazolidinones of amino salicylic acid and their derivatives as an antimicrobial agent," International Journal of ChemTech Research, vol. 1, no. 4, pp. 1303-1307, 2009.

[31] K. N. Scott, "Carbon-13 nuclear magnetic resonance of biologically important aromatic acids. I. Chemical shifts of benzoic acid and derivatives," Journal of the American Chemical Society, vol. 94, no. 24, pp. 8564-8568, 1972.

[32] J. Heppell and j. Al-Rawi, "Functionalisation of quinazolin4-ones part 1: synthesis of novel 7-substituted-2thioxoquinazolin-4-ones from 4-substituted-2-aminobenzoic acidsand $\mathrm{PPh}_{3}(\mathrm{SCN})_{2}, " 2013$.

[33] S. Ihmaid, J. Al-Rawi, and C. Bradley, "Synthesis, structural elucidation and DNA-dependant protein kinase and antiplatelet studies of 2-amino-[5, 6, 7, 8-mono and 7, 8-di-substituted]-1,3benzoxazines," European Journal of Medicinal Chemistry, vol. 45, no. 11, pp. 4934-4946, 2010.

[34] K. M. Pritchard and J. Al-Rawi, "Reaction of Ph3P(SCN)2 with further orthohydroxy carboxylic acid systems, including substituted $\beta$-keto acids: synthesis of novel 2-thio-1,3-oxazines and their subsequent transformation with amines," Synthetic Communications, vol. 38, no. 23, pp. 4076-4096, 2008.

[35] S. K. Ihmaid, J. M. A. Al-Rawi, C. J. Bradley, M. J. Angove, and M. N. Robertson, "Synthesis, DNA-PK inhibition, antiplatelet activity studies of 2-(N-substituted-3-aminopyridine)substituted-1, 3-benzoxazines and DNA-PK and PI3K inhibition, homology modeling studies of 2-morpholino-(7, 8di and 8-substituted)-1, 3-benzoxazines," European Journal of Medicinal Chemistry, vol. 57, pp. 85-10, 2012.

[36] J. M. Andrews, "Determination of minimal inhibitory concentration," Journal of Antimicrobial Chemotherapy, vol. 48, pp. 516, 2001.

[37] R. R. Yocum, J. R. Rasmussen, and J. L. Strominger, “The mechanism of action of penicillin. Penicillin acylates the active site of Bacillus stearothermophilus D-alanine carboxypeptidase," Journal of Biological Chemistry, vol. 255, no. 9, pp. 3977-3986, 1980.

[38] S. Petrovski and V. A. Stanisich, "Embedded elements in the IncP $\beta$ plasmids R772 and R906 can be mobilized and can serve as a source of diverse and novel elements," Microbiology, vol. 157, no. 6, pp. 1714-1725, 2011.

[39] R. C. Schmeltzer, K. E. Schmalenberg, and K. E. Uhrich, "Synthesis and cytotoxicity of salicylate-based poly(anhydride esters)," Biomacromolecules, vol. 6, no. 1, pp. 359-367, 2005. 

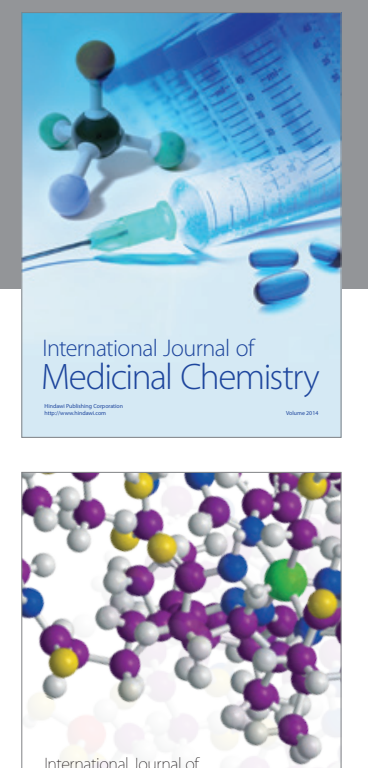

\section{Carbohydrate} Chemistry

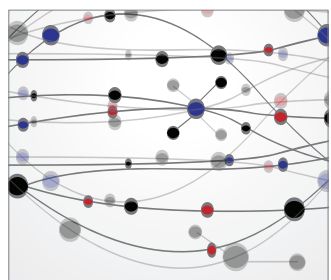

The Scientific World Journal
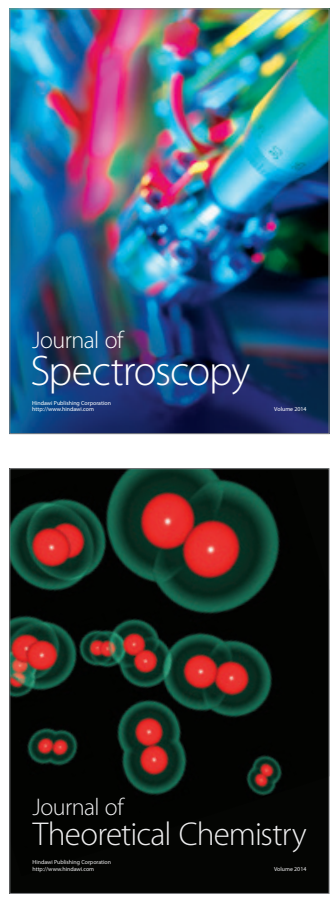
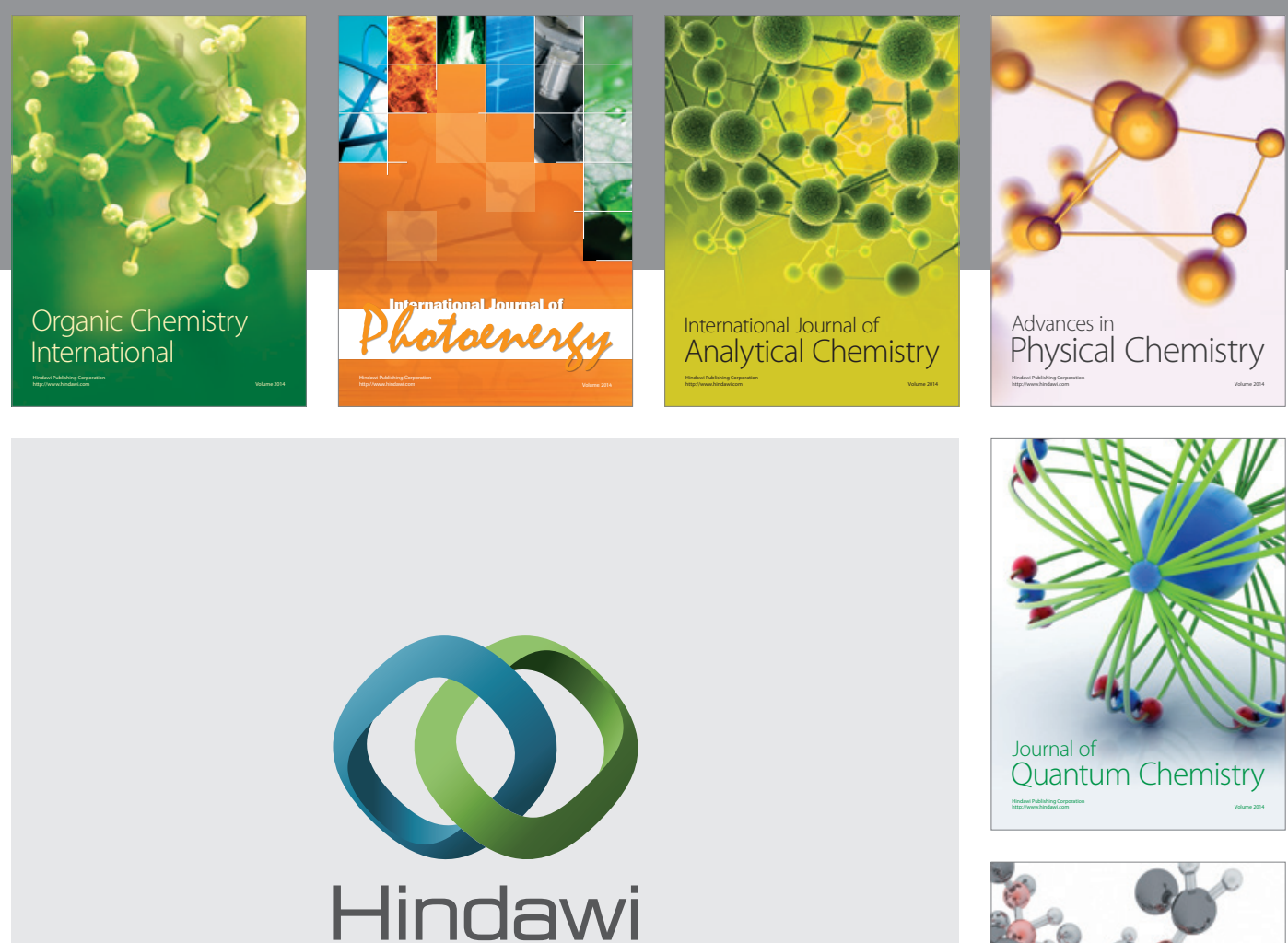

Submit your manuscripts at

http://www.hindawi.com

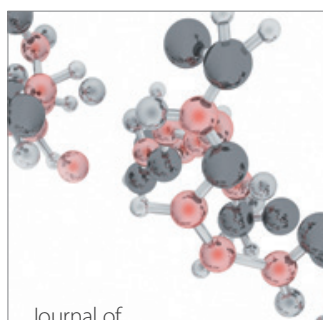

Analytical Methods

in Chemistry

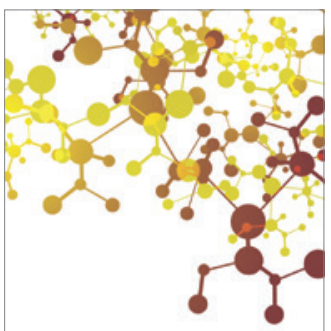

Journal of

Applied Chemistry

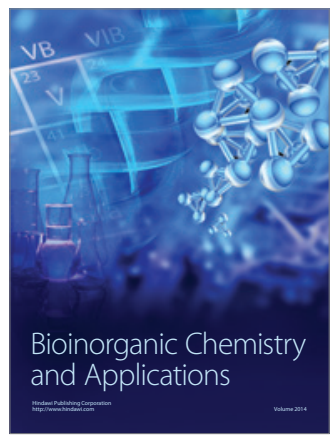

Inorganic Chemistry
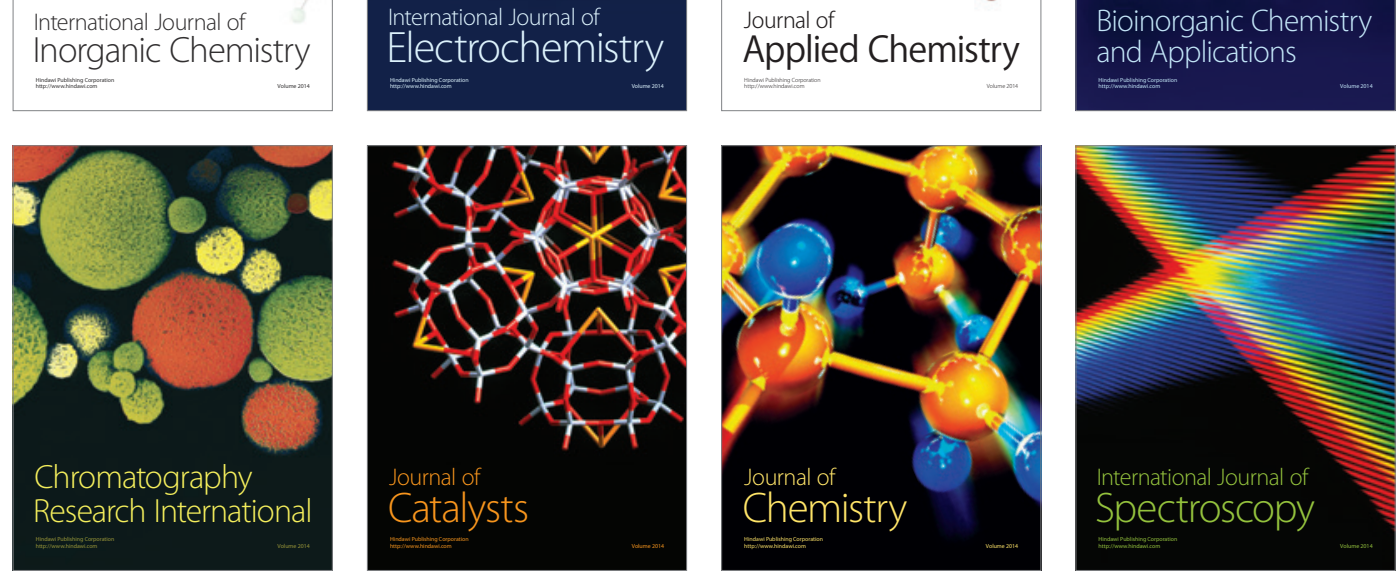